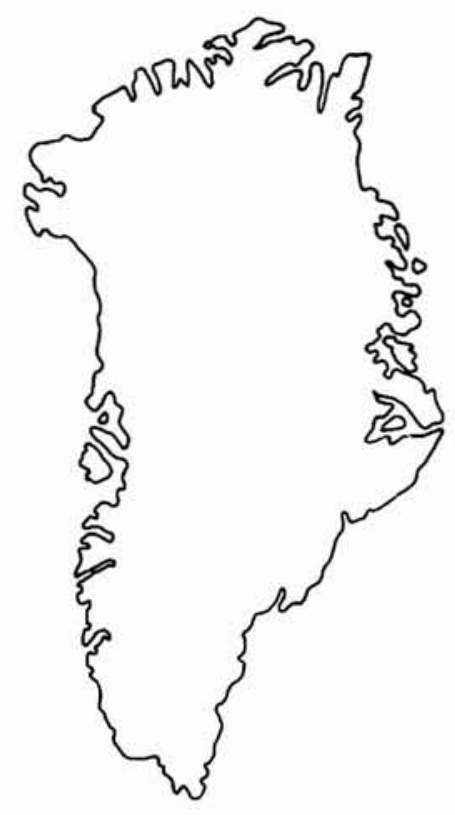

\title{
Lower Palaeozoic Franklinian Basin of North Greenland
}

\author{
A. K. Higgins, Jon R. Ineson, John S. Peel, Finn \\ Surlyk and Martin Sønderholm
}

\begin{abstract}
The Franklinian Basin extends from the Canadian Arctic Islands to eastern North Greenland, a distance of approximately $2000 \mathrm{~km}$. In the North Greenland segment about $8 \mathrm{~km}$ of Lower Palaeozoic strata are well exposed and permit the recognition of 7 stages in the evolution of the basin. With the exception of the first stage of basin initiation, which occurred close to the Precambrian-Cambrian boundary, each stage is differentiated into a southern shelf and slope, and a northern deep-water trough. The position of the boundary between the shelf and trough was probably controlled by deep seated normal faults and, with time, the basin expanded southwards leading to a final foundering of the shelf areas during the Silurian.

The 7 stages in the evolution of the Franklinian Basin in North Greenland are: 1, Late Proterozoic? - Early Cambrian shelf (basin initiation); 2, Early Cambrian carbonate platform and incipient trough; 3, Early Cambrian siliciclastic shelf and turbidite trough; 4, Late Early Cambrian - Middle Ordovician carbonate shelf and starved trough; 5 , Middle Ordovician - Early Silurian aggradational carbonate platform, starved slope and trough; 6, Early Silurian ramp and rimmed shelf, and turbidite trough; 7, Early - Late Silurian drowning of the platform.

Basin evolution and sedimentation patterns in the eastern part of the Franklinian Basin were strongly influenced by the closure of the Iapetus Ocean and Caledonian orogenic uplift in eastern North Greenland. The Franklinian Basin in North Greenland was finally closed in Devonian - Early Carboniferous times, resulting in strong deformation of the northern part of the Franklinian trough sequence during the Ellesmerian Orogeny.
\end{abstract}

A. K. H., J. S. P. \& M. S., Geological Survey of Greenland, Øster Voldgade 10, DK-1350 Copenhagen K, Denmark.

J. R. I., Geological Survey of Denmark, Thoravej 8, DK-2400 Copenhagen NV, Denmark.

F. S., Geological Central Institute, University of Copenhagen, Øster Voldgade 10, DK-1350 Copenhagen K, Denmark.

Lower Palaeozoic strata exposed across North Greenland from Kronprins Christian Land in the east to Washington Land and Inglefield Land in the west (Figs 1-4 and Map 1) form the eastern part of the Franklinian Basin of the Canadian Arctic Islands (cf. Trettin, 1989). Strata assigned to this succession in North Greenland outcrop in an east-west belt almost $1000 \mathrm{~km}$ long, with a maximum preserved north-south width of about 200 $\mathrm{km}$; the sedimentary column attains a thickness of about $8 \mathrm{~km}$. The main part of the succession is of CambrianSilurian age, but the basin probably also contains strata of latest Precambrian and earliest Devonian age.

The Franklinian Basin in North Greenland contains a southern shelf succession and a northern deep-water trough succession, also recognised in adjacent Ellesm- ere Island. Indeed, variations in facies with time show close parallels in the two regions such that lithostratigraphic correlation is often possible across Nares Strait (Troelsen, 1950; Peel \& Christie, 1982; Peel et al., 1982).

A craton composed of Precambrian crystalline basement rocks overlain by late Precambrian sedimentary and volcanic rocks lies to the south of the Franklinian Basin (Sønderholm \& Jepsen, 1991). This is now exposed along the margin of the Inland Ice, and more extensively in eastern North Greenland (Fig. 1). During Early Palaeozoic time this craton was fringed to the north by an east-west trending shallow-marine shelf. Two main facies belts characterise the shelf, a shallowwater carbonate-dominated platform (sensu Schlager, 


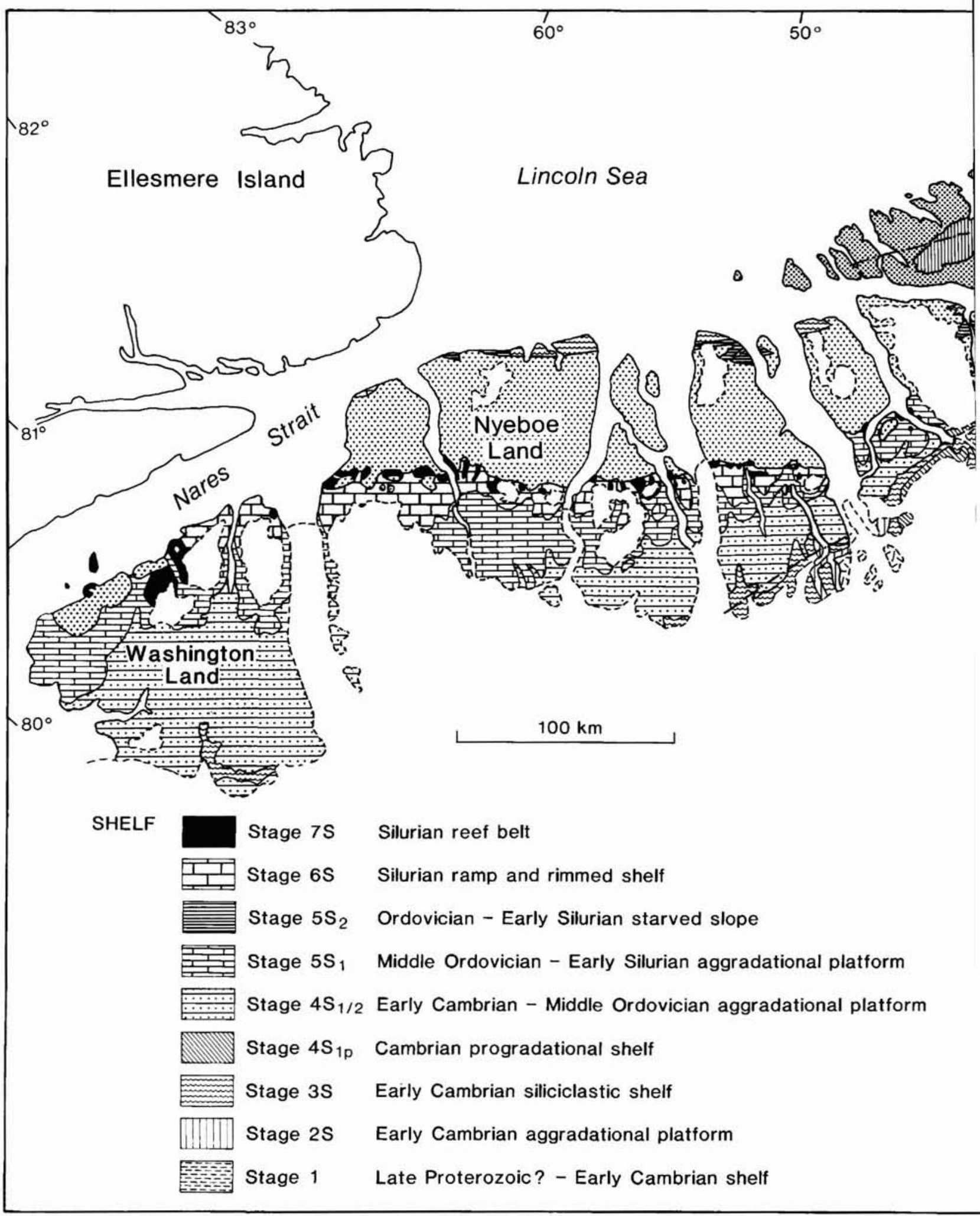

Fig. 1. Geological map showing the subdivision of the Franklinian Basin sequence in North Greenland. See Figs 2-4 and Map 1. HFFZ, Harder Fjord fault zone. 


$\begin{array}{cccc}1 & 1 & \\ 40^{\circ} & 30^{\circ} & 20^{\circ} & 83^{\circ}\end{array}$

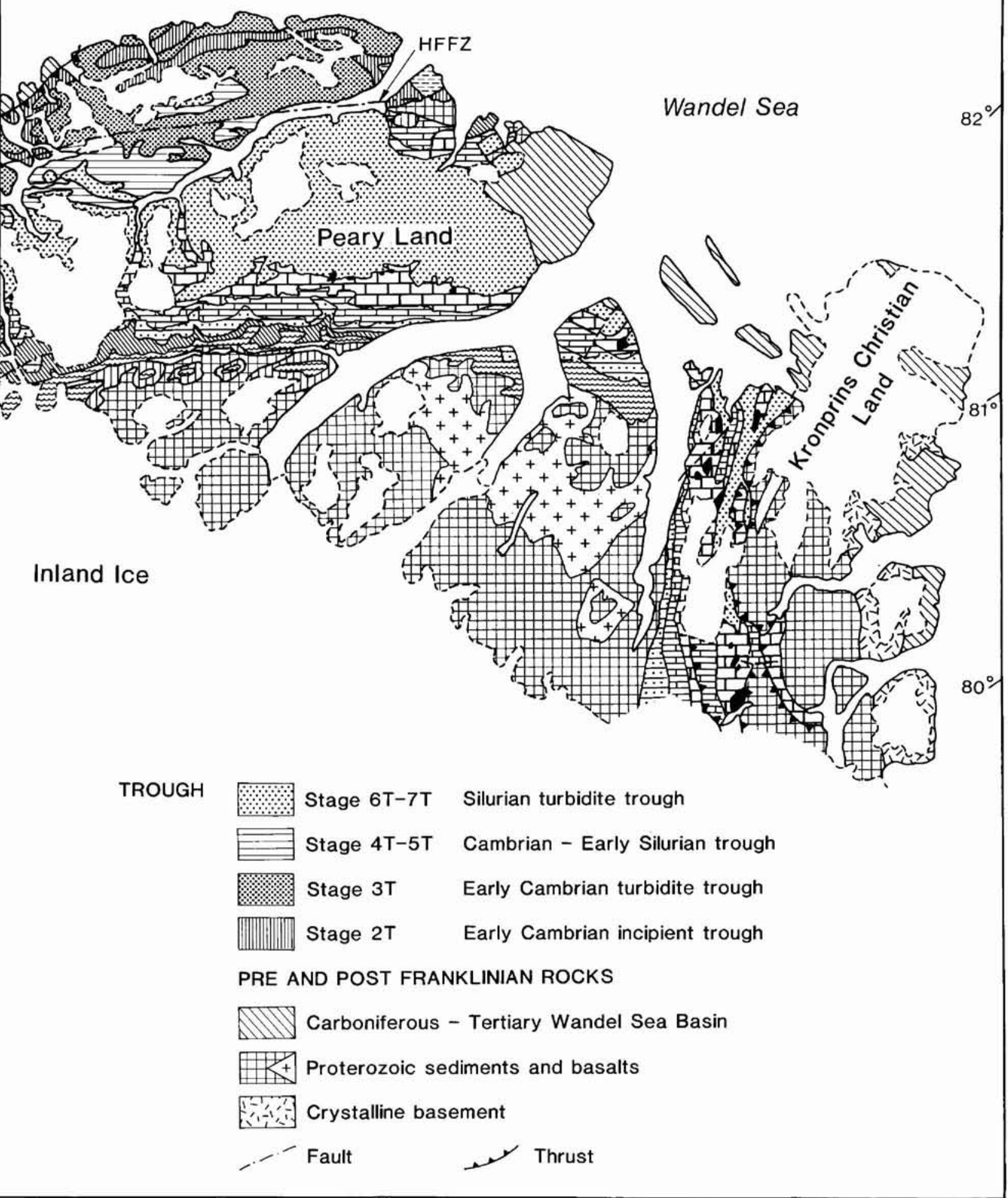




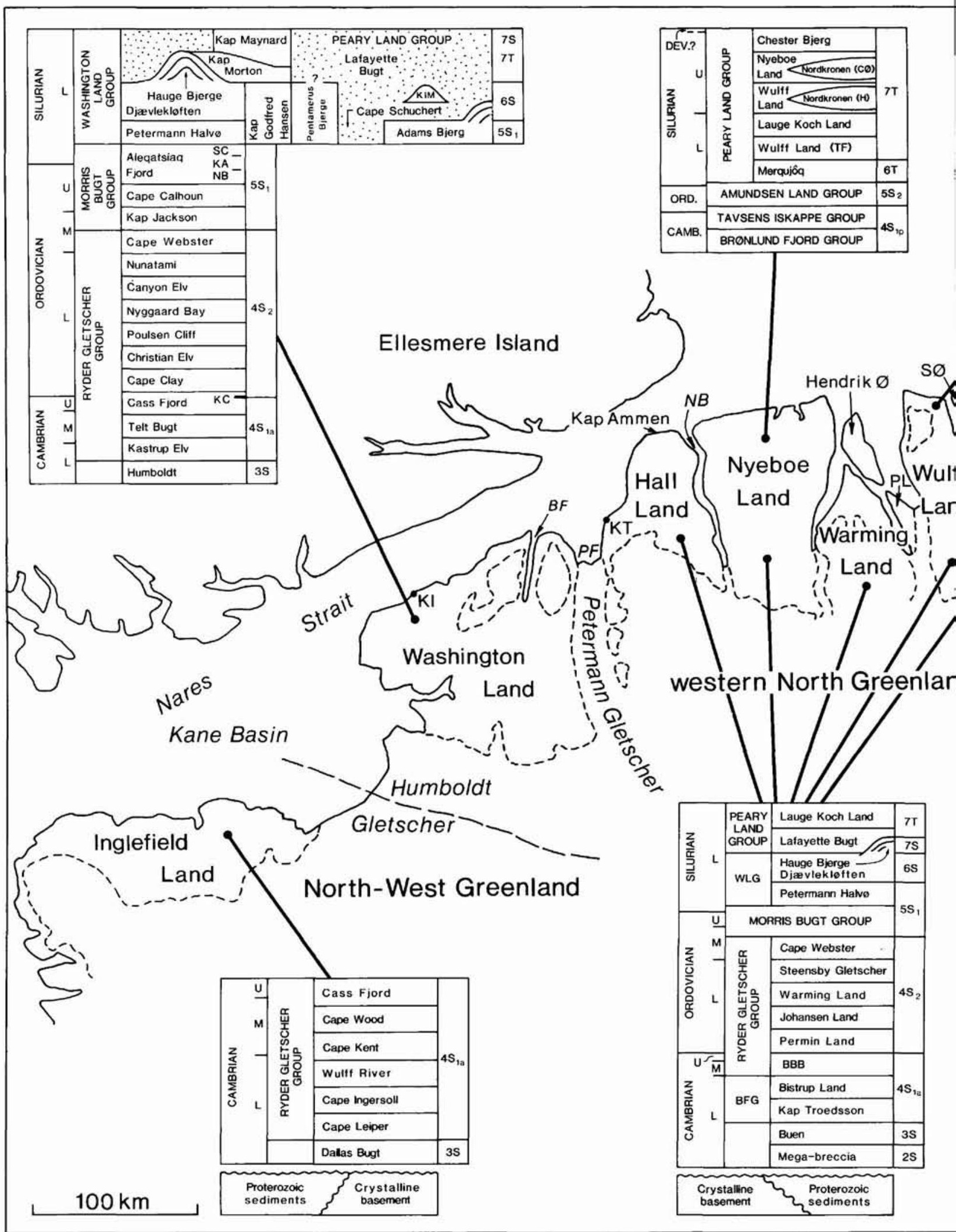




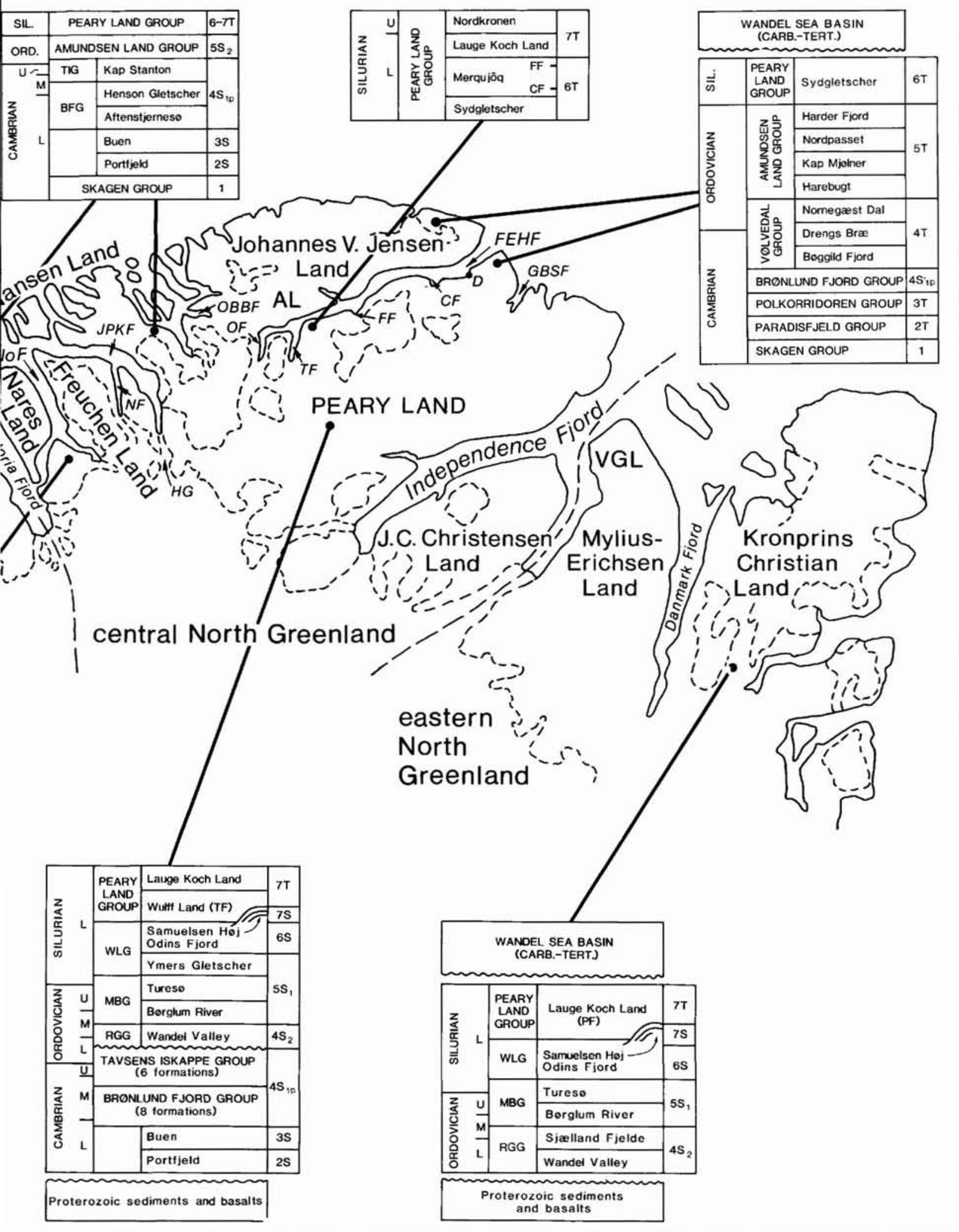


1981), and a shale-dominated shelf. The boundary between these two regimes fluctuated considerably; in some periods the platform was almost drowned, while in others the platform prograded and the platform margin coincided with the shelf-slope break. A deep-water basin, or trough, characterised by deposition of finegrained sediments, sand turbidites, and carbonate conglomerates was situated north of this zone. Shelf-parallel turbidite transport directions suggest that the deepwater basin was two-sided for most of its existence (Surlyk et al., 1980; Surlyk \& Hurst, 1984); for this reason the term trough is used in the following description. There is no direct evidence in North Greenland, however, of a northern margin to the Franklinian Basin.

Deposition in the trough was brought to a close in North Greenland, as in northern Ellesmere Island, by the mid-Palaeozoic Ellesmerian Orogeny. In Greenland this produced the North Greenland fold belt. Deformation is largely confined to the trough succession, and was intense in the extreme north where it was accompanied by low amphibolite facies metamorphism. Deformation decreases southwards, and dies out in a belt of thrusts and monoclines located slightly north of the early Silurian shelf-trough transition.

Due to the remoteness of North Greenland much geological work until recent years has been on a reconnaissance level. Dawes (1971, 1976) has summarised this early work, producing a geological map and synthesis of North Greenland geology. Other reviews are given by Troelsen $(1949,1950)$, Dawes \& Soper (1973), Dawes \& Peel (1981), Dawes \& Christie (1982), Peel (1982a) and Christie \& Dawes (in press; see also Henriksen \& Higgins, 1991).

In 1978-80 and 1984-85 regional systematic mapping and general geological investigations were carried out as part of the North Greenland Project of the Geological Survey of Greenland (GGU; see Henriksen \& Higgins, 1991). The current paper presents a synthesis of the Lower Palaeozoic sedimentary succession in North Greenland, examination of which culminated with the North Greenland Project. An earlier version was given by Higgins et al., in press.

Fig. 2. Stratigraphy of the Franklinian Basin sequence in North Greenland. Individual units are assigned to the stages in basin evolution described in the text; see also Figs 1, 3, 4. AL, Amundsen Land; BBB, Blåfjeld, Brikkerne and Blue Cliffs Formations; BF, Bessels Fjord; BFG, Brønlund Fjord Group; $\mathrm{CF}$, Citronen Fjord, also Citronens Fjord Member; C $\varnothing$, Castle $\emptyset$ Member; D, Depotbugt; FEHF, Frederick E. Hyde Fjord; FF, Freja Fjord, also Freja Fjord Member; GBSF, G. B. Schley Fjord; HG, Henson Gletscher; H, Hendrik Ø Member; JPKF, J. P. Koch Fjord; KA, Kap Ammen Member; KC, Kap
Lower Palaeozoic shelf stratigraphy in North Greenland (Fig. 2) has been described by Christie \& Peel (1977), Fortey \& Peel, 1989; Hurst (1980a, 1984), Ineson \& Peel (1987, in prep.), Peel (1982a, 1985, 1988a, b, 1990), Peel et al. (1981), Peel \& Smith, 1988; Smith et al., 1989; Sønderholm \& Due (1985); Sønderholm et al. (1987) and Sønderholm \& Harland (in prep.).

The lithostratigraphy of the Lower Palaeozoic deepwater succession has been outlined within a framework of six groups by Friderichsen et al., (1982; Fig. 2). Preliminary descriptions of the Cambrian and Ordovician deposits are given by Bengaard et al. (1987), Davis \& Higgins (1987), Higgins et al. (1981), Soper et al. (1980) and Surlyk \& Ineson (1987a). The stratigraphy of the Cambrian-Ordovician deep-water sequence in Peary Land was established by Surlyk et al. (in prep.), while Silurian deep-water stratigraphy was described by Hurst (1980a), Hurst \& Surlyk (1982), Larsen \& Escher $(1985,1987,1991)$ and Surlyk \& Ineson (1987b).

Biostratigraphical and palaeontological studies of the Lower Palaeozoic in North Greenland include: Armstrong (1990), Bjerreskov (1981, 1986, 1989), Conway Morris \& Peel (1990), Fortey \& Peel (1983, 1989, 1990), Grahn \& Nøhr-Hansen (1989), Lane (1972, 1979), McLean (1977), Nøhr-Hansen \& Koppelhus (1988), Norford (1973), Palmer \& Peel (1981), Peel (1979, 1980, 1982b, 1986, 1988a, b, 1990), C. Poulsen (1927, 1934, 1941, 1943, 1958, 1974), V. Poulsen (1964, 1969 , 1974), Robison (1984, 1988), Smith (in press) and Troedsson $(1926,1928)$.

The petroleum geology of the Franklinian Basin in North Greenland is described by Christiansen (1989, 1990).

The main aspects of the tectonic-sedimentological evolution of the Early Palaeozoic shelf sequence in North Greenland were described by Hurst \& Surlyk (1983b). The evolution of the contemporaneous deepwater basin has been related to intrabasinal tectonic lineaments which govern, or influence, the boundaries of the shelf, slope, and trough of the basin at different times (Surlyk \& Hurst, 1983, 1984; Figs 3-5).
Coppinger Member; KI, Kap Independence; KIM, Kap Independence Member; KT, Kap Tyson; MBG, Morris Bugt Group; NB, Newman Bugt, also Newman Bugt Member; NF, Navarana Fjord; NoF, Nordenskiöld Fjord; OBBF, O. B. Bøggild Fjord; OF, Odin Fjord; PF, Profilfjeldet Member; PL, Permin Land; RGG, Ryder Gletscher Group; SC, Store Canyon Member; $₫ \emptyset$, Stephenson $\emptyset$; TF, Thor Fjord, also Thors Fjord Member; VGL, Valdemar Glückstadt Land; WLG, Washington Land Group. 


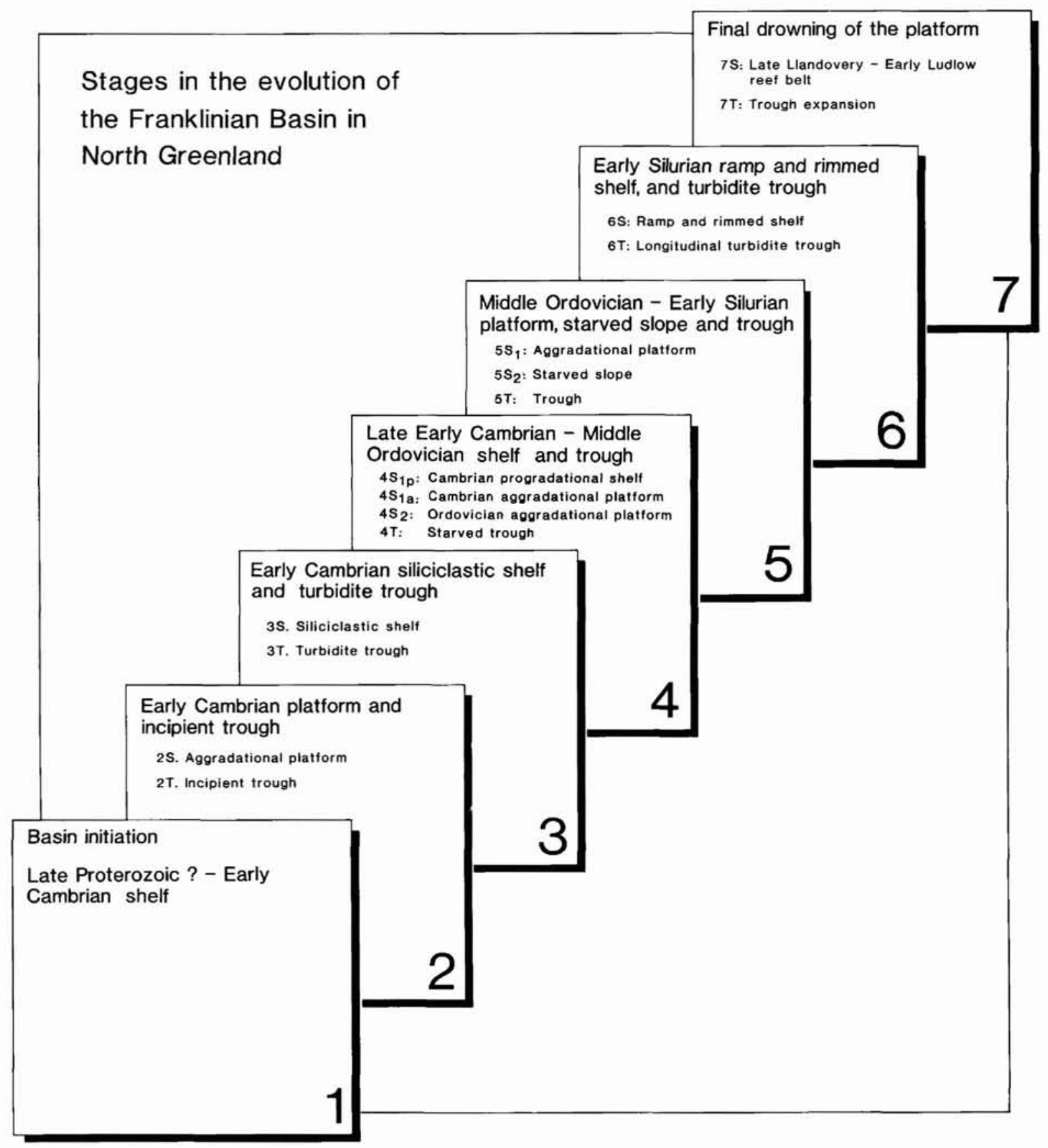

Fig. 3. Stages in the evolution of the Franklinian Basin in North Greenland.

\section{Tectonic lineaments}

The evolution of the North Greenland Early Palaeozoic basin and its differentiation into a southern shelf and a northern trough was interpreted in terms of control by tectonic lineaments by Surlyk et al. (1980), a model elaborated and presented in more detail by Sur- lyk \& Hurst $(1983,1984)$. It is envisaged that the basin expanded in several episodes by southward shift of the southern margin to new E-W trending lineaments. The shifts are accompanied by major changes in sedimentary regimes. This concept is adopted here, permitting the recognition of a number of stages in the evolution of the basin (Figs 3-5). These stages form the basis for the 


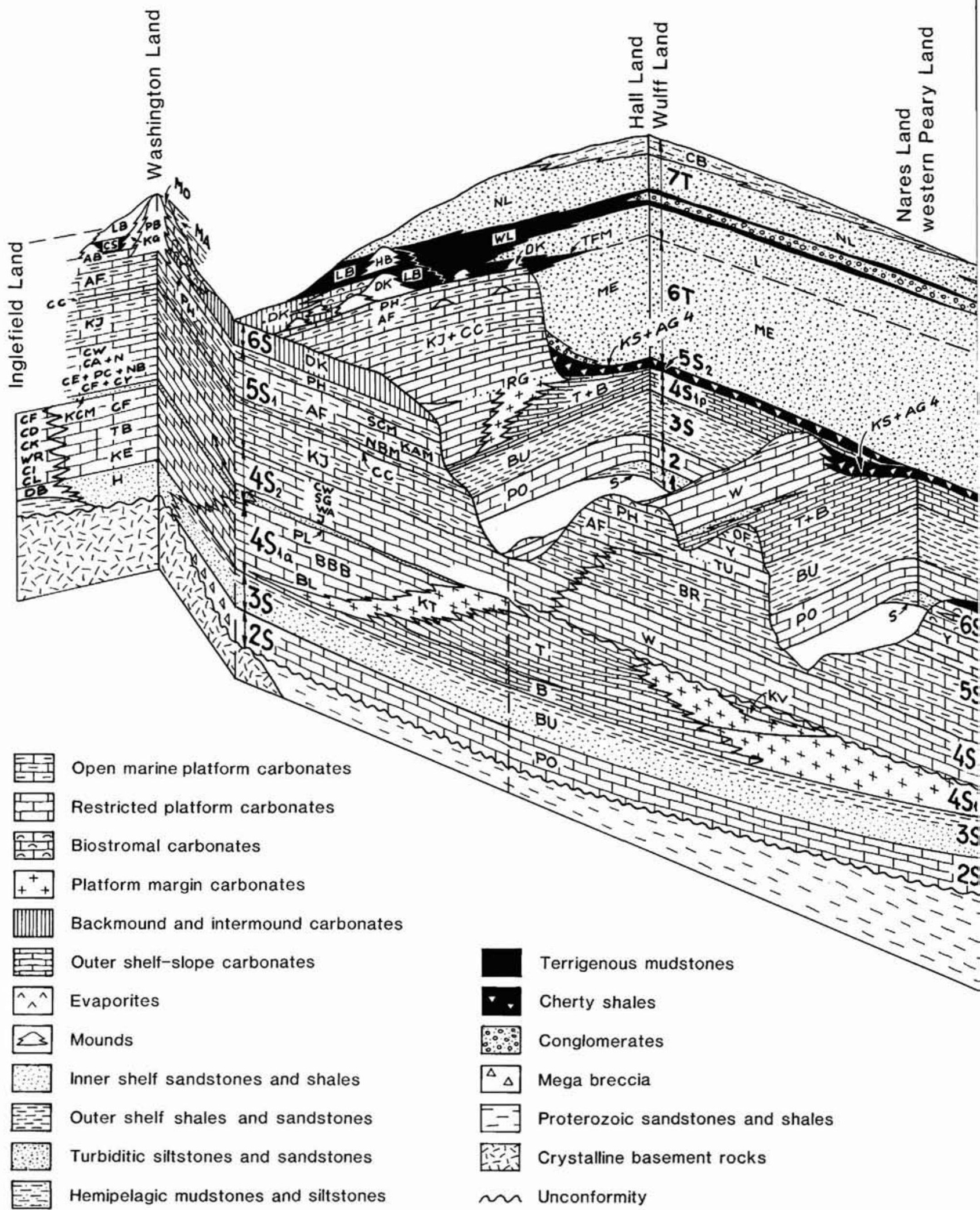




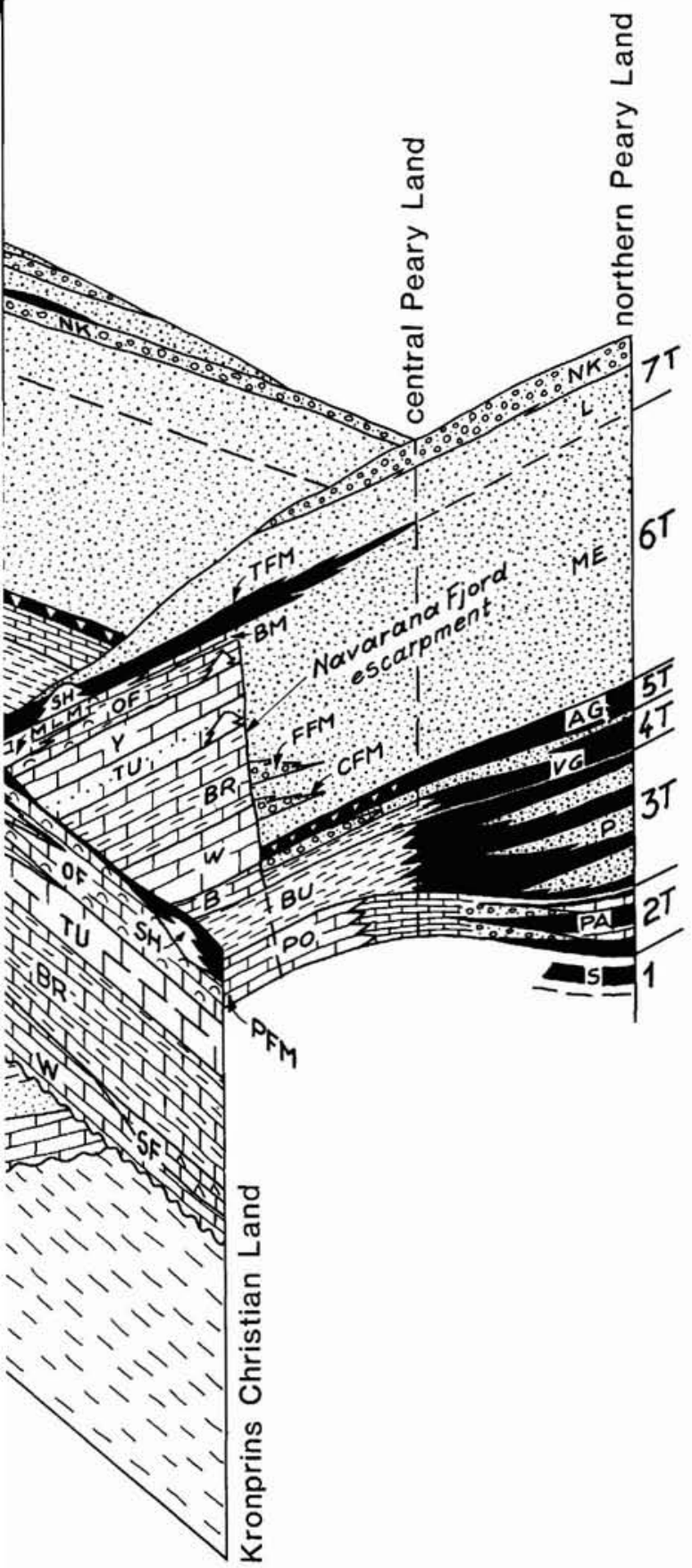

Fig. 4. Fence diagram showing the interpreted relationships of shelf, slope and trough deposits of the various stages in the evolution of the Franklinian Basin sequence of North Greenland (see Figs 1-3). Abbreviations denote formations unless otherwise specified. AB, Adams Bjerg; AF, Aleqatsiaq Fjord; AG, Amundsen Land Group; AG4, unit 4 of Amundsen Land Group; B, Brønlund Fjord Group; BBB, Blåfjeld, Brikkerne and Blue Cliffs Formations; BL, Bistrup Land; BM, Bure Iskappe Member; BR, Børglum River; BU, Buen; CA, Canyon Elv; CB, Chester Bjerg; CC, Cape Calhoun; CD, Cape Wood; CE, Christian Elv; CF, Cass Fjord; CFM, Citronens Fjord Member; CI, Cape Ingersoll; CK, Cape Kent; CL, Cape Leiper; CS, Cape Schuchert; CW, Cape Webster; CY, Cape Clay; DB, Dallas Bugt; DK Djævlekløften; FFM, Freja Fjord Member; H, Humboldt; HB, Hauge Bjerge; J, Johansen Land; KAM, Kap Ammen Member; KCM, Kap Coppinger Member; KE, Kastrup Elv; KG, Kap Godfred Hansen; KJ, Kap Jackson; KS, Kap Stanton; KT, Kap Troedsson; KV, Koch Væg; L, Lauge Koch Land; LB, Lafayette Bugt; MA, Kap Maynard; ME, Merqujôq; MLM, Melville Land Member; MO, Kap Morton; N, Nunatami; NB, Nygaard Bay; NBM, Newman Bugt Member; NK, Nordkronen; NL, Nyeboe Land; OF, Odins Fjord; OI, Offley Island; P, Polkorridoren Group; PA, Paradisfjeld Group; PB, Pentamerus Bjerge; PC, Poulsen Cliff; PFM, Profilfjeldet Member; PH, Petermann Halvø; PL, Permin Land; PO, Portfjeld; RG, Ryder Gletscher Group; S, Skagen Group; SCM, Store Canyon Member; SF, Sjælland Fjelde; SG, Steensby Gletscher; SH, Samuelsen Høj; T, Tavsens Iskappe Group; TB, Telt Bugt; TFM, Thors Fjord Member; TU, Turesø; VG, Vølvedal Group; WA, Warming Land; W, Wandel Valley; WL, Wulff Land; WR, Wulff River; Y, Ymers Gletscher.

integrated description of shelf and trough successions presented in this paper.

Some of the lineaments responsible for control of sedimentation during the Early Palaeozoic are easily defined. The identity of others, however, is not clear, since some of the structures have been shown to be main elements of Ellesmerian thin-skinned thrust zones or Eurekan (Tertiary) fault systems. These later thrusts and faults may have had precursors which were active in the Early Palaeozoic and influenced sedimentation.

The earliest stage of the Franklinian Basin recognised in North Greenland (Skagen Group) is loosely dated as Late Precambrian - Early Cambrian and its base is not known. Later in the Early Cambrian it is possible to define a facies boundary between the shelf carbonates of the Portfjeld Formation and the equivalent trough carbonates of the Paradisfjeld Group (Figs 2-5). This boundary runs from Depotbugt in the east, westwards to outer J. P. Koch Fjord and along the northern coast of Greenland as far as northern Nyeboe Land (Figs 3-5, stage 2). However, the original position of this linea- 


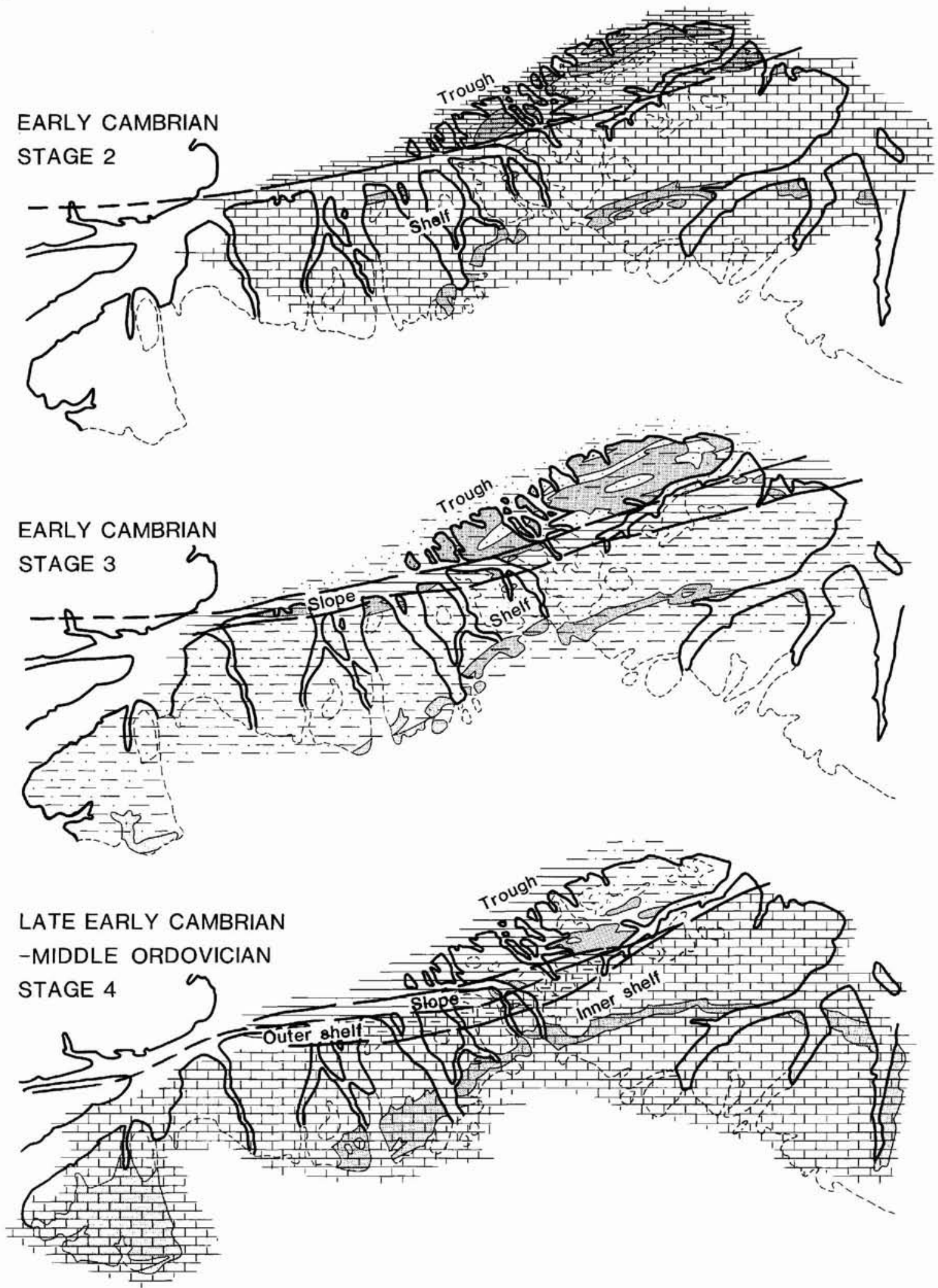

Fig. 5. Stages 2-7 in the evolution of the Franklinian Basin in North Greenland showing the relationships of major sedimentary regimes. The different signatures indicate schematically the distribution of lithologies dominated by carbonate (bricks), sand 


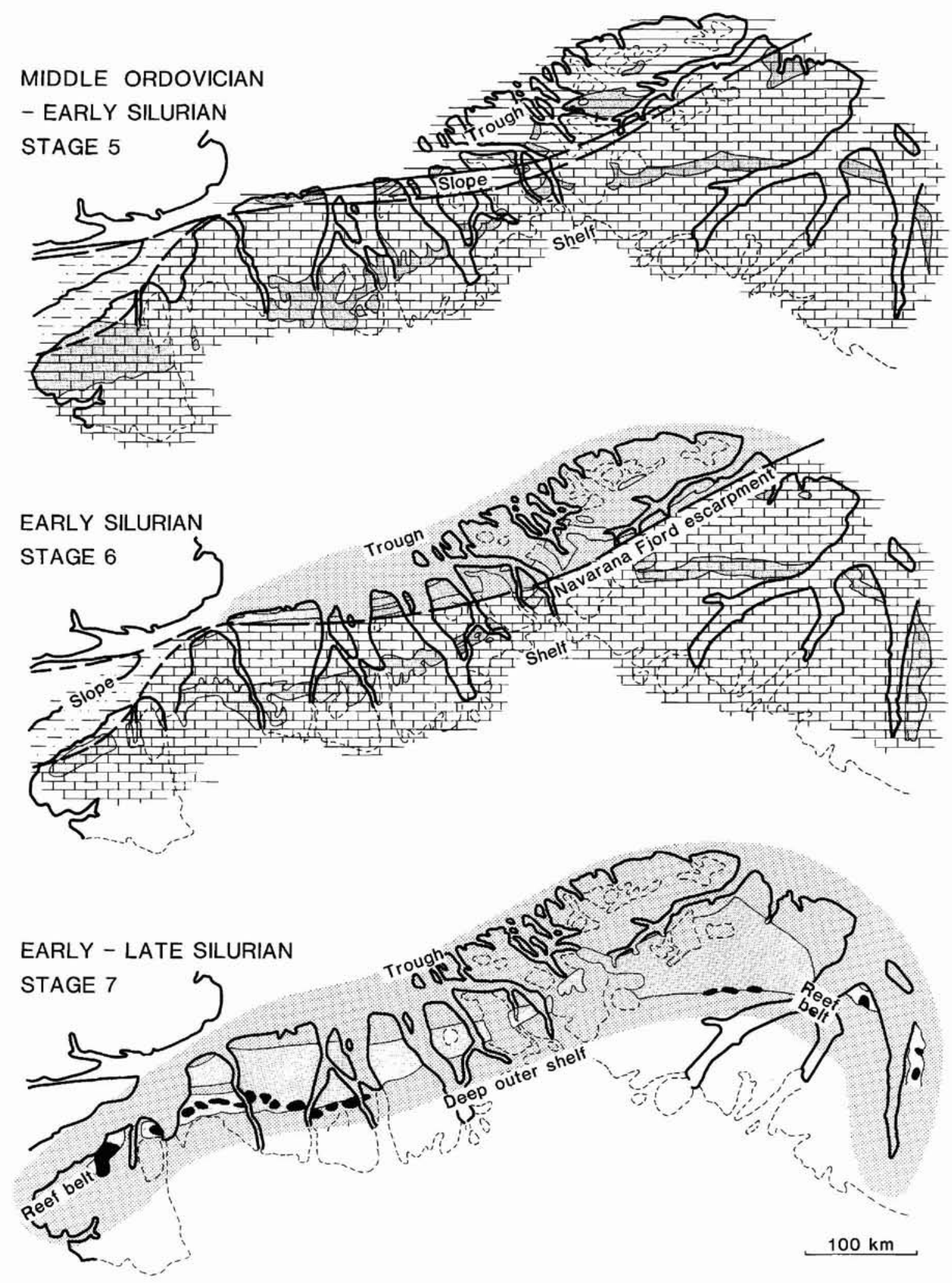

(dots) and mud (horizontal lines). Dense dotting indicates present day exposures. The position of the Navarana Fjord escarpment is shown in stage 6 . 
ment is obscured by the N-S shortening due to Ellesmerian thrusting; it may have been sited farther north, corresponding to a precursor of the present Harder Fjord fault zone (Surlyk et al., 1980; Surlyk \& Hurst, 1984; Soper \& Higgins, 1987). The present distribution of succeeding deposits of the Buen Formation (shelf sandstones and shales) and Polkorridoren Group (trough turbidites) suggests that the shelf margin was located slightly further south (Fig. 5, stage 3); in logged sections deeper water, more offshore facies overlie shallow shelf facies. The original position of the shelf margin lineament, however, is again obscured by Ellesmerian thrusting.

Carbonate platform accumulation resumed on the inner shelf in the late Early Cambrian and continued through the Ordovician, while shale deposition dominated in the outer shelf-slope area which can be characterised as 'starved'. In some areas the total succession deposited on the outer shelf and slope during this period is less than $100 \mathrm{~m}$ thick; $300-500 \mathrm{~m}$ is more normal. The trough deposits, up to $1200 \mathrm{~m}$ thick, are only known from northern Peary Land (Johannes V. Jensen Land) where they include thickly developed turbiditic units of the Vølvedal Group. Two lineaments seem to have determined the boundaries between shelf and trough deposition during this period. The northernmost of these, running from Depotbugt to Nyeboe Land, may have marked the north margin of the shelf during the first part of this period (Fig. 5, stage 4). The turbidites of the Vølvedal Group occur only north of this line. The southern lineament is the Navarana Fjord lineament which is expressed as a platform margin escarpment in the Navarana Fjord - J. P. Koch Fjord area (Figs 4-5, Escher \& Larsen, 1987; Surlyk \& Hurst, 1984; Surlyk \& Ineson, $1987 \mathrm{a}, \mathrm{b}$ ). It extends eastwards to the vicinity of Depotbugt and westwards beneath younger rocks to northern Nyeboe Land and just offshore Hall Land. Carbonate-dominated outer shelf sediments accumulated in the area between the two lineaments during the early part of the period (Fig. 5, stage 4), but these are overlain by deeper water slope or trough sediments (Amundsen Land Group and equivalent chert/shale deposits) suggesting that the basin margin had retreated southwards in the Ordovician to the Navarana Fjord lineament (Fig. 5, stage 5).

In the Late Ordovician and Early Silurian the Navarana Fjord lineament was a major basinal and facies boundary separating shelf carbonate deposition to the south from turbidite deposition of the Peary Land Group to the north (Fig. 5, stage 6). The lineament took the form of a pronounced escarpment and the lowest formations of the turbiditic Peary Land Group (Sydgletscher and Merqujôq Formations) occur only north of the escarpment. In late Llandovery time, the outer platform foundered, probably in response to loading of the trough by the thick turbidite sequences and to orogenic activity in eastern North Greenland. The trough filled to the brim with turbidites and expanded southwards to cover most of what is now North Greenland (Fig. 5, stage 7) (Hurst \& Surlyk, 1982; Hurst et al., 1983; Surlyk \& Hurst, 1984). A new shelf-trough boundary was established farther to the south, corresponding to the line of impressive carbonate mounds running from central Hall Land to Kronprins Christian Land. The shelf was almost totally drowned at about the Llandovery-Wenlock boundary and carbonate deposition only persisted in a few isolated mounds. The succession of formations in the Peary Land Group - Wulff Land Formation (mudstones), Lafayette Bugt Formation (mudstones and carbonate conglomerates), Lauge Koch Land Formation (sandstone turbidites), Nordkronen Formation (mainly turbiditic chert pebble conglomerates) and Chester Bjerg Formation (turbiditic mudstones and siltstones) - reflect facies variations governed by the supply of detritus to the deep-water trough from the source areas in the east, principally the rising mountains of the East Greenland Caledonides (Hurst $\boldsymbol{e t}$ al., 1983; Surlyk, 1982; Surlyk \& Hurst, 1984).

\section{Evolution of the Franklinian Basin in North Greenland}

The development of the Franklinian Basin in North Greenland is described here in terms of 7 stages (Figs 3-5) which are defined on the basis of sedimentary infill, position and structural style of the shelf-trough boundary (cf. Surlyk \& Hurst, 1983, 1984). The stages are broadly analogous to seismic stratigraphic sequences (Mitchum et al., 1977; Vail et al., 1977; Van
Wagoner et al., 1988) or to groups of temporally related depositional systems (e.g. Galloway \& Hobday, 1983). The stages are described below in ascending order; in each stage description of the shelf development is followed by description of the equivalent slope and deepwater trough development. 


\section{Stage 1: Basin initiation, Late Proterozoic? - Early Cambrian shelf}

The oldest representative of the Early Palaeozoic sedimentary cycle is the Skagen Group (Figs 1-4, 6-7). It is recognised in north-east Peary Land, Johannes V. Jensen Land and in northern parts of central and western North Greenland, notably northern Wulff Land (Fig. 6). The base of the group is not seen although stratigraphic relationships in north-east Peary Land suggest that it may rest unconformably on Proterozoic quartzites and volcanics (Christie \& Ineson, 1979). In its northern outcrop in Johannes V. Jensen Land, the Skagen Group is overlain by relatively deep-water carbonates of the Paradisfjeld Group (see stage 2, below) whereas south of Frederick E. Hyde Fjord and in central and western North Greenland, it is overlain by platform carbonates of the Portfjeld Formation. The age of the Skagen Group is uncertain, but an Early Cambrian (Atdabanian) fauna has been collected from the Kennedy Channel Formation of Ellesmere Island (Long, 1989a) from strata considered by Dawes \& Peel (1984) to be equivalent to the Skagen Group of northern Wullf Land.

In its type area in north-east Peary Land the Skagen Group consists of tightly folded quartzitic sandstones and mudstones divided into three units by Friderichsen et al. (1982); the depositional environment is not known, but upper beds of the succession in the G. B. Schley Fjord area include stromatolitic and dessicationcracked dolomites of peritidal origin. The lowest unit comprises structureless quartzitic sandstones, the middle unit dark phyllitic mudstones, and the upper unit consists of thick-bedded quartzitic sandstones with phyllitic mudstone interbeds and rare pebble conglomerates. The upper unit is also exposed on the north side of the mouth of Frederick E. Hyde Fjord where it has a conformable, but highly deformed, contact with the overlying Paradisfjeld Group.

Higgins \& Soper (1985) suggested similarities between the Skagen Group and the siliciclastic sequence which underlies the Portfjeld Formation between northern Wulff Land and J. P. Koch Fjord. This sequence is included in the Skagen Group (Surlyk \& Ineson, 1987a). In northern Wulff Land, where deformation is less intense, the Skagen Group consists of over $500 \mathrm{~m}$ of mudstones, sandstones and dolomites. The lower half of the group is dominated by mudstones with thin, crosslaminated, fine-grained to medium-grained sandstones. Sandstone bed thickness increases upwards and hummocky cross-stratification becomes more common towards the middle of the group. This lower interval records sedimentation on an offshore, storm-influenced shelf. It is succeeded by a more varied sequence of coarse pebbly sandstones, hummocky cross-stratified sandstones, mudstones and intraclastic oolitic dolomites, reflecting shallow-water, inshore environments. The coarse sandstones show large-scale trough crossbedding and parallel, even lamination of storm-dominated shoreface and possibly beach origin. Grey, hummocky cross-stratified oolitic-intraclastic dolomites

Fig. 6. Mudstones, sandstones and dolomites of the Skagen Group (S, stage 1) overlain by a $340 \mathrm{~m}$ thick sequence of light coloured Portfjeld Formation dolomites (PO, stage 2S), northern Wulff Land.

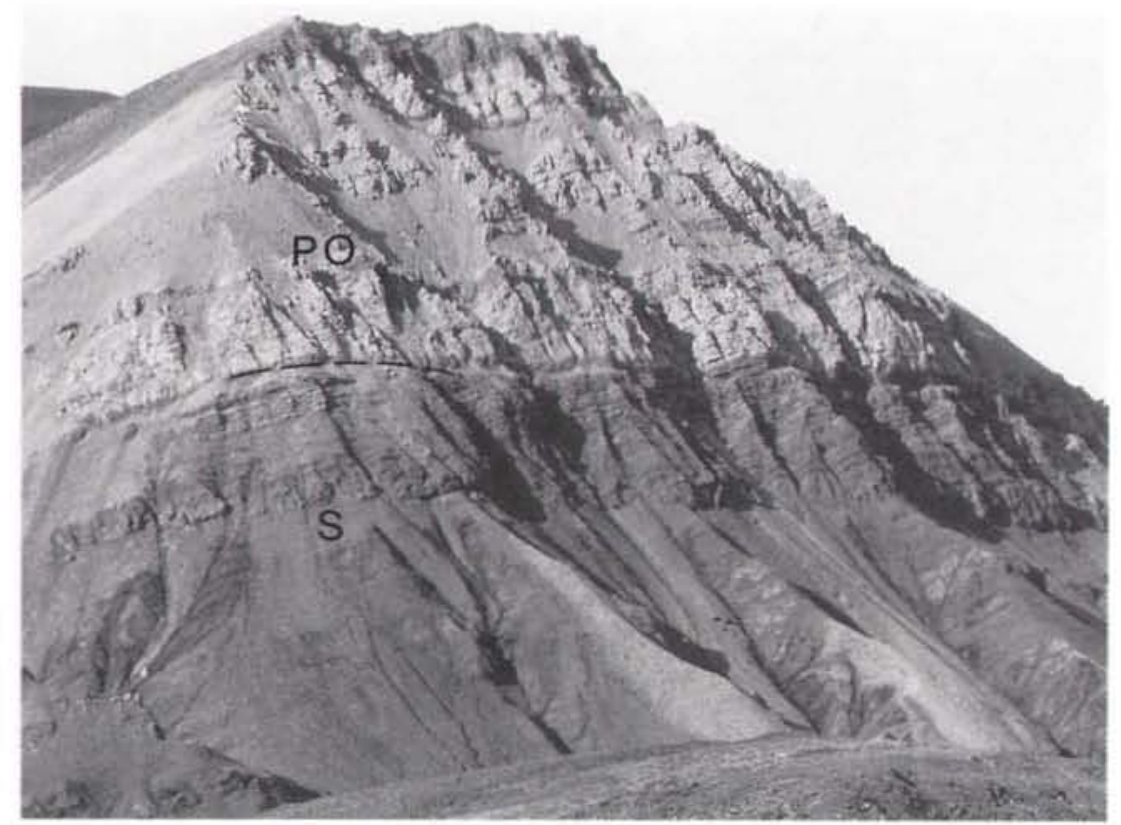




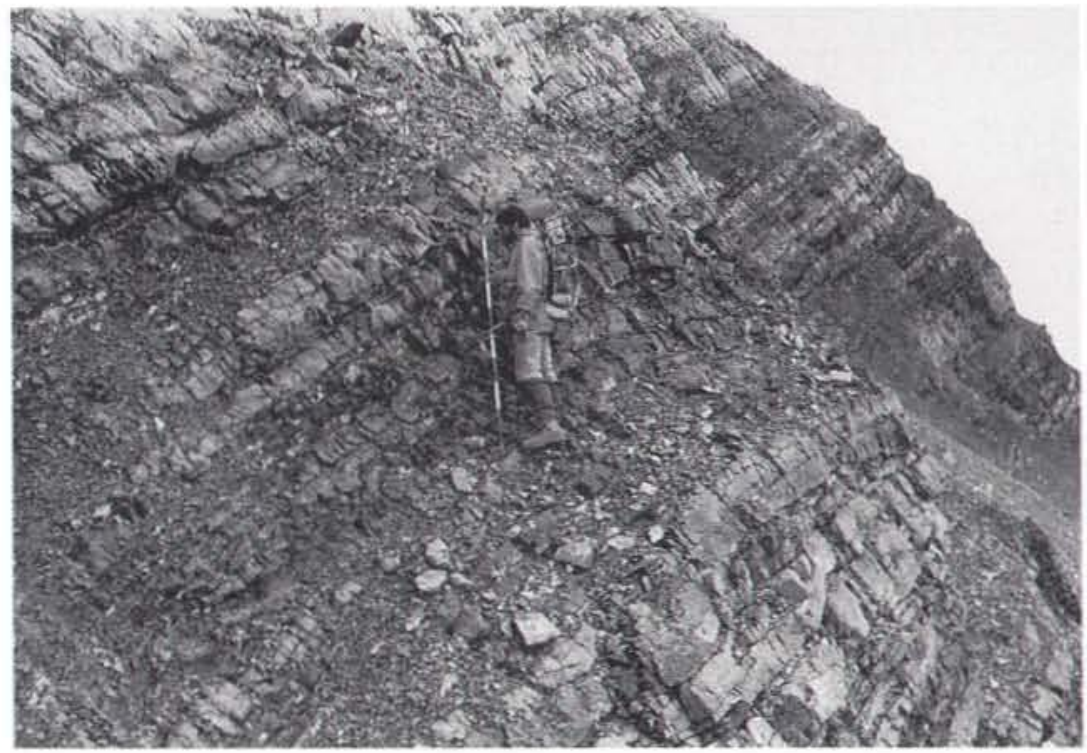

Fig. 7. Hummocky cross-stratified dolomites forming the top part of the Skagen Group (stage 1). Northern Wulff Land.

dominate in the upper $100 \mathrm{~m}$ of the group (Figs 6,7) and grade up into massive pale dolomites of the Portfjeld Formation (see stage 2 below).

The Skagen Group probably represents the earliest phase in the development of the Franklinian Basin in North Greenland. It records the initial subsidence and transgression of Proterozoic basement to produce a storm-dominated shelf that was restricted to the northernmost parts of North Greenland. The succession reflects an overall shallowing and the first differentiation of the shelf into a carbonate platform and a mainly siliciclastic storm influenced shelf leading to the development of a stable carbonate platform represented by the Portfjeld Formation (stage 2S) (Surlyk \& Ineson, 1987a).

\section{Stage 2: Early Cambrian platform and incipient trough}

The transition from the first to the second stage in basin evolution is marked by the change from mainly siliciclastic to carbonate sediments, and by a clear differentiation into shelf and deeper water trough environments (Figs 3-5, stage 2).

This stage in the evolution of the region is represented by the Portfjeld Formation on the shelf and the Paradisfjeld Group in the trough (Figs 1-4).

\section{S: Aggradational platform}

The Portfjeld Formation crops out across central North Greenland but is not known to the west of Wulff Land or to the east of Danmark Fjord. In its northern outcrop it conformably overlies the shelf sediments of the Skagen Group (Fig. 6); farther south it rests unconformably on Proterozoic strata (Figs 2, 8). The formation is poorly fossiliferous but has yielded remains of cyanobacteria of probable Early Cambrian age (Peel, 1988c).

The Portfjeld Formation is $200-280 \mathrm{~m}$ thick in southern Peary Land (O'Connor, 1979) and typically comprises cross-bedded oolitic and intraclastic dolomites, flat-pebble conglomerates, wave-rippled silty dolomites and algally laminated dolomites displaying planar, crinkly, domal, digitate and columnar stromatolites. Dark grey, bituminous, cherty dolomites form a distinctive, laterally persistent unit (10-15 m thick) near the base of the formation in this area. Oncolitic and pisolitic dolomites are present at some levels, and desiccation cracks and irregular, brecciated palaeokarst surfaces occur locally. The latter are sometimes associated with breccias containing well-rounded quartz grains in a dolomitic matrix. Together with intervals of well-rounded, medium to coarse-grained sandstones, they probably represent periods of regression and local emergence (Hurst \& Surlyk, 1983b). The association of facies suggests deposition in shallow subtidal and intertidal environments on a marine carbonate platform. Ooid and intraclast grainstones were deposited on subaqueous carbonate sand banks in shallow turbulent water while fetid and algally laminated carbonate muds and silts accumulated in protected shallow subtidal and low to moderate-energy intertidal environments.

The Portfjeld Formation thickens appreciably towards the north. In north-east Peary Land it is $400-700$ m thick (Christie \& Ineson, 1979); in the north-west 


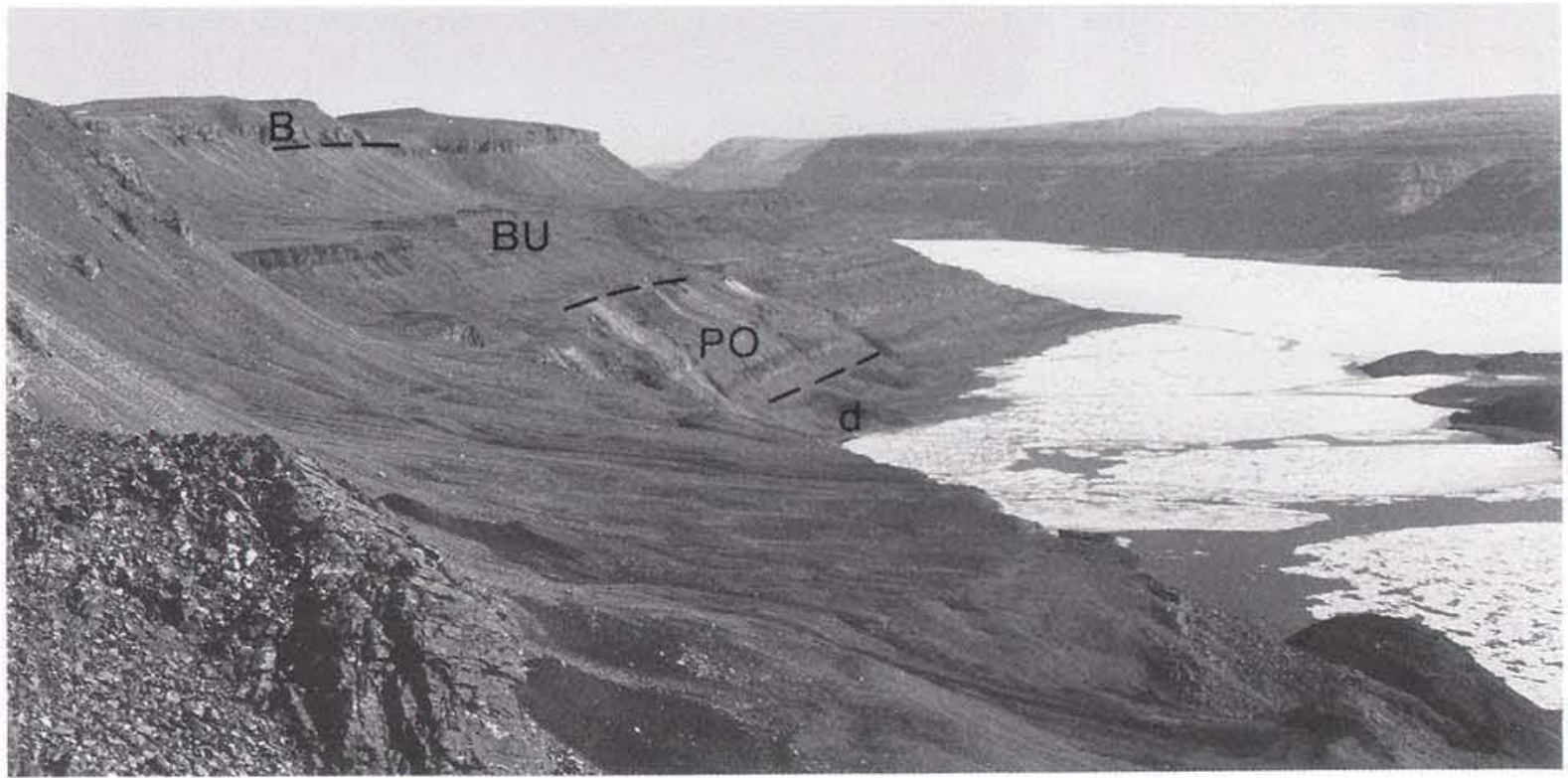

Fig. 8. Stable platform dolomites about $200 \mathrm{~m}$ thick of the Portfjeld Formation (PO, stage 2S) unconformably overlying Proterozoic red sandstones with dark weathering dolerite intrusions (d), looking eastward along Øvre Midsommersø, southern Peary Land. Succeeding siliciclastic sediments of the Buen Formation (BU, stage 3S) can be divided into a lower, inshore, sandstone unit and an upper unit of outer shelf mudstones and siltstones. The cliff is capped by carbonates of the Brønlund Fjord Group (B, stage $\left.4 S_{1 p}\right)$.

Peary Land region the formation thickens dramatically northwards over less than $20 \mathrm{~km}$ from $260 \mathrm{~m}$ at Navarana Fjord (Fig. 9) to 500-700 $\mathrm{m}$ east of J. P. Koch Fjord. In these northern exposures the formation is composed almost entirely of dolomitised ooid-intraclast grainstones, locally showing hummocky cross-stratification, with rare intervals of columnar and hemispherical stromatolites and oncolitic grainstones. This thickened succession of high energy carbonates in the north clearly represents the outer rim of the platform which accreted rapidly in response to greater subsidence adjacent to the platform/trough boundary. The thickness difference and the occurrence of mixed carbonate-siliciclastic deposits in the upper part of the underlying Skagen Group

Fig. 9. Navarana Fjord anticline on the eastern side of Navarana Fjord, exposing Skagen Group (S, stage 1) in the core, overlain by Portfjeld Formation dolomites (PO, stage 2S), dark coloured sandstones and shales of the Buen Formation (BU, stage $3 \mathrm{~S})$, and outer shelf representatives of the Aftenstjernes $\emptyset$ Formation (A), Henson Gletscher Formation (HG) of the Brønlund Fjord Group, and Tavsens Iskappe Group (T), (all stage $4 S_{1 p}$ ). The uppermost dark unit comprises dark cherts and cherty shales of a new formation of the Amundsen Land Group (AL, stage 5T) and is overlain by turbiditic sandstones of the Merqujôq Formation (ME, stage 6T). Plateau icecap is $1100 \mathrm{~m}$ high.

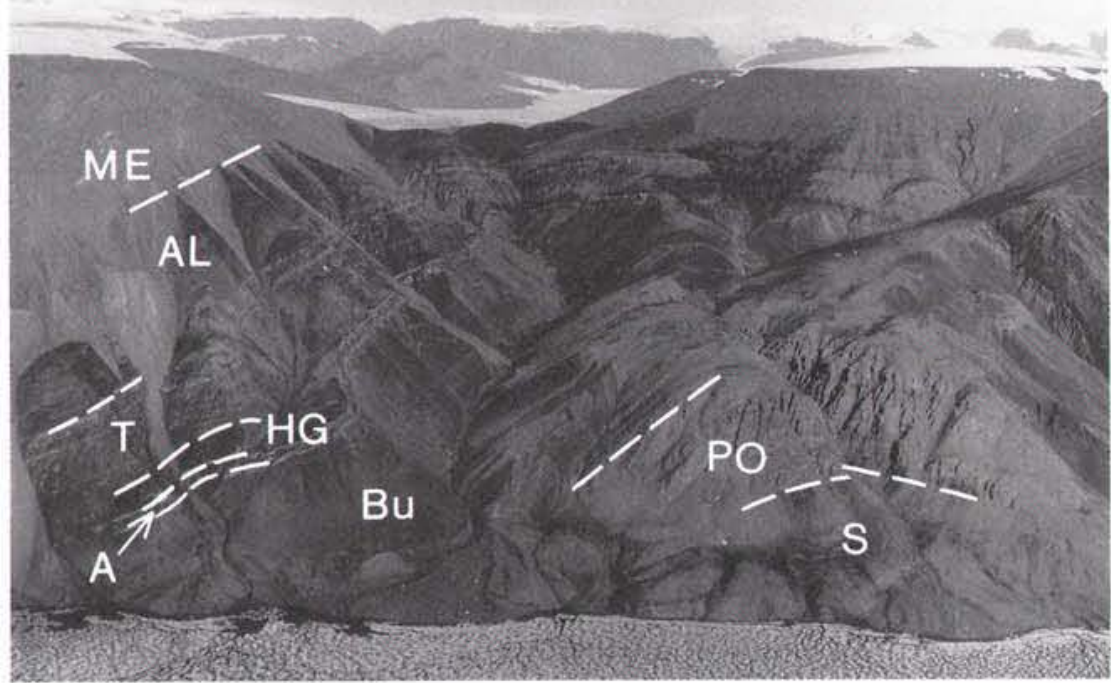


further south may suggest that deposition of Portfjeld Formation carbonates was initiated in the outer shelf while the inner shelf still received terrigenous sand and mud (Surlyk \& Ineson, 1987a). Farther north, the Portfjeld Formation is replaced by the carbonate dominated, relatively deep-water Paradisfjeld Group (see below).

The Portfjeld Formation is overlain by siliciclastic sediments of the Buen Formation without angular discordance (Fig. 8). The contact is sharp and upper levels of the Portfjeld Formation in several areas are brecciated and stained red (Davis \& Higgins, 1987); clasts of Portfjeld Formation are locally incorporated into the base of the Buen Formation (O'Connor, 1979). It is likely that this contact records subaerial exposure and the resulting demise of much of the carbonate platform; siliciclastic sedimentation was established following renewed submergence of the platform (see stage 3 , below).

The Portfjeld Formation can be readily correlated with the Ella Bay Formation of Ellesmere Island to which it shows striking similarities in both facies and evolution (Peel \& Christie, 1982; Long, 1989b). The local unconformity between the Ella Bay Formation and overlying siliciclastic sediments was interpreted by Long (1989b) as a breakup unconformity.

An important event along the southern outcrop margin of the Franklinian Basin in western North Greenland is reflected by the occurrence of a remarkable mega-breccia around the head of Victoria Fjord (Surlyk \& Ineson, 1987a). This unit varies from $85-270 \mathrm{~m}$ in thickness and was essentially formed by the collapse, break-up and mass transport of the entire Portfjeld Formation (Fig. 10). It rests upon an irregular topography of crystalline basement or thin remnants of the Upper Proterozoic Morænes $\emptyset$ Formation; it is itself overlain by undisturbed sandstones and mudstones of the Buen Formation. The breccia consists mainly of blocks and large slabs of various types of dolomite and cherty dolomite of the Portfjeld Formation, together with large clasts of quartzite, gneissic basement rocks and red siltstone, set in a carbonate matrix containing abundant, very well rounded quartz grains. Clasts are angular and very poorly sorted. The largest slabs are more than $100 \mathrm{~m}$ long and may be tens of metres thick; they are mainly subhorizontal but show all degrees of deformation, from weak bending and doming to strong folding, faulting and shearing. Slabs may have sharp boundaries or they may pass both upwards and laterally into progressively more deformed strata and eventually into disorganised matrix-supported conglomerate.

In spite of the ubiquitous occurrence of folded and tilted slabs, directional phenomena are not immediately obvious in the field. However, measurements of fold axes and the general southerly dip of slab surfaces suggest a transport direction approximately toward the north.

It is envisaged that violent earthquake activity associated with faults along the southern hinge line of the Franklinian Basin in North Greenland shattered and mobilised Proterozoic sediments and the already partly lithified and probably karstified Portfjeld Formation, generating a mega-debris flow which moved down-slope to the north. Neither the geographic location nor the geological origin of the presumed faults are known. However, a major fault zone postdating all Lower Palaeozoic strata and with downthrow generally to the south extends ENE-WSW from eastern Peary Land, crossing Henson Gletscher, the head of Jungersen Gletscher, the land area south of Nares Land and southern Wulff Land to Ryder Gletscher (see Fig. 58 in Christiansen, 1989; Map 1). This fault lies just to the north of most outcrops of the mega-breccia, but may indicate an older zone of structurally weakness possibly associated with generation of the breccia. The geometry of the mega-breccia and its relationship to undisturbed Portfjeld Formation are likewise uncertain; undisturbed Portfjeld Formation is known as far west as Nordenskiöld Fjord, with isolated outcrops in fold cores in northern Freuchen Land and northern Wulff Land. The mega-breccia extends north-eastward to the central part of the land area south of Nares Land, some $15 \mathrm{~km}$ north-east of a zone of large-scale deformation, with upright folds of high amplitude, which may represent a major ruck near the down-slope termination of the debris sheet.

\section{T: Incipient trough}

The Paradisfjeld Group (Friderichsen et al., 1982), a sequence of calcareous mudstones, dolomites and conglomerates at least $1 \mathrm{~km}$ thick, is the deep-water equivalent of the Portfjeld Formation (Surlyk et al., 1980). This group is widely exposed in Johannes V. Jensen Land and Nansen Land (Figs 1-5, Map 1), where it is strongly deformed and outcrops generally in anticlinal fold cores. Along strike from east to west there are few facies changes, whereas more marked variations occur from south to north. The group is probably entirely of Early Cambrian age, although fossils (Chancelloria and inarticulate brachiopods) are only known from the upper part (Peel \& Higgins, 1980). A two fold division can be recognised in most of the region of outcrop (Fig. 11): a thick, lower unit of dark grey, uniform, carbonate rocks, and a thinner upper unit of light coloured, more varied carbonate lithologies (Friderichsen et al., 1982). Preliminary descriptions of the group were given by 
Fig. 10. A, large bent and folded slabs of dolomite derived from the Portfjeld Formation (stage 2S). Southern Wulff Land. Note figure for scale. B, disorganised matrix supported conglomerate, which itself forms the matrix between the large slabs shown in $\mathrm{A}$.
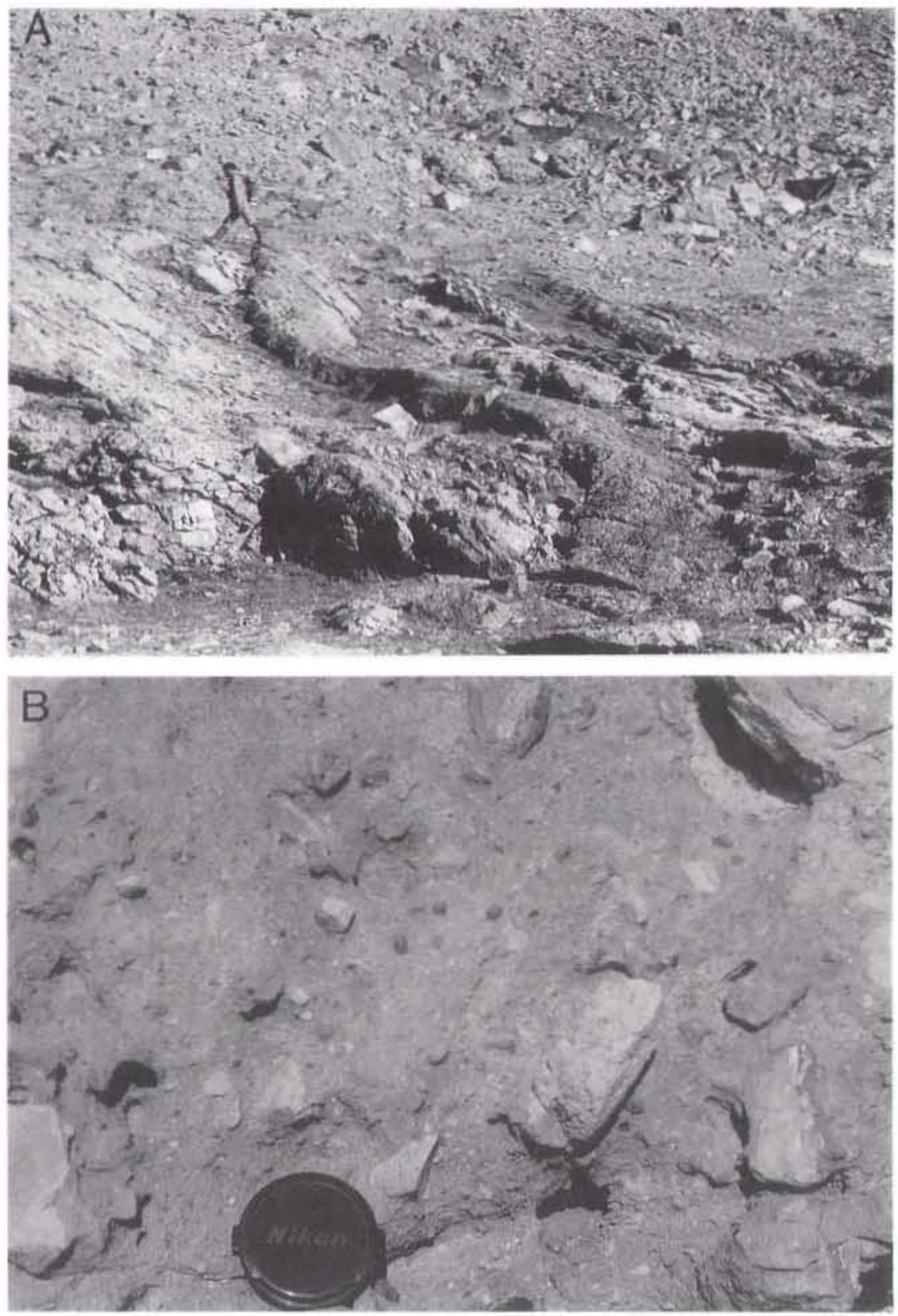

Dawes \& Soper (1973), Friderichsen \& Bengaard (1985), Higgins et al. (1981) and Soper et al. (1980).

The lower division comprises largely dark coloured, rubbly weathering carbonates and calcareous mudstones. The dark carbonates show poor bedding; textures are often deformed and recrystallised, but many seem to have been poorly sorted calcarenites. The overall uniform nature of the lower division is occasionally relieved by bands of light coloured calcareous turbidites and calcareous shales, but these are not sufficiently continuous to permit any subdivision. Limestone con- glomerates with outsize blocks (up to $50 \mathrm{~m}$ across) occur locally.

The upper unit is conspicuous on account of its yellow and orange weathering colours and varied lithologies; the generally well bedded sequence includes light grey and yellow dolomites, calcareous turbidites, a succession of up to six limestone conglomerate beds, and a transitional $20-40 \mathrm{~m}$ unit of orange-weathering calcareous shales and siltstones which passes up into the overlying Polkorridoren Group.

Calcareous shales appear and become increasingly 


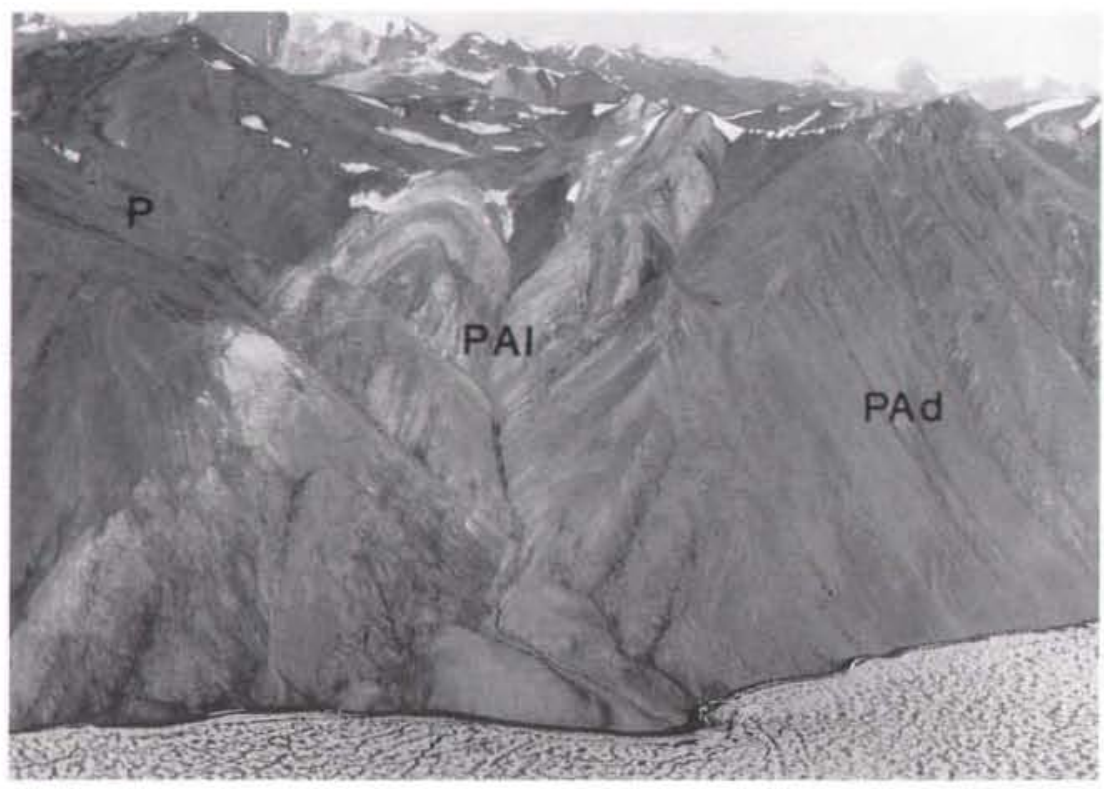

Fig. 11. Major, northerly overturned folds in eastern Nansen Land. The Paradisfjeld Group (stage 2T) is divided into a lower sequence of dark rubbly carbonates (PAd) and an upper sequence of light coloured dolomites (PAI). Overlying dark weathering rocks are siltstones and sandstones of the Polkorridoren Group (P, stage 3T). The near summits are $650 \mathrm{~m}$ above the fjord.

important in the Paradisfjeld Group towards the north, whereas the conglomerates thin out and disappear. However, details of the lithological variations are difficult to untangle in the extreme north due to the intense deformation.

Limestone conglomerates occur in the higher parts of the upper division in a broad belt over a length of 250 $\mathrm{km}$ along the southern limit of the group. Both clast supported and matrix supported types are present, the latter dominating and showing a greater variety of clast size. Clasts are mainly of light grey or pale grey carbonate, usually from a few centimetres to tens of centimetres in length, set in a fine-grained carbonate matrix; deformed rip-up clasts occur in some areas. The highest conglomerate bed characteristically has a quartz sand matrix. The beds are planar, with sharp, often erosive, boundaries, and grading is common. Bed thickness normally varies between $15 \mathrm{~cm}$ and $3 \mathrm{~m}$, but composite units as much as $15 \mathrm{~m}$ thick have been observed. The sum of the sedimentary features suggests transport by high-density turbidity currents and debris flows. The original pebble fabric commonly has a strong tectonic overprint, and transport directions have not been measured. Lithology and distribution, however, clearly indicate a source area of the conglomerates in the southern carbonate platform area.

The facies association of mainly grey limestones with calcareous turbidites and related deposits points towards a relatively deep-water slope and incipient trough environment.

The southward transition of the Paradisfjeld Group into the shallow marine sediments of the Portfjeld For- mation of the carbonate shelf has not been directly observed. The present line of demarcation between outcrops of the two units (Fig. 5, stage 2) coincides with the location of a low angle Ellesmerian thrust zone, and the transition is hidden beneath the hanging wall sequence (see Figs 65-67). A strong tectonic control of the original carbonate shelf margin, which was probably an escarpment, has been suggested, and may have coincided with a precursor to the present Harder Fjord fault zone (Surlyk et al., 1980; Surlyk \& Hurst, 1984; see Fig. 1).

Huge olistoliths derived from the Portfjeld Formation occur in the lower part of the turbiditic Polkorridoren Group (Fig. 12; Friderichsen \& Bengaard, 1985). Thus the Portfjeld Formation scarp persisted or was revived by later faulting so that parts of it were still exposed in Buen Formation - Polkorridoren Group times. Subsequent to burial beneath the Ellesmerian thrust sheets, the ancient fault line may have been reactivated in Post-Ellesmerian time to form the present Harder Fjord fault (Soper \& Higgins, 1987).

\section{Stage 3: Early Cambrian siliciclastic shelf and turbidite trough}

The passage from the second to the third stage in basin evolution is characterised by marked differential subsidence, leading to the formation of a deep-water turbidite trough. This was accompanied by the southward shift of the shelf-trough boundary to a position possibly controlled by new faults (Fig. 5, stage 3 ). The resultant shift in facies belts caused slope and trough margin deposits of the Paradisfjeld Group to be over- 


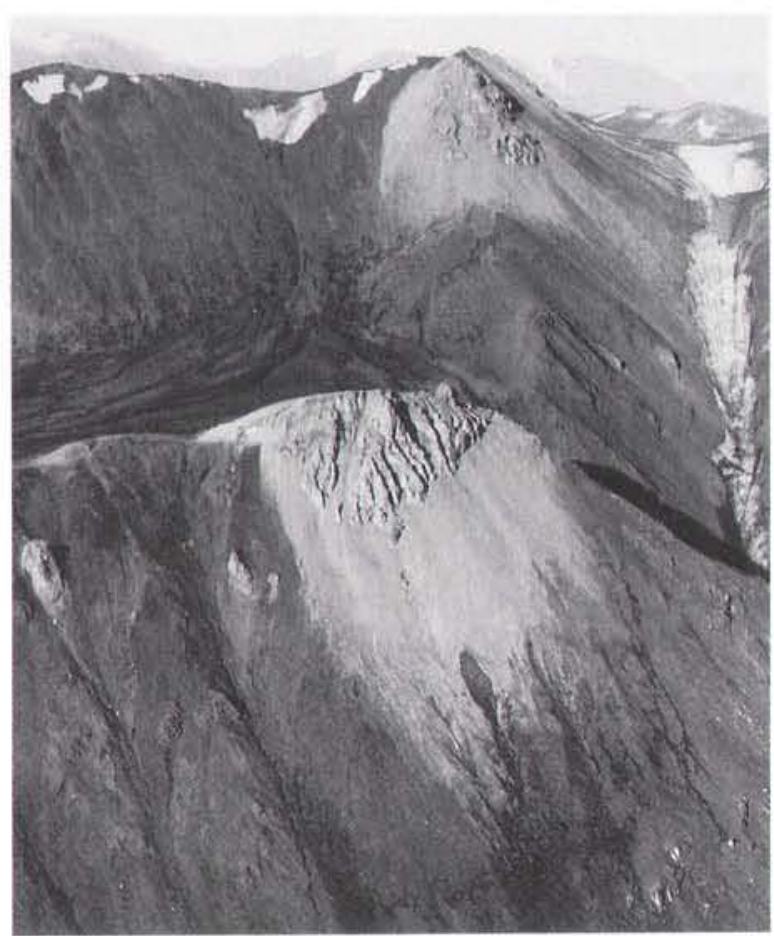

Fig. 12. Yellow weathering dolomite olistoliths of the Portfjeld Formation (stage 2S) within a siltstone sequence of the Polkorridoren Group (stage 3T), Nansen Land. The largest blocks are $150 \mathrm{~m}$ across.

lain by true deep-water trough deposits of the Polkorridoren Group, whereas the slope area retreated southwards. The marked increase in subsidence correlates with an interruption of carbonate shelf deposition. The water depth over the shelf, however, was not very great, and the area still formed a well-defined shelf contrasting with the deeper slope and trough environments. The tectonic-sedimentological setting at this stage can thus be visualised as follows:

Outside a shelf area receiving terrigenous mud and sand, a wide slope was formed, characterised by deposition in a well-oxygenated environment of red and green mudstones with occasional thin turbidites. Coarse clastic material was probably funnelled across the shelf into submarine canyons that still remain to be found. This material was deposited by turbidity currents onto several submarine fans, the outer parts of the fans showing deflection westward following the east-west axis of the basin.

\section{S: Siliciclastic shelf}

The shelf record of stage 3 is represented by siliciclastic sediments of the Buen Formation (Jepsen, 1971) in the region between Warming Land and Danmark Fjord, and the Humboldt and Dallas Bugt Formations in Washington Land and Inglefield Land, respectively (Figs 1-4; Map 1; Peel \& Christie, 1982; Peel et al., 1982). Northwards these Lower Cambrian shelf deposits grade into the turbiditic Polkorridoren Group (see below). The shelf sediments overlie the platform carbonates of stage 2 in the area east of Wulff Land (Figs 8 , 9), but are seen to overstep onto Proterozoic sedimentary rocks and Archaean gneisses to the south-west in Inglefield Land (Peel et al., 1982); their extent in the north-western part of the basin is not known as only younger rocks are exposed in these areas. Shelf sediments of stage 3 are conformably overlain by carbonates of stage 4 throughout North Greenland.

The Buen Formation (middle-late Early Cambrian) ranges between 425 and about $500 \mathrm{~m}$ in thickness in its southern outcrop, and about half this amount in the outer shelf outcrops at Navarana Fjord and in northern Wulff Land. The sediments of this stage thicken rapidly northwards into the slope and the deep-water trough (see below). They consist of a succession of sandstones and mudstones, with rare conglomerates, and typically can be subdivided into a lower, sandstone-dominated unit and an upper, recessive, mudstone-dominated unit (Fig. 8). In general, the proportion of sandstone in the formation decreases northwards; hence, the formation is sandstone-dominated in south-east Peary Land and southern Wulff Land (Jepsen, 1971; Hurst \& Peel, 1979; Bryant \& Pickerill, 1990) but consists mainly of a thick mudstone-dominated succession in the north-east Peary Land to northern Nyeboe Land area (Christie \& Ineson, 1979; Davis \& Higgins, 1987; Soper \& Higgins, 1985; Surlyk \& Ineson, 1987a). The sandstone unit contains minor conglomerate and silty mudstone interbeds. In its southern outcrop, medium to coarse-grained sandstones show abundant cross-stratification; large-scale compound sets are common and locally show siltstone drapes along low-angle foresets $\left(3^{\circ}-15^{\circ}\right)$; compound sets characteristically show a unimodal (northward) palaeocurrent pattern whereas thin to medium-bedded, glauconitic sandstones often show herring-bone cross-bedding. Bioturbation is common, particularly within thinbedded heterolithic facies from which Bryant \& Pickerill (1990; see also Bergström \& Peel, 1988) described a varied ichnofauna; Skolithos is locally abundant near the top of the sandstone unit. Hummocky cross-stratified sandstones occur at certain levels in southern outcrops but are the dominant facies in northern Wulff Land. The upper fine-grained member is composed mainly of laminated or bioturbated, grey-green silty mudstones with subordinate interbeds $(2-50 \mathrm{~cm}$ thick) of medium to fine-grained sandstone showing parallel 
and ripple cross-lamination and hummocky cross-stratification.

The Buen Formation represents a siliciclastic marine shelf environment, the sandstone unit recording inshore environments influenced by tides and high energy storms, whereas the mudstone unit reflects a low-energy, outer shelf environment in which episodic highenergy events were the result of storm-induced currents. The ubiquitous upward transition from sanddominated inner shelf to fine-grained outer shelf facies reflects a regional sea-level rise during this depositional phase.

The Dallas Bugt Formation $(25-150 \mathrm{~m})$ of Inglefield Land clearly records the marine transgression of stage 3 during a period of abundant sediment supply. Feldspathic, coarse-grained pebbly red sandstones of fluviatile origin unconformably overlie Proterozoic siliciclastic sediments and crystalline basement rocks and are succeeded by well sorted, white, large-scale cross-bedded sandstones with reactivation surfaces and massive beds with Skolithos, deposited under tidal influence. The sandstones become interbedded with bioturbated siltstones with Cruziana prior to grading up into dolomites of the overlying Cape Leiper Formation (Peel et al., 1982; Bergström \& Peel, 1988). The Dallas Bugt Formation is also recognised in immediately adjacent Ellesmere Island, where it comprises the Bache Peninsula and Sverdrup Members of Christie (1967; see Peel et al., 1982). Correlative strata in southern Washington Land are referred to the Humboldt Formation.

\section{T: Turbidite trough}

The change in trough sedimentation from the Paradisfjeld Group carbonates to the Polkorridoren Group sandstone turbidites and mudstones is a major step in the evolution of the trough and reflects a dramatic increase in subsidence, probably controlled by troughparallel faulting (Surlyk \& Hurst, 1984). The corresponding change on the shelf from the Portfjeld Formation dolomites to the Buen Formation siliciclastic sediments was initiated by shallowing of the shelf sea and exposure of much of the carbonate platform (see above). The earliest Polkorridoren Group sandstones and mudstones may correspond to a hiatus at the base of the Buen Formation (Davis \& Higgins, 1987).

The Polkorridoren Group is widely exposed in Johannes V. Jensen Land and Nansen Land, in the intensely deformed part of the North Greenland fold belt. The total thickness of the group is estimated to be 2-3 $\mathrm{km}$, and it is considered to be entirely of Early Cambrian age (Surlyk et al., 1980; Friderichsen et al., 1982). Two main facies associations are present: black, green and purple mudstones, and sandy turbidites. No formal lithostratigraphic subdivision has yet been made.

The alternation of mud-dominated and sand-dominated units, generally on a scale of $100-500 \mathrm{~m}$ thick, has proved useful in defining local, informal stratigraphies (Fig. 13). A subdivision into six or seven parts has been possible in eastern Johannes V. Jensen Land and the islands east of Nansen Land (Soper et al., 1980;

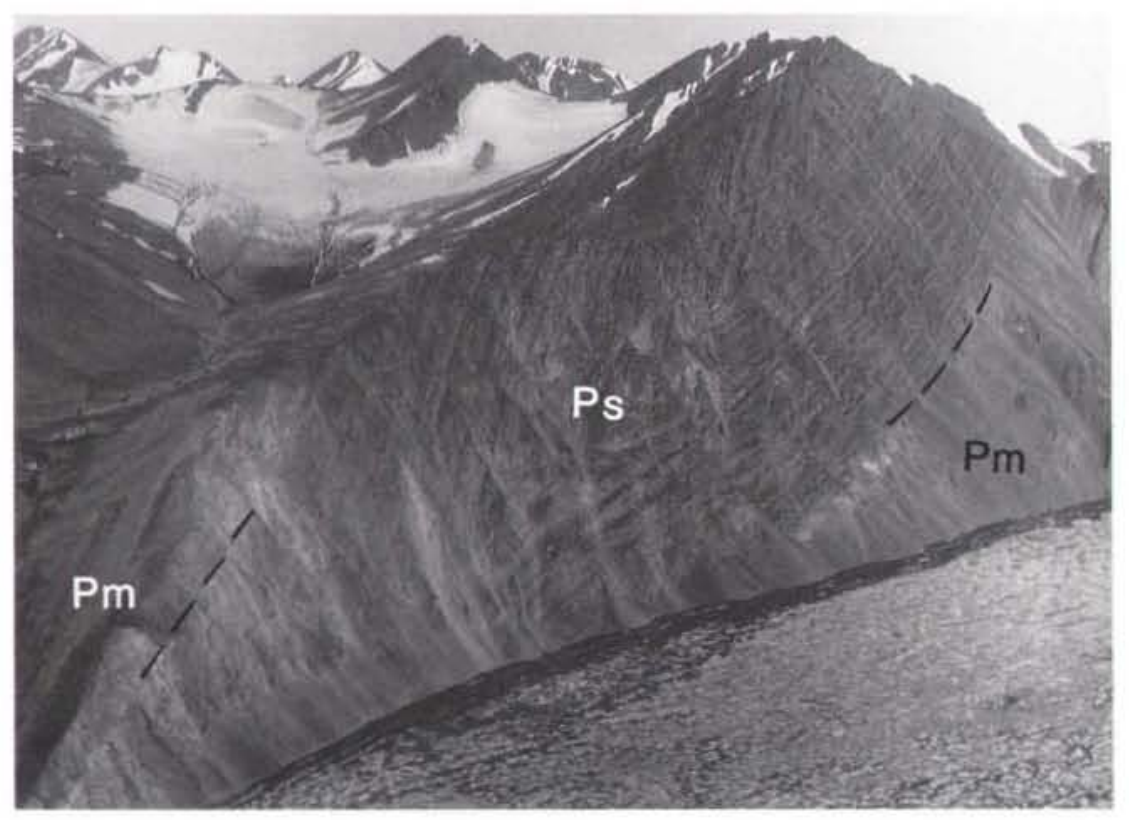

Fig. 13. Regularly bedded sandstone turbidite sequence (Ps) overlying recessive siltstone and mudstone sequence $(\mathrm{Pm})$, Polkorridoren Group (stage 3T), north-east Nansen Land. Folds are overturned northwards. Highest summits reach $1100 \mathrm{~m}$. 
Higgins et al., 1985). Correlation of these units between regions is difficult, however, and in some areas, such as western Johannes V. Jensen Land, thinly bedded, finer grained units are poorly developed and the sand-dominated sequence can be indivisible. Sand-rich units typically consist of thick, often structureless beds that are commonly amalgamated; fining-upward cycles on a scale of $50-100 \mathrm{~m}$ are recognised locally. Intervening mudstone units include thin-bedded sandstone turbidites which may show abundant trace fossils at some levels (Pickerill et al., 1982). Lateral variation in thickness can be marked, and sand-rich units locally coalesce or wedge out laterally. Carbonate conglomerate beds occur at several levels in the sequence and sometimes form persistent mapping units (see below).

The uppermost unit of the group, the Frigg Fjord mudstone (Fränkl, 1955; Dawes \& Soper, 1973; Friderichsen et al., 1982), has a more widespread, regional distribution and can be recognised in various guises between Johannes V. Jensen Land and south-east Nansen Land. Along the southern trough margin, where the sandstone turbidites have wedged out, the Frigg Fjord mudstone extends stratigraphically further downwards. This distinctive unit is up to $400 \mathrm{~m}$ thick and consists mainly of purple and green mudstones. A sequence of similarly coloured mudstones and thin, flaser-bedded siltstones and sandstones which forms the uppermost unit in north-west Nansen Land, is probably the lateral equivalent of the Frigg Fjord mudstones.

Palaeocurrent readings from Johannes V. Jensen Land show three distinct modes towards the west, north and, less commonly, east. The longitudinal transport towards the west is interpreted as representing a deflection of the outer parts of northerly directed submarine fans along the basin axis. In Nansen Land palaeocurrent readings give a dominant northward mode, with a narrow range between north-east and north-west.

A persistent and spectacular carbonate conglomerate level occurs about $600 \mathrm{~m}$ above the base of the Polkorridoren Group, and is traceable over a distance of $125 \mathrm{~km}$ throughout southern Nansen Land and the islands to the east and west (Friderichsen \& Bengaard, 1985). Individual clasts range from tens of centimetres in size to outsize blocks up to $300 \mathrm{~m}$ in diameter (Fig. 12); many blocks can be identified as Portfjeld Formation lithologies. The yellow-weathering dolomite blocks, which have been described as olistoliths, are totally enveloped by dark-weathering siltstones of the Polkorridoren Group. Relationships between the blocks and the surrounding sediments are masked, however, by the strong deformation. Most of the large blocks occur in two clusters in southern Nansen Land, spread over distances along strike of $2-3 \mathrm{~km}$ and $8 \mathrm{~km}$, respectively.
Friderichsen \& Bengaard (1985) suggested that the blocks may have been derived from a submarine canyon excavated in Portfjeld Formation dolomites at the trough/shelf transition, whereas Soper \& Higgins (1987) consider their wide east-west distribution more indicative of a line source, such as a precipitous, possibly faulted platform margin.

Strong deformation precludes detailed facies analysis and environmental reconstruction in many areas. The general picture, however, is clear. At the shelf-slope break the black and green mudstones of the upper part of the Buen Formation gradually give way to variegated, thickly developed Frigg Fjord mudstone facies characterising the wide slope area. Further north thin sandstone turbidites start to appear in the Frigg Fjord mudstones reflecting the approach of the transition of the base-of-slope area and the trough floor.

Sand was funnelled from the shelf across the slope probably through a number of canyons. These have not been observed in the field, however, most likely due to the intense deformation of the Frigg Fjord mudstones or due to cover by younger rocks. Many of the sandy turbidites were deposited in a system of relatively small borderland fans which were deflected towards the west or less commonly towards the east along the trough axis. Thick sequences of poorly-sorted, massive sandstone turbidites occur in some areas and possibly represent rapid sediment dumping in a channel mouth proximal lobe setting (Fig. 14). The dominance of sandstones in areas such as western Johannes V. Jensen Land and Nansen Land would then represent major depositional lobe systems of individual fans while intervening mudstone-dominated areas reflect interfan and basin plain environments.

\section{Stage 4: Late Early Cambrian - Middle Ordovician shelf and starved trough}

From the late Early Cambrian to the Early Ordovician, sedimentation in North Greenland was influenced by two major tectonic developments: 1 , differential subsidence and southward expansion of the east-west deep-water trough;, and 2, uplift in eastern North Greenland, probably the effect of an early Caledonian event. The influence of the latter was most pronounced in eastern North Greenland and decreased westwards (Fig. 4).

The evolution of the shelf from the late Early Cambrian to earliest Ordovician is best envisaged in terms of two components: a progradational shelf in the eastern areas (stage $4 \mathrm{~S}_{1 \mathrm{p}}$ ) influenced by uplift in south-eastern Freuchen Land, Peary Land and Kronprins Christian Land (recorded by the Brønlund Fjord and Tavsens 


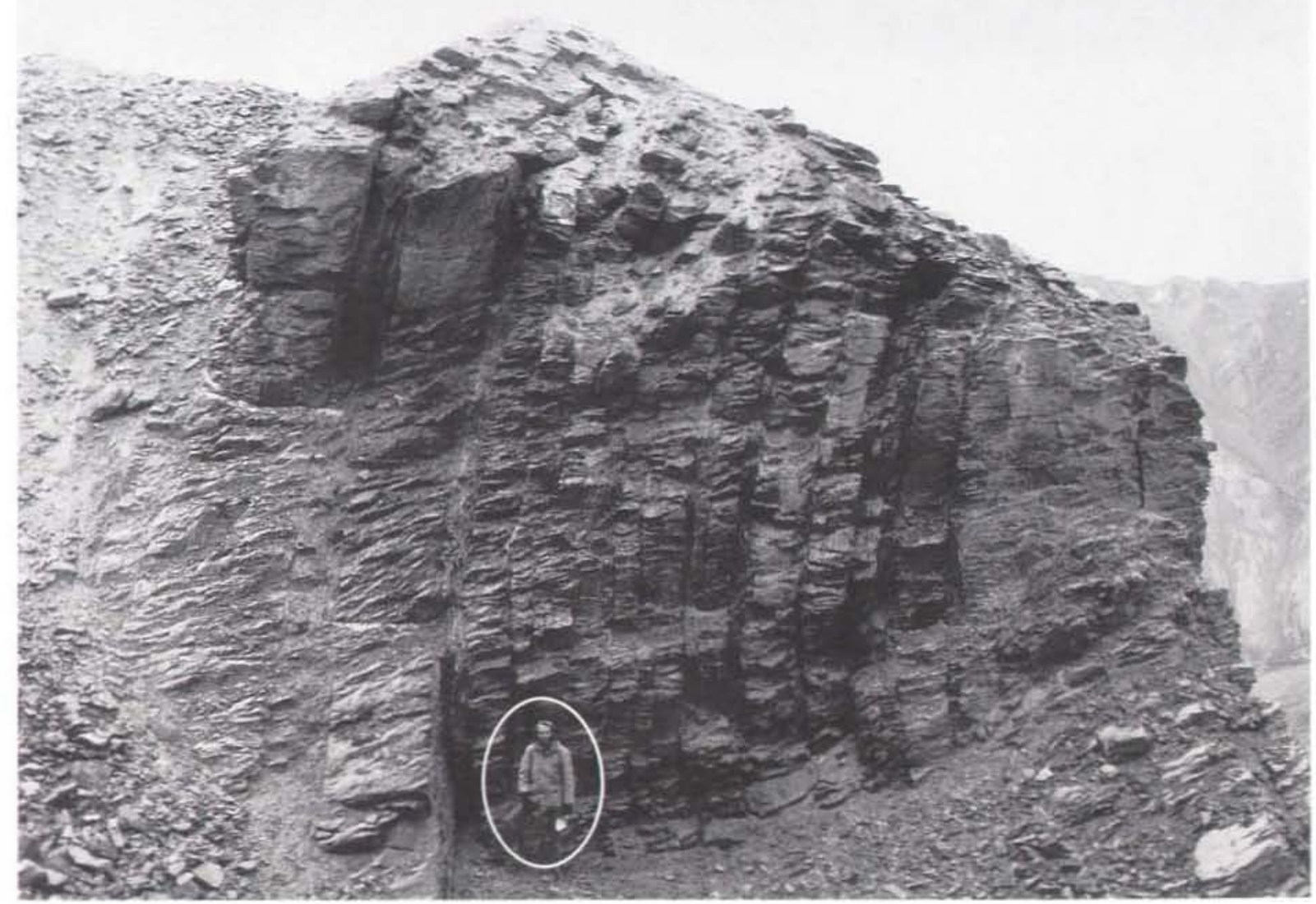

Fig. 14. Thick, poorly or non-graded mid-fan sandstone turbidites of the Polkorridoren Group (stage 3T), central Johannes V. Jensen Land. Note person for scale.

Iskappe Groups; Figs 2-4), and a western, uniformly subsiding, aggradational shelf (stage $4 \mathrm{~S}_{1 \mathrm{a}}$ ) in areas west of Nordenskiöld Fjord (represented mainly by the Ryder Gletscher Group; Figs 2-4, 15). During the Early Ordovician (stage $4 \mathrm{~S}_{2}$ ), following the end of active uplift in eastern North Greenland, the shallow-water aggradational shelf persisted in western areas and expanded in the late Early Ordovician to cover the entire North Greenland shelf (Fig. 15).

\section{S $S_{l p:}$ Progradational Cambrian shelf}

The eastern Cambrian shelf succession is dominated by the Brønlund Fjord and Tavsens Iskappe Groups which are a complex, diachronous array of prograding carbonates with subordinate siliciclastic sediments (Figs 15-17A). The Middle(?) Cambrian Koch Væg Formation is the only Cambrian representative of the Ryder Gletscher Group in this area. The Brønlund Fjord and Tavsens Iskappe Groups attain their maximum development (900 $\mathrm{m}$ in thickness) in south-west Peary Land and south-east Freuchen Land and range in age from late Early Cambrian to earliest Ordovician (Fig. 2; Ineson \& Peel, 1980, in prep.; Peel, 1982c). The succession in the type area of southern Peary Land and southeastern Freuchen Land is subdivided into twelve formations divided equally between the two groups (Fig. 16). Two additional formations of the Brønlund Fjord Group are recognised from south-west Freuchen Land to Warming Land (see stage $4 \mathrm{~S}_{\mathrm{ta}}$ ) and a further two formations are known from highly faulted outcrops in north-east Peary Land, around G. B. Schley Fjord (Fig. 16 and Map 1). The Brønlund Fjord and Tavsens Iskappe Groups also outcrop in anticlinal fold cores in the northern coastal regions from Nyeboe Land, in the west, to the J. P. Koch Fjord area, in the east (Figs 1, 9, 16). The two lowest formations of the Brønlund Fjord Group in its type area are recognised in these northern outcrops, while an overlying new formation (Kap Stanton Formation, unit 3 of Higgins \& Soper, 1985) is assigned to the Tavsens Iskappe Group (Fig. 16). $16)$.

To the east of Freuchen Land, progressive uplift and erosion resulted in an unconformity at the base of the 
WSW

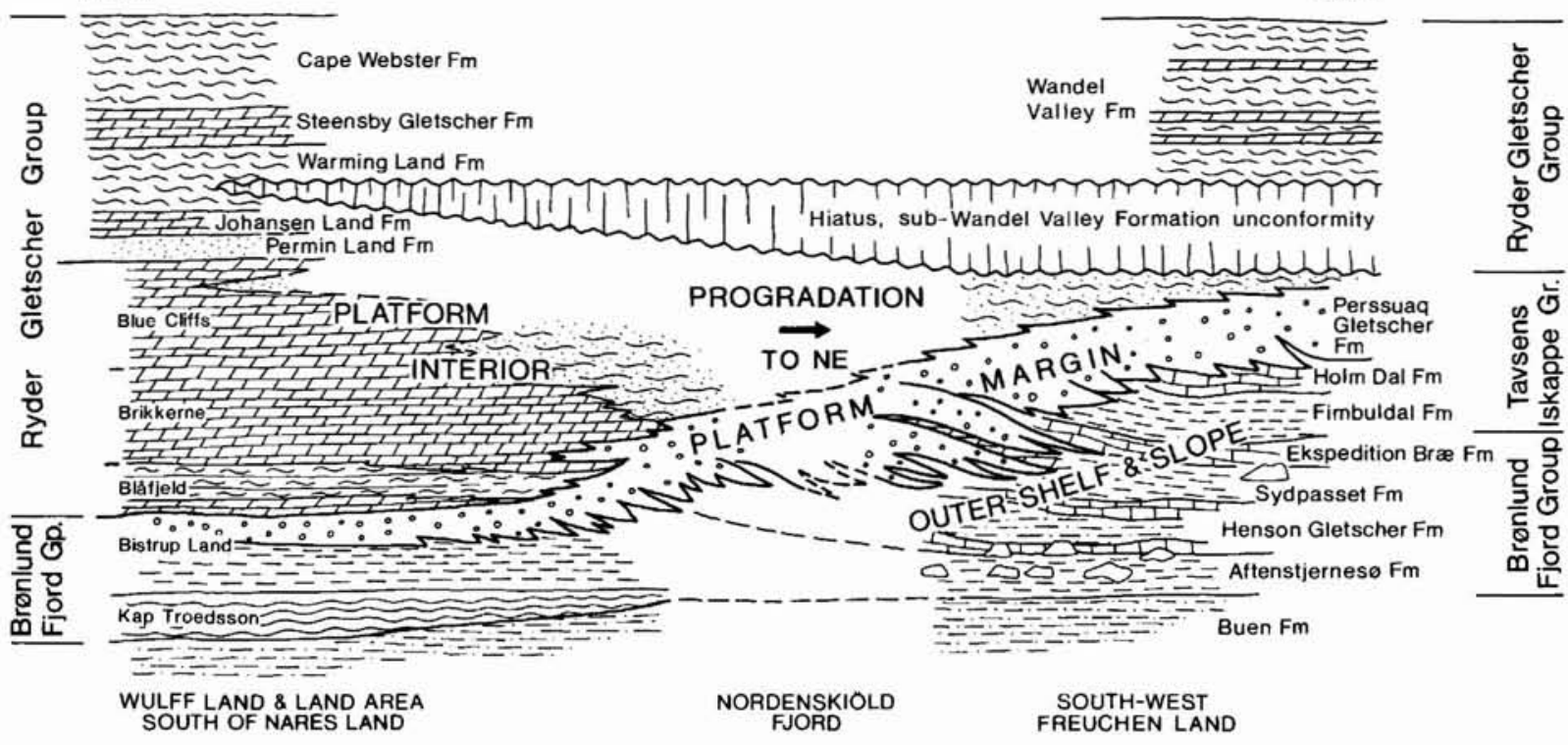

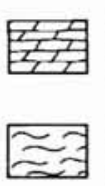

Shallow subtidal burrowed dolomites some stromatolites

Intertidal-supratidal algal laminates, flat pebble conglomerates

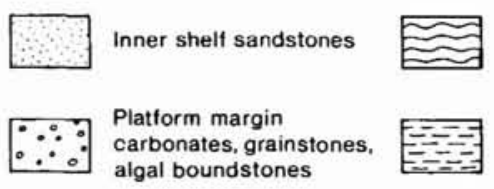

Carbonate ramp skeletal limestones and shales

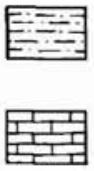

Outer shelf sandstones and mudstones

Slope carbonates mass flows, turbidites
Outer shelf carbonates. argillaceous lime mudstones

Fig. 15. Schematic cross-section showing relationships between platform interior, platform margin and outer shelf-slope rocks of stage $4 \mathrm{~S}_{1-2}$ at the head of Nordenskiöld Fjord.

succeeding Wandel Valley Formation (Early-Middle Ordovician), which consequently oversteps eastwards on to older units of the Brønlund Fjord and Tavsens Iskappe Groups to ultimately rest on Proterozoic strata in eastern North Greenland (Figs 4, 15). Thus, the Tavsens Iskappe Group has been eroded or was never deposited in areas to the east of central southern Peary Land, while the Brønlund Fjord Group persisted eastward to Independence Fjord (see Map 1).

The complex nature of the lithostratigraphic scheme applied to the sediments of the Brønlund Fjord and Tavsens Iskappe Groups (Figs 15, 16) reflects the rapid lateral facies variations within the succession (Ineson, 1985). Three major environments are recognised: starved ramp, platform margin and outer shelf-slope.

Starved ramp facies form a distinctive unit at the base of the Brønlund Fjord Group, marking the transition from the siliciclastic-dominated marine shelf (Buen Formation, stage $3 \mathrm{~S}$ ) to the succeeding carbonate regime. The remainder of the Brønlund Fjord Group and Tavsens Iskappe Group forms a progradational platform margin - outer shelf system (Fig. 15). Platform interior rocks are rarely preserved within this regressive succession and are represented only by the Koch Væg Formation of the Ryder Gletscher Group (Fig. 17A, see also Fig. 20).

The starved ramp deposits at the base of the Aftenstjernes $\emptyset$ Formation consist of a 2-7 m thick unit of phosphoritic, glauconitic skeletal grainstones, packstones and wackestones (and dolomitised equivalents) with subordinate burrowed terrigenous siltstones (Fig. 18). Bioturbation is widespread and bedding is typically nodular or wavy; sedimentary structures such as shell imbrication and current ripple cross-lamination are preserved locally. Black or dark brown phosphorite occurs as detrital grains in winnowed shell lags, as irregular nodules and within impregnated, pyritic hardground surfaces (Frykman, 1980).

This highly condensed interval clearly records a period of sediment starvation on the Cambrian shelf (Hurst \& Surlyk, 1983b; Ineson, 1985). As the supply of terrigenous sediment declined due to transgression and drowning of sediment sources, carbonate production gradually took over. The starved, muddy carbonate 


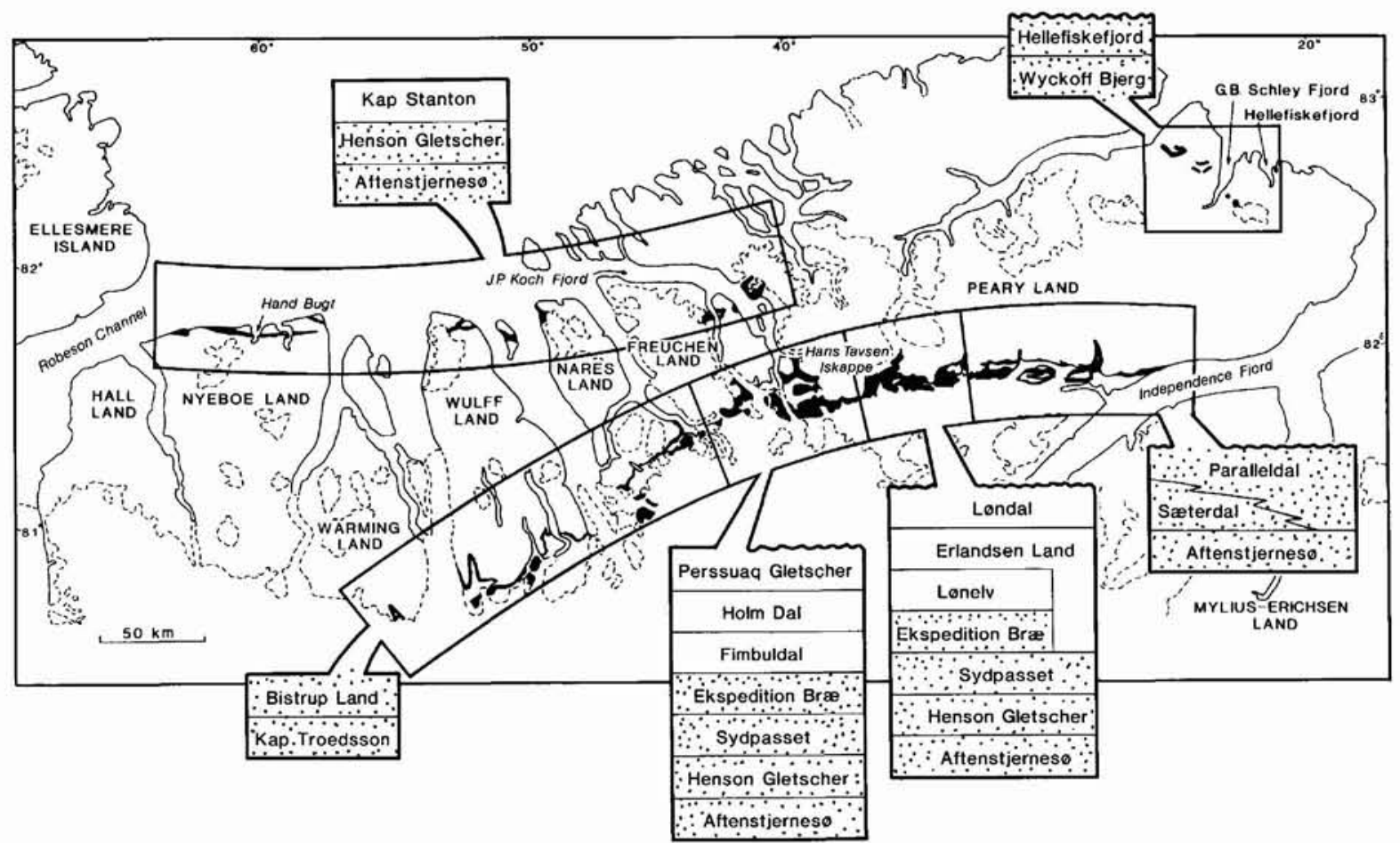

Fig. 16. Map showing the distribution (black) of the Brønlund Fjord and Tavsens Iskappe Groups in North Greenland, and their component formations (Brønlund Fjord Group stippled). These stratigraphic groups consist of platform margin and outer shelf rocks forming the Cambrian progradational succession $\left(\right.$ stage $\left.4 \mathrm{~S}_{1 \mathrm{p}}\right)$ in eastern areas and along the northern coast. West of southern Freuchen Land, outer-shelf and platform margin rocks are restricted to the Kap Troedsson and Bistrup Land Formations at the base of a thick Cambrian and Ordovician aggradational succession of platform interior carbonates (Ryder Gletscher Group, stages $4 \mathrm{~S}_{1 \mathrm{a}-2}$ ).

ramp represents the transitional phase, preceding the establishment of a flat-topped carbonate platform. This interval is equivalent to the ramp facies of the Kap Troedsson Formation in the western area (stage $4 \mathrm{~S}_{1 \mathrm{a}}$; Figs 15, 17B).

As carbonate sedimentation became established, the shelf environment was resolved into a shallow-water platform that passed northwards via a carbonate slope into a deeper water, outer shelf region. Rocks of the platform interior (Ryder Gletscher Group) pass northwards into thick bedded or massive dolomites of the carbonate platform margin (Figs 15, 17A, 19). Typically, these dolomites are trough cross-bedded, wellsorted, ooid, peloid and intraclast grainstones that record sedimentation in a high-energy, shallow-water setting at the outer margin of the platform. Associated facies in this setting include archaeocyathid-algal biostromes in the Lower Cambrian Paralleldal Formation and thrombolitic algal mounds in Upper Cambrian sandy foreslope deposits of the Perssuaq Gletscher Formation. Mature quartzitic sandstones with well rounded grains form a large proportion of the latter formation, particularly in more northerly localities, where trough cross-bedded, medium-grained sandstones alternate with bioturbated parallel-laminated sandstones and sandy mass-flow deposits (Fig. 21; Surlyk \& Ineson, 1987a).

The transition from platform edge to outer shelfslope is often marked by spectacular foreslope deposits that show northward primary dips of up to $30^{\circ}$. The foreslope grainstones and carbonate mass-flow deposits wedge out northwards, interdigitating with dark carbonates of the slope and outer shelf; this transition is superbly illustrated within the Perssuaq Gletscher, Løndal and Bistrup Land Formations, at the transition from the western aggradational platform to the eastern succession (Figs 15-17A, 20, 21).

Outer shelf and slope rocks make up over two-thirds of the Brønlund Fjord and Tavsens Iskappe Groups (Figs 15, 16, 22), forming continuous sections up to 450 $\mathrm{m}$ thick in south-western Peary Land. Typically, they consist of thinly bedded, dark, hemipelagic lime mudstones and nodular limestones, interbedded with graded limestones and chaotic carbonate breccia beds. Secondary dolomitisation affects nearly three-quarters of the succession, and occurs preferentially within thick-bed- 

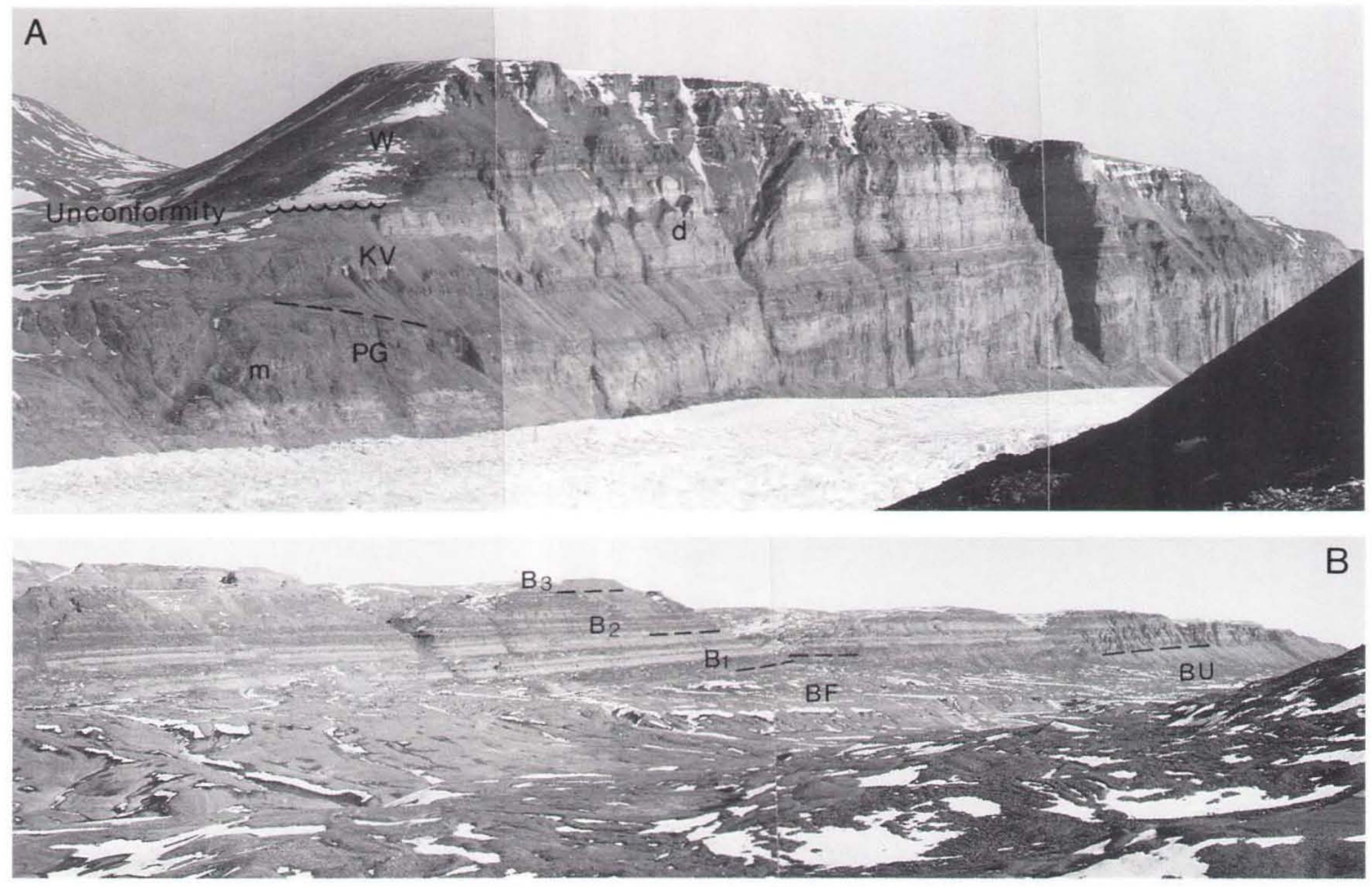

Fig. 17. A, Sequence of prograding platform margin carbonates (stage $4 \mathrm{~S}_{1 p}$ ) on the east side of Henson Gletscher, western Peary Land. Foreslope and margin sediments of the Perssuaq Gletscher Formation (PG) of the Tavsens Iskappe Group are overlain by restricted platform interior carbonates of the Koch Væg Formation (KV) and Wandel Valley Formation $(\mathrm{W})$ of the Ryder Gletscher Group (stage $4 \mathrm{~S}_{12}$ ). Northward progradation of units within the Perssuaq Gletscher Formation produced the inclined depositional surfaces seen to the right. A dolomite mound $(\mathrm{m})$ to the left is well bedded dolomites and siltstones of the Koch Væg Formation which are overlain by dolomites of the Wandel Valley Formation. The cliff is $600 \mathrm{~m}$ high, and is cut by a draped by dyke (d). B, Platform carbonates and siltstones of the Blăfjeld $\left(\mathrm{B}_{1}\right)$, Brikkerne ( $\mathrm{B}_{2}$ ) and Blue Cliffs ( $\mathrm{B}_{3}$ ) Formations of the Ryder Gletscher Group sverlying dolomites of the Brønlund Fjord Group (BF, Kap Troedsson and Bistrup Land Formations; stage $4 \mathrm{~s}_{12}$ ) and recessive siliciclastics of the Buen Formation (BU, stage $3 \mathrm{~S}$ ), south-west Wulff Land. The Bláfjeld Formation is $100 \mathrm{~m}$ thick. 


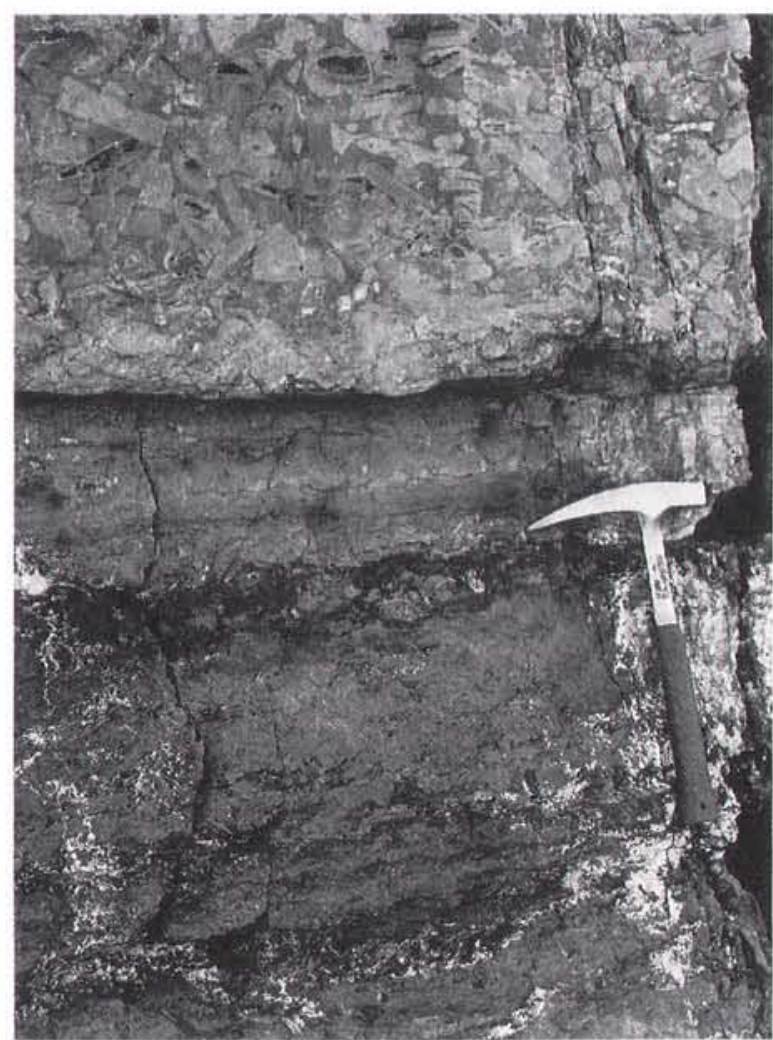

Fig. 18. Nodular glauconitic dolomites with black phosphorite nodules and hardgrounds of the starved deep ramp, overlain by mass-flow brecia representing the prograding carbonate slope. Basal Aftenstjernesø Formation (stage $4 \mathrm{~S}_{1 \mathrm{p}}$ ). Hammer for scale.

ded coarse-grained intervals. The hemipelagites are commonly bituminous, argillaceous and cherty and often contain small phosphatic brachiopods, trilobites and sponge spicules; this facies is typical of the Henson Gletscher, Ekspedition Bræ, Erlandsen Land and Holm Dal Formations (Figs 16, 22, 23). Even, parallel, occasionally micrograded, lamination is the dominant sedimentary structure. Chondrites burrows occur at certain levels. Some sections show a regular, cyclic alternation of burrowed and non-burrowed, laminated carbonate mudstones, reflecting rhythmic variations in the degree of oxygenation of bottom waters. The interbedded graded limestone beds range from silty lime mudstones less than $5 \mathrm{~cm}$ thick, to thick-bedded $(<60 \mathrm{~cm})$, coarsegrained peloidal grainstones showing Tab and Tabc Bouma divisions; they are the deposits of low-density turbidity currents derived from the upper slope and platform margin.

Very thinly bedded, nodular carbonates are a striking feature of the outer shelf and slope rocks, and are particularly well-developed in the Aftenstjernes $\varnothing$, Syd- passet and Fimbuldal Formations (Figs 15, 16). Now composed mainly of dolomite or neomorphic calcite spar, these beds show a complex, platy, nodular banding that probably reflects primary interbedding of turbiditic and hemipelagic lime mud, enhanced by early diagenetic, differential cementation. Interstratal sliding within such partially lithified sediments resulted in a spectacular array of slope creep structures. These range from pull-aparts, boudins, microfaults and discontinuous, locally discordant interstratal breccias to folds and hummocks with relief of up to $10 \mathrm{~m}$ and wavelength up to several tens of metres (Fig. 24; Ineson, 1985).

Carbonate breccia beds, often dolomitised, range from 0.2 to $45 \mathrm{~m}$ in thickness and are mainly sheet-like, non-channellised deposits. Typically clast-supported, these beds are internally unstratified, chaotic and poorly sorted, with an interstitial carbonate mud matrix; they are interpreted as the deposits of submarine debris flows (Ineson, 1980, 1985). Platform-derived blocks of ooid grainstone up to several tens of metres across are prominent in some breccia beds, particularly within the Aftenstjernesø, Sydpasset, Lønelv and Fimbuldal Formations (Figs 5, 16, 19). More commonly, however, the breccias consist of coarse pebble to cobble-sized, platy, angular fragments derived from slope environments (Fig. 25). All stages of slope mass wastage are preserved in the succession from slope creep through sliding and slumping to mass flow.

A siliciclastic sand wedge, up to $124 \mathrm{~m}$ thick, interrupts the outer shelf-slope carbonates at around the Early to Middle Cambrian boundary, forming the Sæterdal Formation and much of the Henson Gletscher Formation (Figs 15, 16). The sand wedge is persistent along depositional strike (roughly east-west) for over $300 \mathrm{~km}$, from northern Nyeboe Land to central Peary Land and, despite a general northward thinning, it extends over $40 \mathrm{~km}$ from south to north normal to depositional strike. It consists of pale-weathering, thin to very thick-bedded, fine-grained sheet sandstones, interbedded with burrowed, laminated sandy siltstones (Figs 19, 22). Although commonly structureless, some sandstone beds show dewatering structures, parallel lamination and hummocky cross-stratification. The sand was probably transported seawards during severe storms, but subsequent remobilisation and mass flow transport farther down the slope can be documented in several cases.

Coeval outermost shelf and slope rocks of late Early Cambrian to Early Ordovician age outcrop between northern Nyeboe Land and J. P. Koch Fjord in a series of anticlinal fold cores (Figs 2, 4, 16). This succession was initially described in terms of three provisional units by Higgins \& Soper (1985); their fourth unit, equivalent to the Amundsen Land Group, forms part of stage $5 \mathrm{~S}_{2}$. 


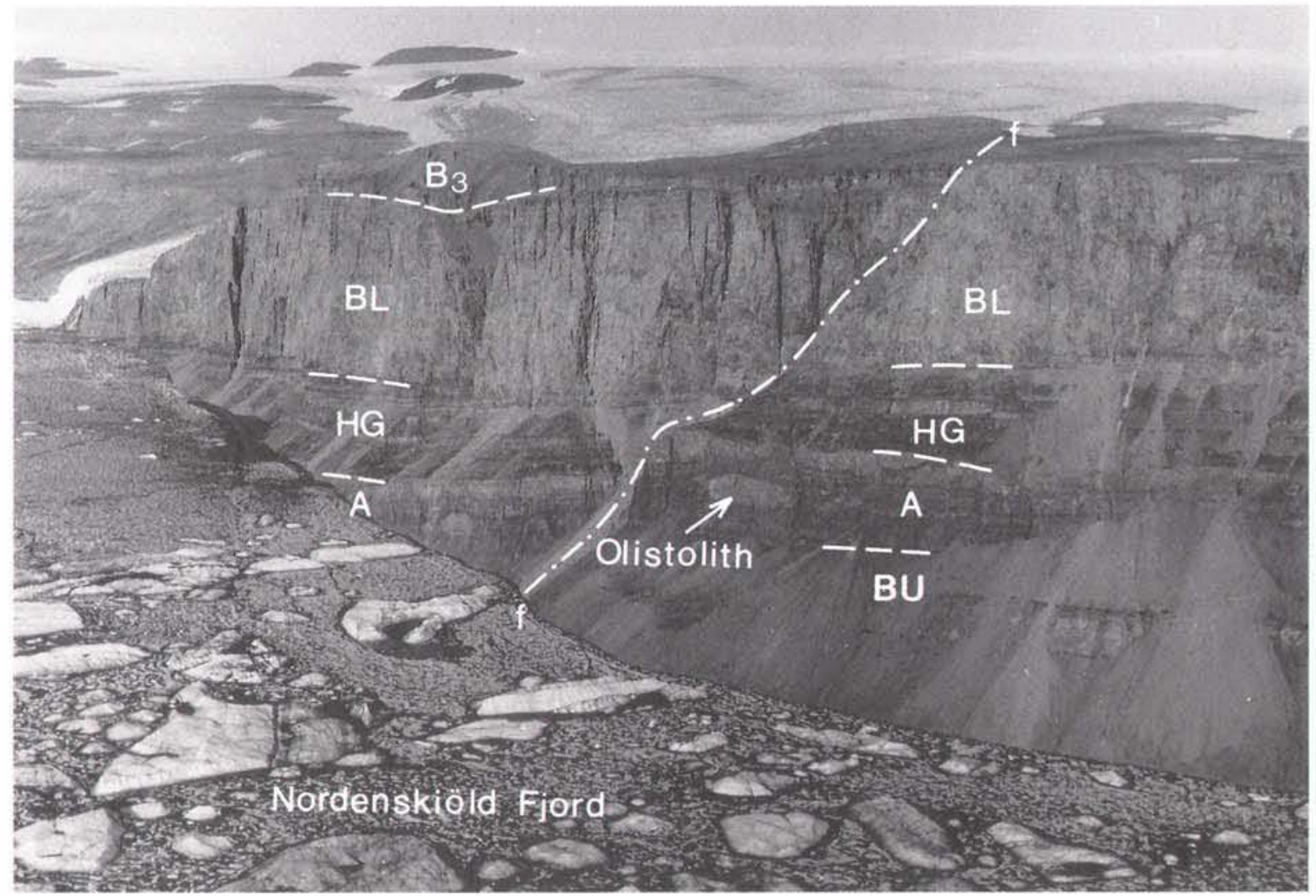

Fig. 19. Cambrian platform margin sequence at the head of Nordenskiöld Fjord. Outer shelf sandstones and mudstones of the Buen Formation (BU, stage 3S) are overlain by slope carbonates and debris flow units of the Aftenstjernesø (A) and Henson Gletscher (HG) Formations of the Brønlund Fjord Group (stage $4 \mathrm{~S}_{\mathrm{ip}}$ ) with conspicuous olistoliths. Succeeding platform margin carbonate grainstones of the Bistrup Land Formation (BL, Brønlund Fjord Group, stage $4 \mathrm{~S}_{\mathrm{la}}$ ) are overlain by platform carbonates and siliciclastic rocks of the Blue Cliffs Formation $\left(\mathrm{B}_{3}\right)$ of the Ryder Gletscher Group, stage $\left.4 \mathrm{~S}_{1 \mathrm{a}}\right)$. Cliff is $700 \mathrm{~m}$ high. $\mathrm{f}-\mathrm{f}$ : fault.

The lower two units are distal, outermost shelf representatives of the Aftenstjernes $\varnothing$ and Henson Gletscher Formations. The third unit (upper Middle Cambrian lowermost Ordovician) is considered to be a new formation of the Tavsens Iskappe Group (Kap Stanton Formation; Ineson \& Peel, in prep.), and shows a somewhat different development from its more proximal shelf equivalents (Fig. 26). It is generally between $150 \mathrm{~m}$ and $300 \mathrm{~m}$ thick, and is mainly composed of dark lime mudstones, although lime turbidites in beds from $10 \mathrm{~cm}$ to $1 \mathrm{~m}$ thick are conspicuous in eastern outcrops. Alternations of thin-bedded, grey, nodular or banded limestones and yellow-orange dolomites dominate in western outcrops, while carbonate breccia beds are common in every section.

Traced northwards towards the limit of exposure, in northern Nares Land, northern Freuchen Land and along the east side of central J. P. Koch Fjord, the division into the Aftenstjernes $\emptyset$, Henson Gletscher and Kap Stanton Formations fails and the total thickness of this succession is less than $100 \mathrm{~m}$. The deposits in these areas consist almost entirely of chert and cherty shale, indicating a starved deep shelf or slope environment throughout the late Early Cambrian to Early Ordovician. Farther north still, in southern Johannes V. Jensen Land the succession thickens again, but now represents the trough deposits of the Vølvedal Group (see stage $4 \mathrm{~T}$ ).

It is clear from Fig. 15 that the Brønlund Fjord and Tavsens Iskappe Groups together reflect a major, shallowing-upward, progradational episode, probably controlled by regional uplift of eastern North Greenland during the Middle and Late Cambrian. Fine-grained outer shelf-slope rocks dominate the succession but are everywhere overlain by, and grade southwards into, platform carbonates (Figs 15-17A, 19-22), reflecting northward progradation of shallow-water environments. In southern Peary Land, palaeocurrents, palaeoslopes and facies patterns indicate progradation towards the north-north-west, whereas in south-west 


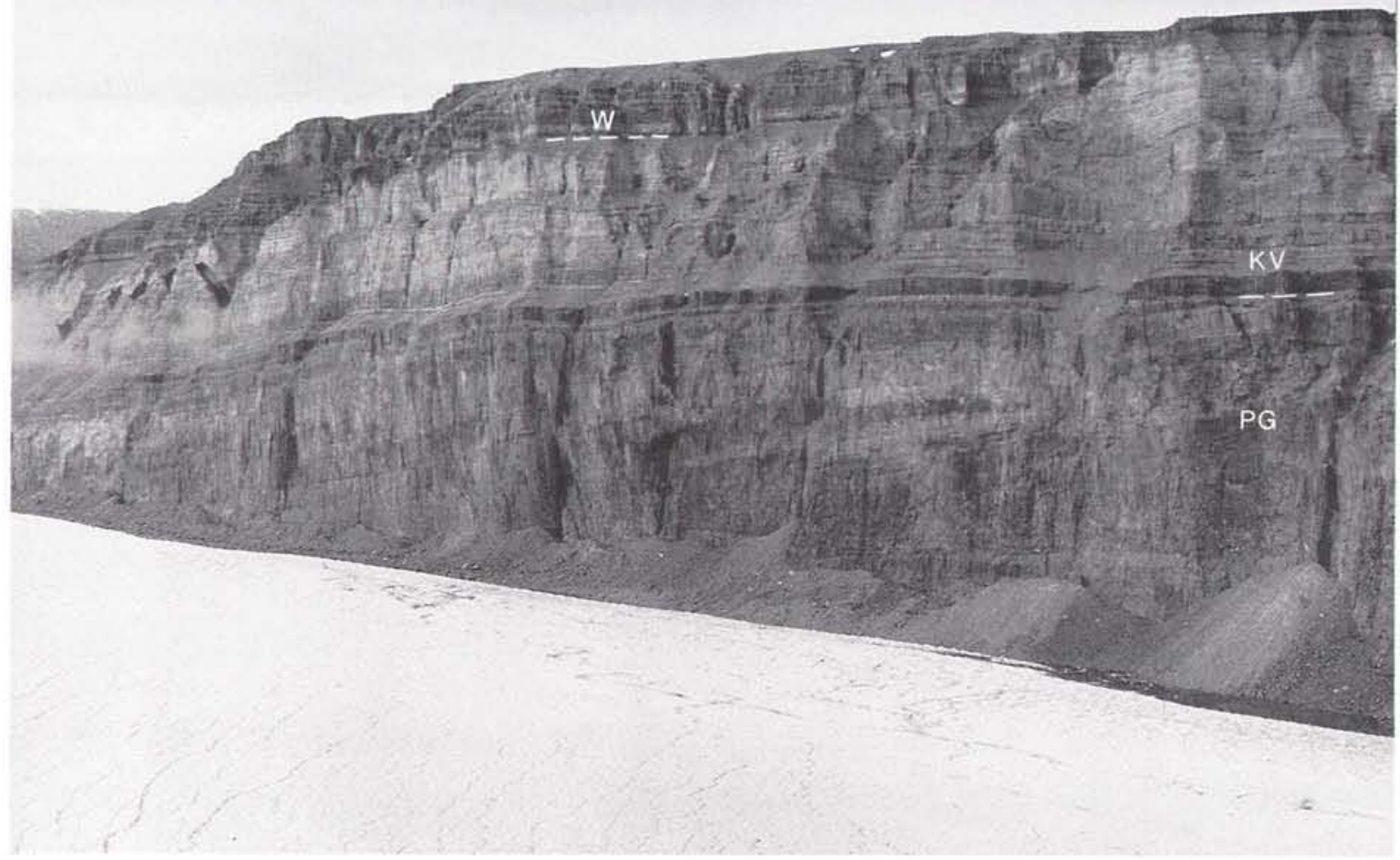

Fig. 20. Northward prograding platform margin carbonates (stage $4 \mathrm{~S}_{\text {ip }}$ ) of the Perssuaq Gletscher Formation (PG; Tavsens Iskappe Group) overlain by platform interior carbonates of the Koch Vag Formation (KV) and Wandel Valley Formation (W: note basal unconformity) of the Ryder Gletscher Group (stage $4 \mathrm{~S}_{\mathrm{la}-2}$ ). Note the lenticular, sigmoidal form of individual stratal units within the progradational interval. East side of Henson Gletscher; representing the central part of Fig. 17A.

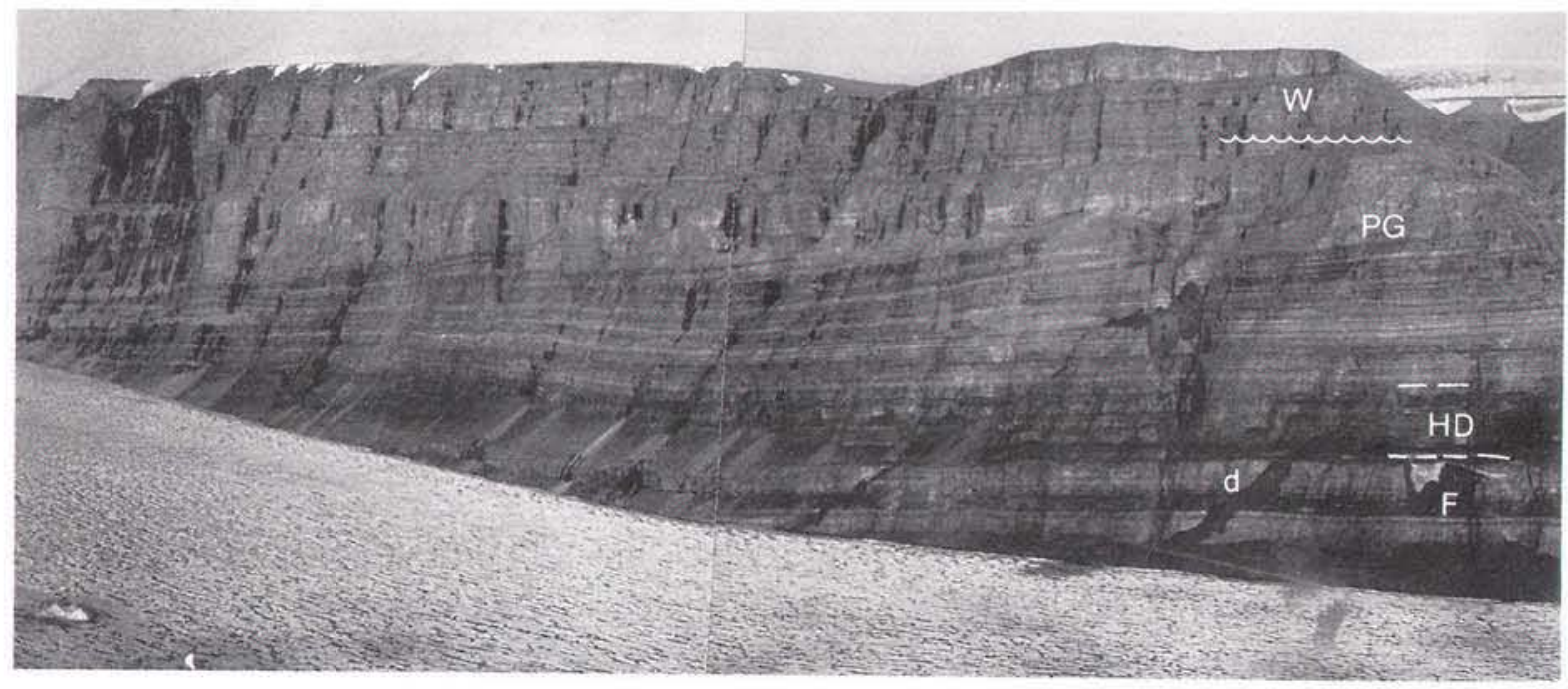

Fig. 21. Prograding siliciclastics and carbonates of the Perssuaq Gletscher Formation (PG) overlying outer shelf carbonates and shales of the Holm Dal (HD) and Fimbuldal (F) Formations (all Tavsens Iskappe Group, stage $4 \mathrm{~S}_{1 \mathrm{p}}$ ). Platform dolomites of the Wandel Valley Formation (W, stage $4 \mathrm{~S}_{2}$ ) unconformably overlie the Perssuaq Gletscher Formation. East side of J. P. Koch Fjord, western Peary Land. Height of cliff about $1000 \mathrm{~m}$; d, dyke. 


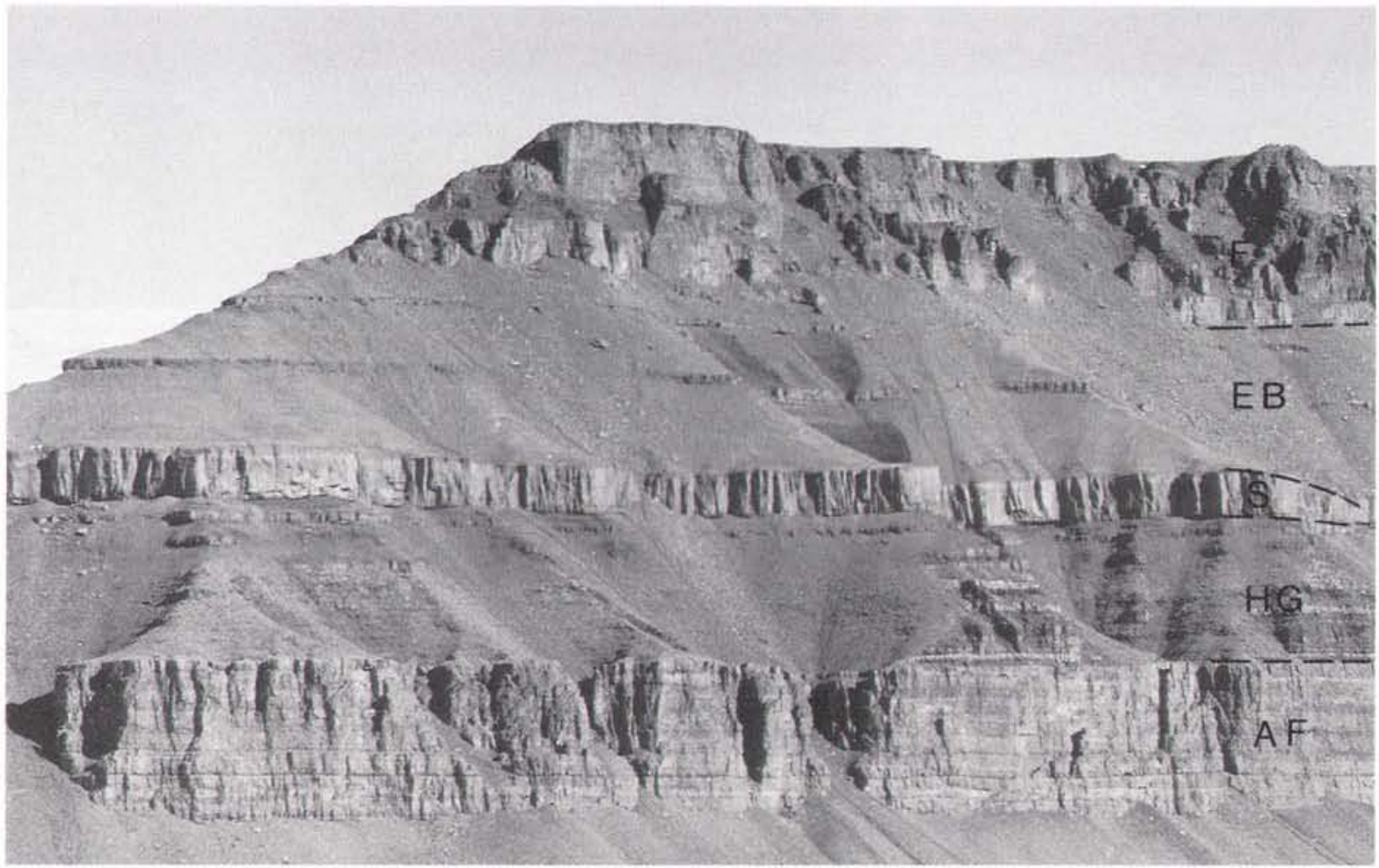

Fig. 22. Slope and outer shelf carbonate and siliciclastic sediments of the Brønlund Fjord and Tavsens Iskappe Groups (stage $4 \mathrm{~S}_{1 \mathrm{p}}$; see Fig. 16) east of J. P. Koch Fjord. Note the cyclic alternation between cliff-forming carbonate formations and recessive, mixed siliciclastic-carbonate formations; light-coloured sheet sandstones in the Henson Gletscher Formation (HG) are also visible in Fig. 19. AF, Aftenstjernesø Formation; S, Sydpasset Formation; EB, Ekspedition Bræ Formation; F, Fimbuldal Formation.

Fig. 23. Outer shelf bituminous silty dolomites of the Henson Gletscher Formation (stage $4 \mathrm{~S}_{1 \mathrm{p}}$ ) west of J. P. Koch Fjord. Note the well-developed parallel lamination and nodular structure.

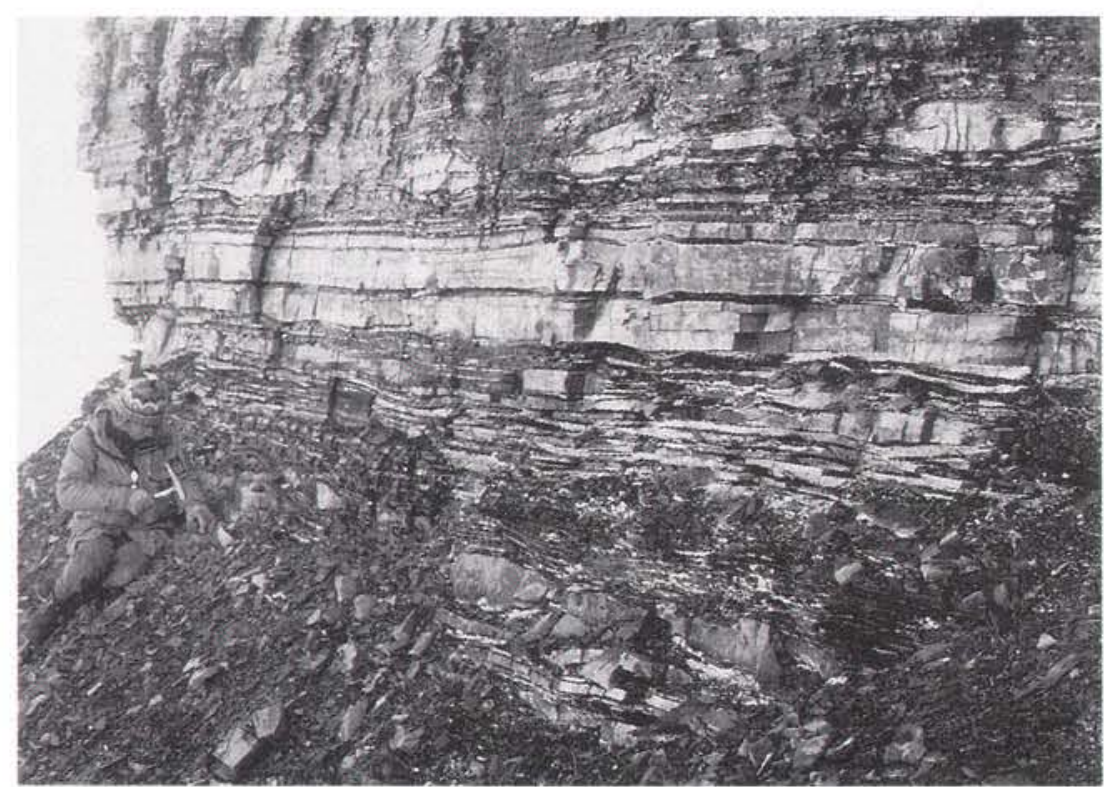




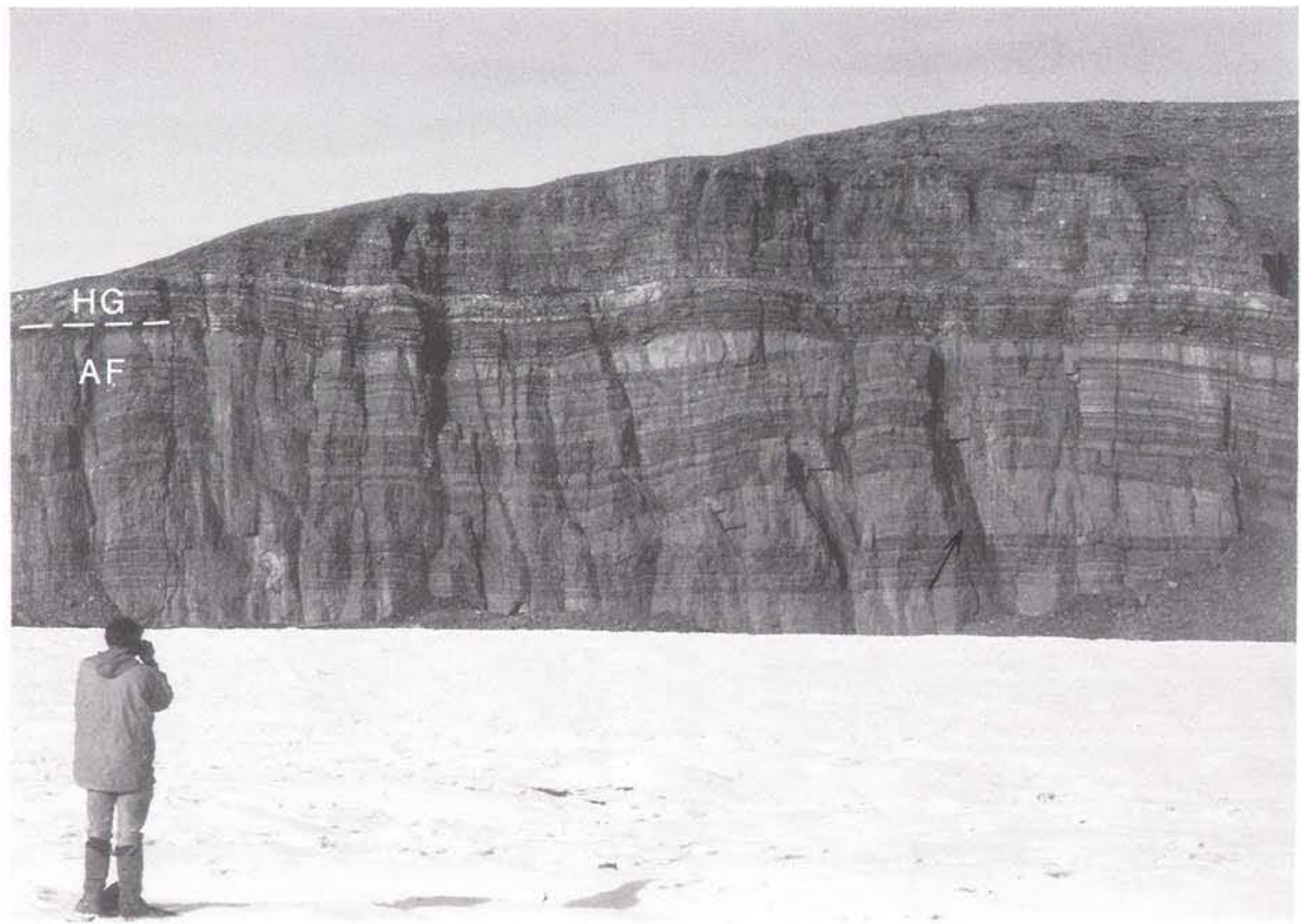

Fig. 24. Spectacular hummocks within thin-bedded slope carbonates of the Aftenstjernesø Formation (AF; Brønlund Fjord Group stage $4 \mathrm{~S}_{1 p}$ ) formed by interstratal slope creep and incipient sliding. Arrow indicates the plane of detachment. Southern Freuchen Land. HG, Henson Gletscher Formation. Height of cliff is about $100 \mathrm{~m}$.

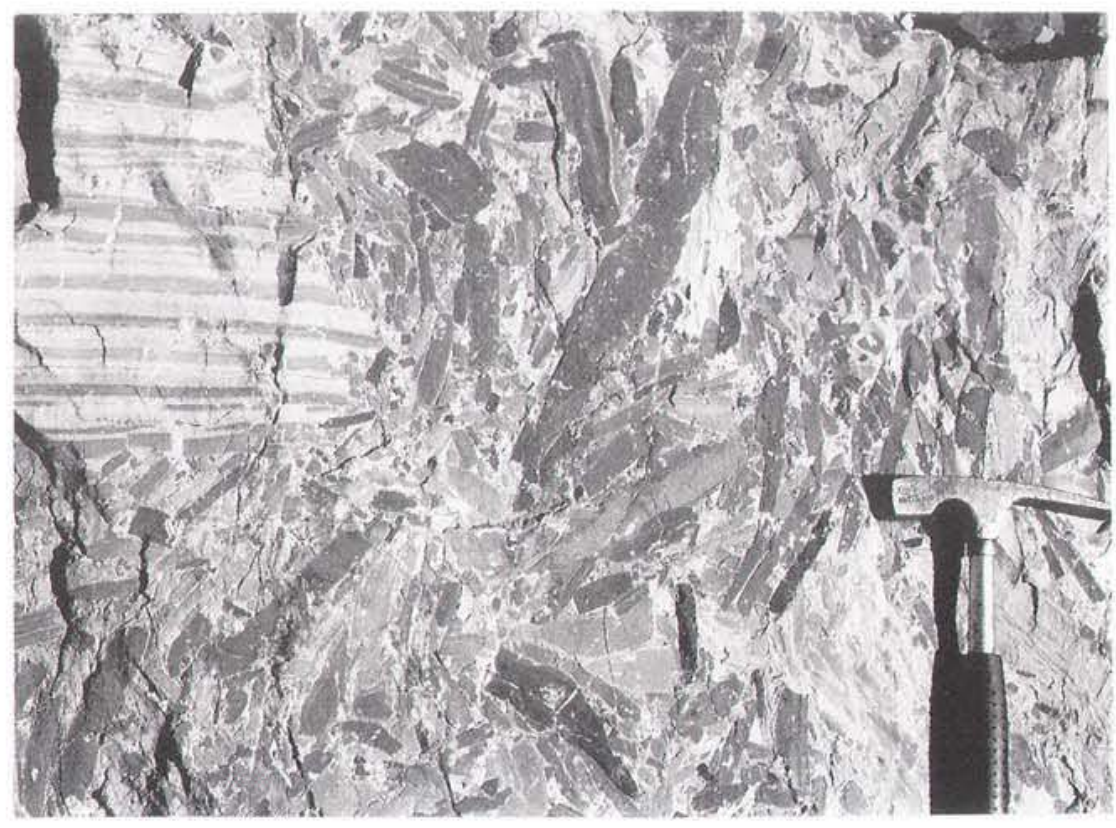

Fig. 25. Intraformational breccia (debris flow) formed of platy light and dark coloured lime mudstones; this rock type is abundant in the outer shelf equivalent of the Tavsens Iskappe Group (stage $4 \mathrm{~S}_{1 \mathrm{p}}$ ) of northern Nyeboe Land. 


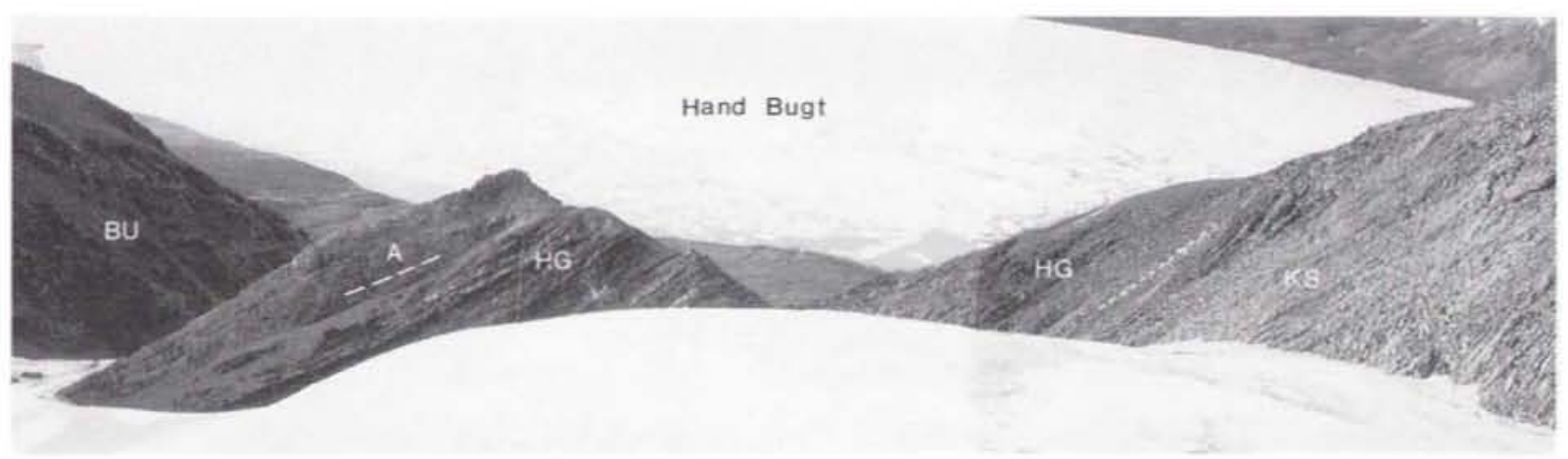

Fig. 26. Bronlund Fjord and Tavsens Iskappe Groups exposed south-west of Hand Bugt, northern Nyeboe Land; the type locality of the Kap Stanton Formation (KS). The inverted succession youngs to the right (south). BU, Buen Formation; A, Aftenstjernse Formation; HG, Henson Gletscher Formation.

Freuchen Land the platform prograded towards the north-east, at least locally. Superimposed on this overall regressive trend is a well-developed reciprocal sedimentation pattern, recording periods of extensive carbonate platform development alternating with periods of mixed carbonate-siliciclastic sedimentation (Ineson, 1988).

\section{$4 S_{I a}:$ Aggradational Cambrian platform}

The western part of the Cambrian shelf is represented by a thick and varied succession of carbonates, mainly of restricted platform aspect (sensu Wilson, 1975) with subordinate siliciclastic sediments and evaporites, which are assigned to the Brønlund Fjord Group and the lower part of the Ryder Gletscher Group (Figs 2, 15 , 17B). In the Warming Land - Nares Land area, this succession conformably overlies the fine-grained siliciclastic sediments of the Buen Formation (stage 3S). In Inglefield Land and Washington Land, to the west, the Brønlund Fjord Group is not recognised and the Ryder Gletscher Group succeeds siliciclastic sediments of stage 3S (the Dallas Bugt and Humboldt Formations; Fig. 2).

The Kap Troedsson and Bistrup Land Formations of the Brønlund Fjord Group record the evolution from the siliciclastic outer shelf (Buen Formation, stage 3S) to the shallow-water aggradational shelf (Ryder Gletscher Group) in outcrops between south-west Freuchen Land and Warming Land (Figs 15, 17B). The argillaceous lime mudstones and skeletal grainstones of the Kap Troedsson Formation (maximum thickness 65 m) represent a storm-dominated carbonate ramp that developed during the initial stages of carbonate sedimentation on the shelf. The succeeding formation (Bistrup Land Formation, $80 \mathrm{~m}$ thick) consists essentially of a lower unit of dolomitised mass-flow carbonate breccias and carbonate turbidites overlain by an upper suc- cession of trough cross-bedded and hummocky crossstratified carbonate grainstones. This formation records the progressive development and northward progradation of a flat-topped, rimmed carbonate platform with a high-energy margin and flanking carbonate slope deposits. In south-west Freuchen Land, at the transition from the western aggradational platform into the outer shelfslope succession (stage $4 \mathrm{~S}_{2}$ ), the platform margin facies thickens markedly (Figs 15, 19) and includes a $200 \mathrm{~m}$ thick sequence of dolomitised algal boundstones with archaeocyathans.

The Ryder Gletscher Group is sedimentologically best known in its type area, namely the Warming Land Nares Land region, where the Cambrian portion (Figs $2,4)$ attains a total thickness of about $470 \mathrm{~m}$ (Bryant \& Smith, 1985: Ineson \& Peel, 1987; Peel \& Wright, $1985)$. Within the eastern shelf succession the group is represented within the Cambrian only by the Middle(?) Cambrian Koch Væg Formation (Figs 17A, 20). Earlier stratigraphic nomenclature is based on sections in Inglefield Land and Washington Land where the complete Cambrian sequence of the Ryder Gletscher Group is approximately $590-680 \mathrm{~m}$ thick (summaries by Peel \& Christie, 1982; Dawes, 1976; Peel, 1982a; Fig. 2).

Cambrian strata of the Ryder Gletscher Group are in the type area assigned to the Blăfjeld, Brikkerne and Blue Cliffs Formations (Fig. 17B). They consist of dessication cracked stromatolitic and cryptalgal dolomites, dark burrow-mottled dolomites, silty lime mudstones and flat-pebble conglomerates. Thrombolitic and stromatolitic bioherms with relief of several metres are developed at several levels in this sequence (Fig. 27). Dessication-cracked, wave-rippled and cross-bedded, fine to medium-grained sandstones and siltstones occur locally in the upper half of the Blue Cliffs Formation (RG6 of Peel \& Wright, 1985). These poorly fossiliferous formations record sedimentation on a restricted 


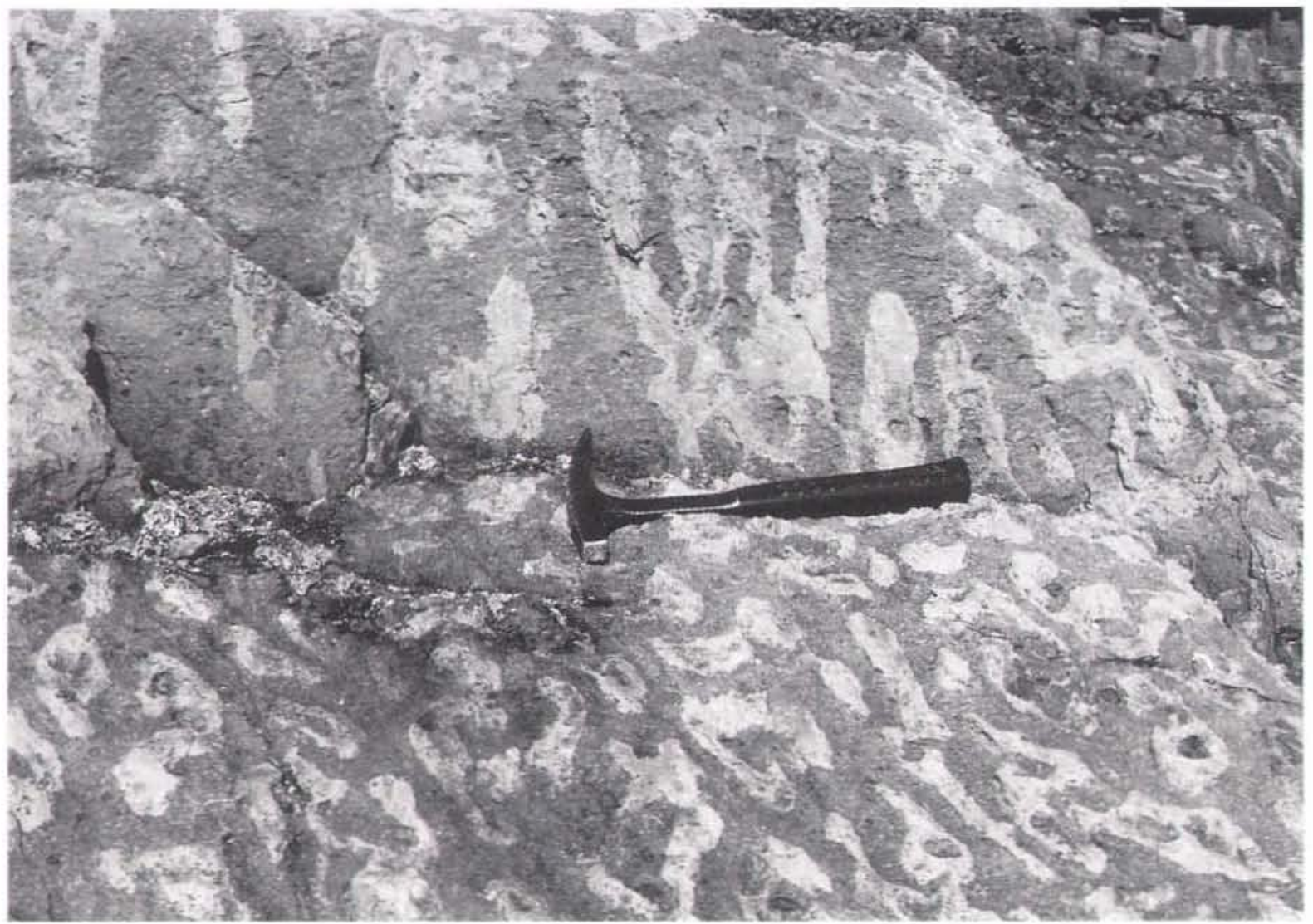

Fig. 27. Stromatolite mound within dolomites of the Brikkerne Formation (Ryder Gletscher Group: stage $4 \mathrm{~S}_{4}$ ). The horizontal and vertical sections illustrate the linked columnar form of the stromatolitic framework. South-western Wulff Land.

carbonate platform in shallow subtidal and intertidal environments. The increased siliciclastic content relative to the equivalent carbonates of the Cass Fjord Formation of Washington Land (Figs 2,4) reflects proximity to the emergent eastern shelf in Late Cambrian times (see below and stage $4 \mathrm{~S}_{1 \mathrm{p}}$ ).

Contemporaneous Cambrian platform strata of the Ryder Gletscher Group in Washington Land are assigned to the Kastrup Elv, Telt Bugt and Cass Fjord Formations (Henriksen \& Peel, 1976; see Fig. 2). The Kastrup Elv Formation (Early-Middle Cambrian) is approximately $140 \mathrm{~m}$ thick and dominated by well-bedded, mottled, crystalline dolomites (Fig. 28A). Paler units of more finely crystalline, laminated dolomites, with stromatolites, occur in the upper part of the formation. The overlying Middle Cambrian Telt Bugt Formation (5-100 m) consists mainly of thin, irregularly bedded, mottled micritic limestones with a wavy silty lamination. The formation grades up into the overlying Cass Fjord Formation which is widely distributed in Washington Land, Inglefield Land and adjacent Ellesmere Island (Peel \& Christie, 1982). The latter formation at- tains a thickness of $470 \mathrm{~m}$ in southern Washington Land, but this includes the Kap Coppinger Member $(1-30 \mathrm{~m})$ and overlying carbonates at the top of the formation, discussed below (Fig. 28B). The typical Cass Fjord lithology consists of thin, irregularly bedded, micritic limestones with a wavy, silty lamination; scours, ripple marks, dessication cracks and burrows are abundant. Laterally extensive beds of flat-pebble conglomerate up to $50 \mathrm{~cm}$ in thickness are common. Calcarenites, thinly bedded, finely recrystallised massive dolomites, thin beds of siltstone and well-sorted sandstone, rare oolites and thin beds of evaporites may be locally prominent.

The Kastrup Elv and Telt Bugt Formations resemble the Blåfjeld and Brikkerne Formations of Wulff Land and Nares Land, while the Cass Fjord Formation below the Kap Coppinger Member is very similar to the Blue Cliffs Formation. They represent environments ranging from restricted sub-tidal lagoons to intertidal and supratidal carbonate mud flats, locally evaporitic.

In Inglefield Land, large-scale cross-bedded to structureless dolomites of the Cape Leiper and Cape Ingersoll Formations (about $40 \mathrm{~m}$ ) conformably overlie 
Fig. 28. A, Carbonate sediments of the Cambrian aggradational platform succession of the Ryder Gletscher Group (stage $4 \mathrm{~S}_{\mathrm{la}}$ ) in southern Washington Land. Dolomites of the Kastrup Elv Formation (KE; Early-Middle Cambrian) are overlain by the Cass Fjord Formation (CF: Middle-Late Cambrian) of mainly micritic limestones. The intervening Telt Bugt Formation is only a few metres thick in this area, and outcrops are covered by talus. Ordovician strata forming the upper part of the Cass Fjord Formation are not visible, About $500 \mathrm{~m}$ of strata are exposed. B, Upper parts of the Cass Fjord Formation $(\mathrm{CF})$ and overlying micritic limestones of the Cape Clay Formation (CY) of the Ryder Gletscher Group (stage $4 \mathrm{~S}_{1+-2}$ ) in southern Washington Land. Quartzites of the Kap Coppinger Member (KCM: about $1.5 \mathrm{~m}$ ) approximately delimit the Cambrian-Ordovician boundary. The dark unit forming the cliff top in A forms the prominent dark unit in the middle of the cliff. Height of cliff about $500 \mathrm{~m}$.
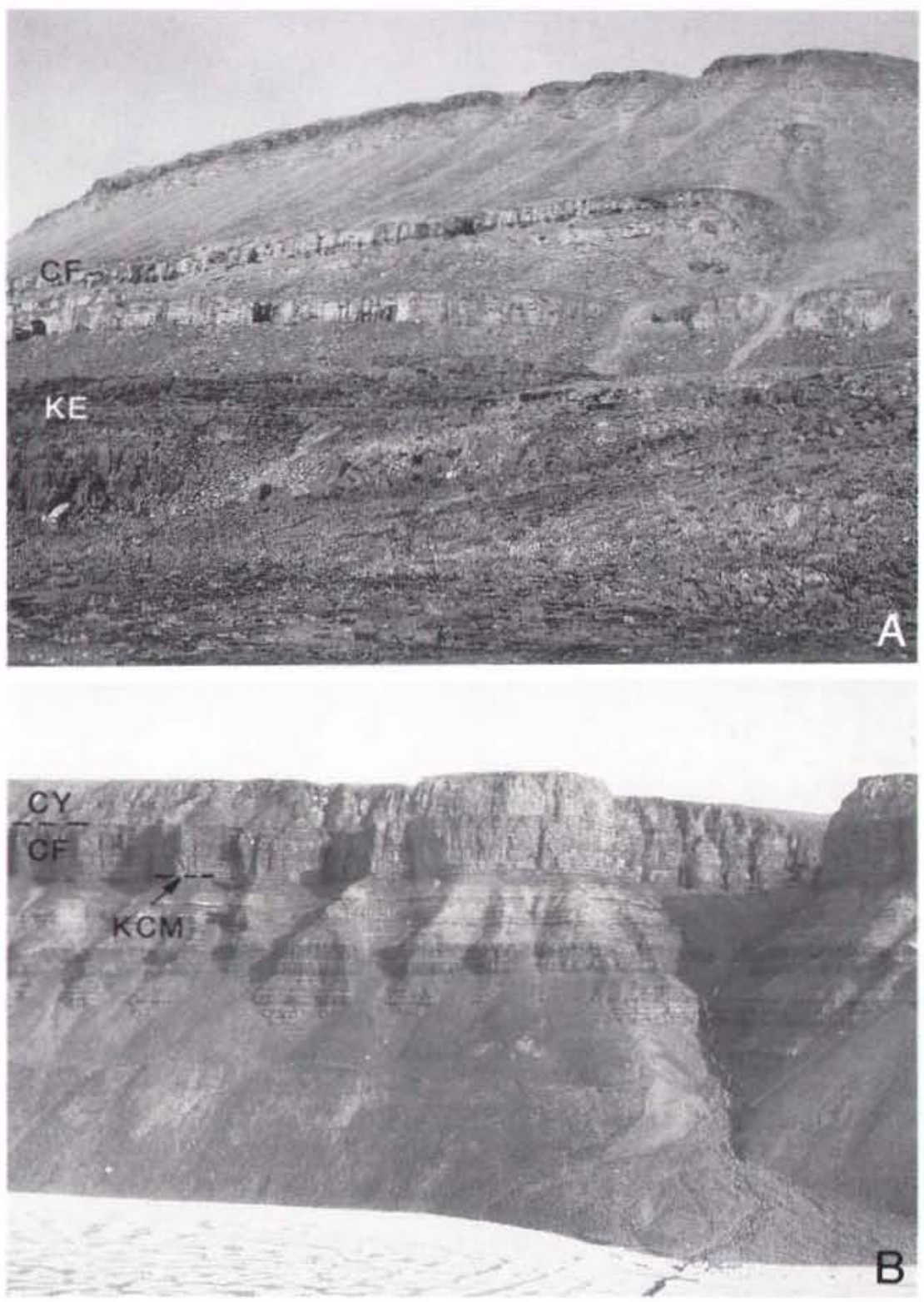

siliciclastic sediments of the Dallas Bugt Formation (stage 3S; Fig. 2). Succeeding limestones of the Wulff River and Cape Wood Formations (Lower-Middle Cambrian; thickness about $150 \mathrm{~m}$ ) are lithologically very similar to the Telt Bugt Formation of Washington Land (Peel \& Christie, 1982; Peel, 1982a). The Cape Kent Formation (Lower Cambrian; thickness 5-10 m) lies between the latter two formations in Inglefield Land. It is a distinctive unit of oolitic limestone recognised on both sides of Kane Basin (Troelsen, 1950), and represents deposition on high energy ooid sand banks in shallow turbulent water.

The Permin Land Formation and its correlative Kap
Coppinger Member of the Cass Fjord Formation form a conspicuous horizon across western North Greenland and broadly serve to separate Cambrian formations of the Ryder Gletscher Group from Ordovician formations of the same group (Figs 28B, 29). The Permin Land Formation conformably overlies the Blue Cliffs Formation between Warming Land and the land area south of Nares Land (Fig. 29) and is of earliest Ordovician age (Bryant \& Smith, 1985, 1990). It comprises up to $53 \mathrm{~m}$ of well-sorted, well-rounded medium to fine-grained sandstones with subordinate grey dolomite and siltstone interbeds. Sedimentary structures include trough and tabular cross-bedding, wave-ripple lamina- 


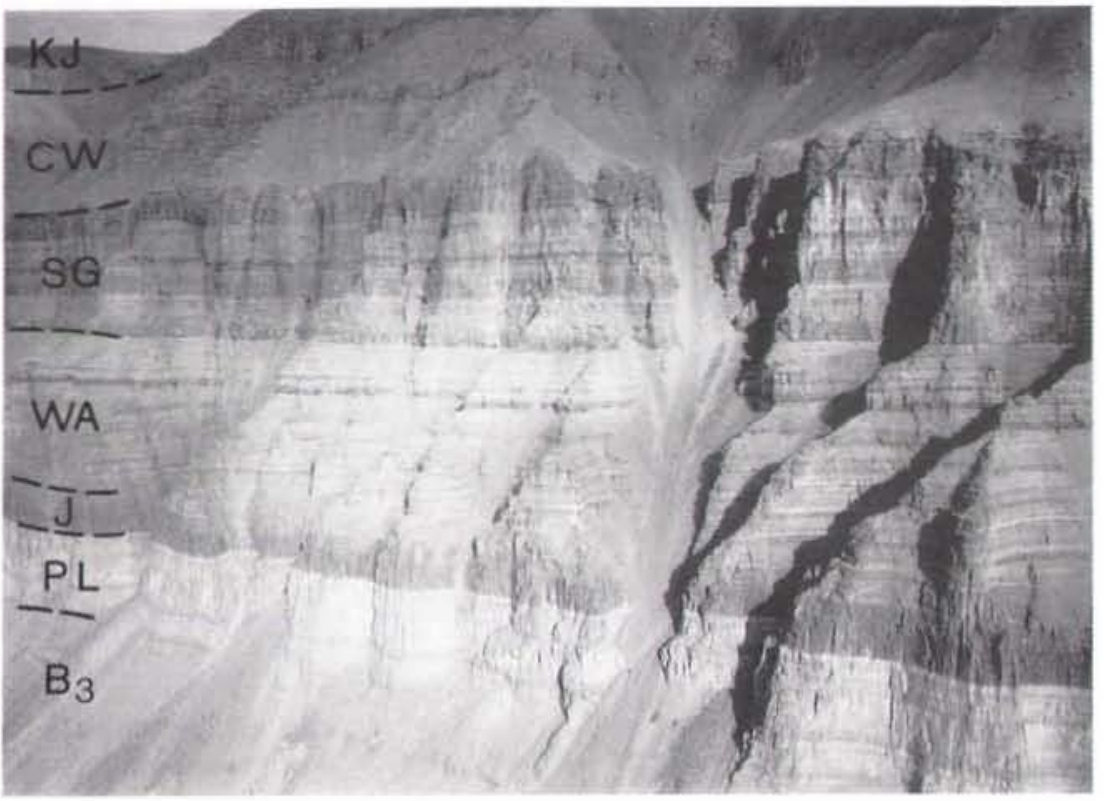

Fig. 29. Section from the upper part of the Blue Cliffs Formation ( $B_{3}$ ), at base, through the Permin Land $(\mathrm{PL})$, Johansen Land $(\mathrm{J})$, Warming Land (WA), Steensby Gletscher (SG) and Cape Webster (CW) Formations, all Ryder Gletscher Group (stage $4 \mathrm{~S}_{1,-2}$ ) of platform interior origin. The Kap Jackson Formation (KJ) of the Morris Bugt Group (stage $5 \mathrm{~S}_{1}$ ) forms the top of cliff. which is $600 \mathrm{~m}$ high. Southern Permin Land.

tion and flat and low-angle lamination; palaeocurrent directions are widely dispersed (Bryant \& Smith, 1985. 1990). The formation represents a shallow marine sand sheet of considerable lateral extent which can be traced westwards from south-western Freuchen Land into Washington Land where it forms the Kap Coppinger Member of the Cass Fjord Formation (Figs 2, 28B). This widespread clastic incursion during the earliest Ordovician is correlated with the time of maximum regression and exposure in eastern North Greenland (Fig. 4). Furthermore, Bryant \& Smith (1990) propose that pulses of westward progradation of siliciclastic sediments can be correlated with eustatic sea-level lowstands. Broadly contemporaneous siliciclastic incursions also occurred in outer shelf environments (upper Tavsens Iskappe Group) and in trough environments (Vølvedal Group).

Outer shelf and slope facies of Cambrian and early Ordovician age in this western area are exposed intermittently along the northern coastline of western and central North Greenland between Nyeboe Land and Nares Land. These rocks are readily correlated with the more extensive outer shelf-slope rocks of the progradational eastern shelf and have been described briefly together with the eastern succession (see stage $4 S_{1 p}$, above).

\section{S:- Ordovician aggradational platform}

Regional uplift of the eastern shelf was probably initiated as early as the late Early Cambrian (uppermost stage 3 ) and culminated in extensive exposure of the shelf during the latest Cambrian and earliest Ordovician. The resultant hiatus decreases in stratigraphic importance towards the west (Figs 2, 4, 15, 30, 31). Although the hiatus partly represents non-deposition due to progressive shelf exposure during the later part of the Cambrian, it also records extensive erosion of earlier Cambrian and late Precambrian strata. In eastern North Greenland, this erosion may have removed up to I km of section and the detritus was probably shed northwards, contributing to the North Greenland trough fill in the latest Cambrian and Early Ordovician (Hurst \& Surlyk, 1983b; Surlyk \& Hurst, 1984). In south-western Peary Land and Freuchen Land, shelf emergence was preceded by deposition of a thick succession of northward-prograding quartz-rich siliciclastic sediments (Perssuaq Gletscher Formation; Fig. 21) of Late Cambrian to earliest Ordovician age. This regressive clastic influx is represented farther west by the shallow marine siliciclastic sediments of the Permin Land Formation (see stage $4 \mathrm{~S}_{1 \mathrm{a}}$ and Fig. 15; Bryant \& Smith, 1990) and to the north in the trough by the sandstone turbidites of the Vølvedal Group (Surlyk \& Hurst, 1984; Surlyk et al., in prep.). Migration of these regressive siliciclastic sediments over the exposed karstified platform in the east is recorded by sandstone infilling karstic fractures and vugs.

This episode of westward propagating, progressive regional uplift in eastern areas of North Greenland during the later part of the Cambrian and earliest Ordovician has been interpreted as the record of westward expansion of a peripheral bulge during an early collision event along the western margin of the Iapetus Ocean 
Fig. 30. Lower Ordovician dolomites of the Wandel Valley Formation (W: Ryder Gletscher Group, stage 4S ) unconformably overlying Lower Cambrian dolomites of the Brønlund Fjord Group (BFG; Aftenstjerness and Paralleldal Formations; stage $4 S_{1 p}$ ). The hiatus represented by the unconformity beneath the Wandel Valley Formation decreases in magnitude to the west such that angular discordance has not been recognised west of Nares Land (see Fig. 31). Southern Peary Land, with the base camp used during the first phase of the North Greenland Project. Bu, Buen Formation. Cliff is $600 \mathrm{~m}$.

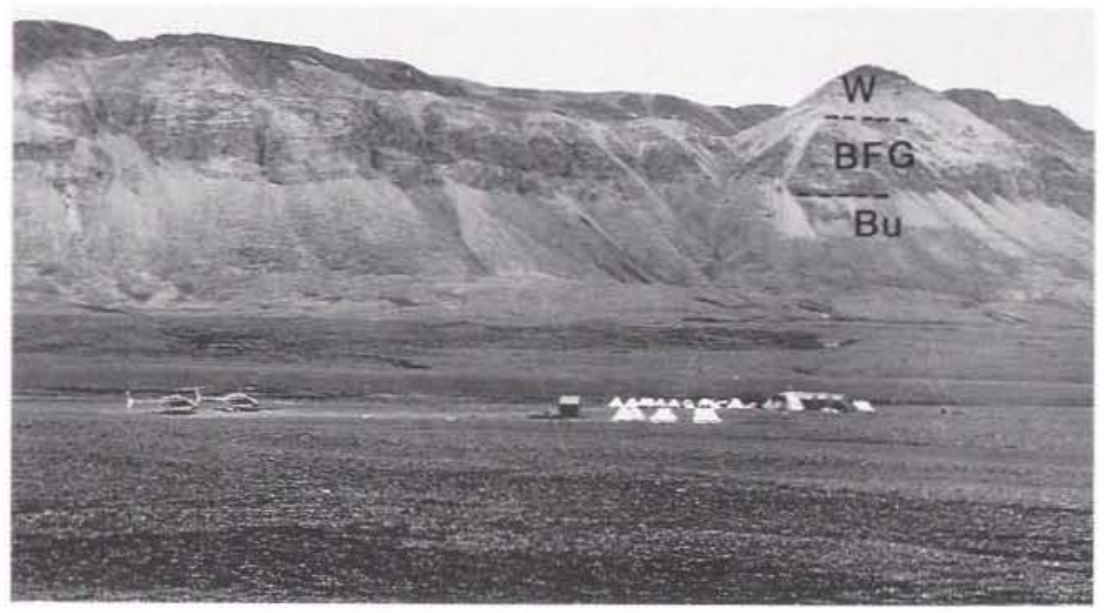

(Surlyk \& Hurst, 1984). Uplift in central and eastern North Greenland ceased sometime in the Early Ordovician, and was followed by regional marine transgression in the late Early Ordovician, probably partly as a result of a eustatic sea-level rise. The previously exposed eastern portion of the North Greenland shelf thus became part of a continuous, mainly low-energy shallow marine aggradational shelf, extending across North Greenland. Platform sedimentation in the east is recorded by the Wandel Valley Formation (late Early Middle Ordovician) and the Sjalland Fjelde Formation (early Middle Ordovician) of the Ryder Gletscher group (Figs 2, 4, 15, 17A, 20, 21, 30; Christie \& Peel. 1977; Ineson et al., 1986; Peel \& Smith, 1988). In the western areas the Cambrian aggradational shelf contin- ued its development into the Ordovician, as recorded by strata above the Permin Land Formation and its correlative Kap Coppinger Member (Figs 2, 4, 29, 31).

The Wandel Valley Formation $(320-410 \mathrm{~m})$ is dominated by pale dolomites. These may be burrow mottled with an irregular, parallel, discontinuous lamination, or exhibit cryptalgal and horizontal lamination, and wave and current formed cross-lamination, as well as dessication and water escape features. In the lower part of the formation dark, nodular, burrow mottled, pelletal lime mudstones containing Ceratopea and other gastropods are interbedded with the dolomites in 2-5 m, rarely up to $15 \mathrm{~m}$, thick shallowing upwards cycles (Hurst \& Surlyk, 1983b; Sønderholm \& Due, 1985; Peel \& Smith, 1988). The Wandel Valley Formation thus represents
Fig. 31. Restricted platform sediments of the Ryder Gletscher Group (stage $4 \mathrm{~S}_{2}$ ) east of the southern tip of Nares Land, showing the western extension of the sub-Wandel Valley Formation unconformity (u) within the Warming Land Formation (WA). Basal beds of the latter, and of the underlying Johansen Land $(\mathrm{J})$ and Permin Land (PL) Formations, are truncated over the crest of a shallow E-W trending anticline. $B_{3}$, Blue Cliffs Formation; SG, Steensby Gletscher Formation: CW, Cape Webster Formation. The Permin Land Formation is $23 \mathrm{~m}$ thick.

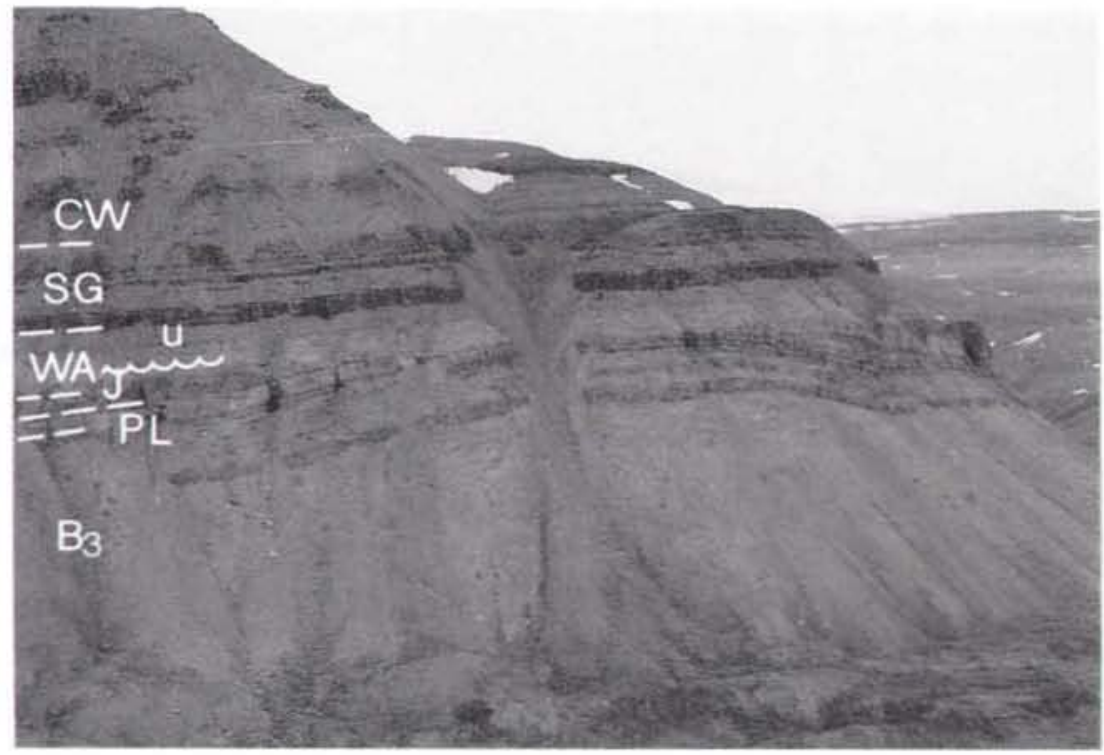


deposition in low-energy tidal flat and lagoonal environments on a slowly, but continuously subsiding platform.

In Kronprins Christian Land, the Wandel Valley Formation is overlain by the Sjælland Fjelde Formation $(105 \mathrm{~m})$ which in the lower part is dominated by bioturbated, skeletal lime mudstones and burrow mottled dolomites, with flat pebble conglomerates occurring throughout. The upper part is characterised by pale weathering, cryptalgally laminated dolomites. Spar-filled vugs and fenestrae, dessication cracks and stromatolite domes are common in places, as are bioturbation and halite pseudomorphs. The sediments reflect deposition in generally low-energy, shallow subtidal to low supratidal, locally evaporitic, environments (Ineson et al., 1986; Peel \& Smith, 1988).

The shallow marine sandstones of the Permin Land Formation in the western part of North Greenland mark a change from dominantly restricted carbonate platform deposits beneath (stage $4 \mathrm{~S}_{\mathrm{la}}$ ) to an alternation of restricted and more open marine carbonate facies above (stage $4 S_{2}$ ). This shift, which roughly coincides with the Cambrian-Ordovician boundary, was probably the result of a slight relative sea-level rise displacing the facies belts of the carbonate platform southwards.

The western part of the Ordovician succession assigned to the Ryder Gletscher Group can be regarded in terms of two major shallowing-upward cycles. Each cycle begins with carbonates, mainly of shallow subtidal aspect, which pass up into peritidal facies, often associated with evaporitic deposits. The thickness of these deposits increases from approximately $335 \mathrm{~m}$ in Nares
Land to $850 \mathrm{~m}$ in Washington Land, reflecting decreasing influence of the area of uplift in the Peary Land region.

The lower, dominantly subtidal portion of the first cycle is represented by the Johansen Land Formation $(15-35 \mathrm{~m})$ in central and more western parts of North Greenland (Figs 29, 31) and by the uppermost Cass Fjord (30 m), Cape Clay (50 m) and Christian Elv (140 m) Formations in Washington Land (Henriksen \& Peel, 1976; Sønderholm \& Due, 1985; Fig. 28B). These mainly comprise burrow-mottled, nodular dolomites and lime mudstones with subordinate wave and currentrippled lime grainstones and flat-pebble conglomerates. Occasional algally laminated dolomites, columnar stromatolites, scalloped surfaces and siliciclastic intervals in the Washington Land sequence reflect periodic shallowing into the intertidal zone.

The upper portion of this cycle in the Warming Land - Nares Land area (Warming Land Formation; 50-150 $\mathrm{m})$ consists of alternating dark and light grey finegrained dolomites showing current and wave-ripple cross lamination, flaser and wavy bedding and abundant bioturbation (Fig. 32). Scalloped surfaces, cryptalgal dolomites with desiccation cracks and gypsum nucleation cones pseudomorphed by chert occur in places. These sediments were deposited on prograding tidal flats, dominated by very shallow subtidal to supratidal, locally probably evaporitic, environments (Sønderholm \& Due, 1985). Farther west, in Washington Land, however, this interval is dominated by evaporitic deposits of the Poulsen Cliff (100-125 m) and Nygaard Bay $(40 \mathrm{~m})$ Formations (Figs 2, 4, 33) which are direct correlatives

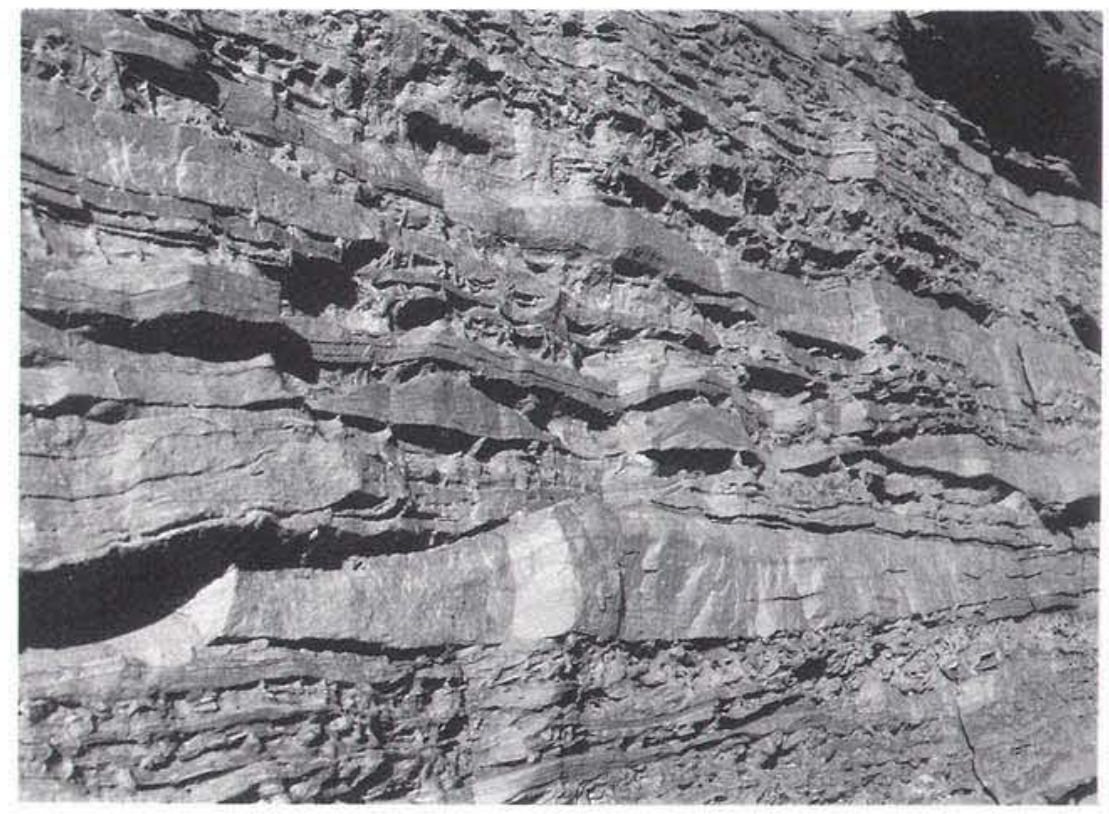

Fig. 32. Extensively burrowed, finegrained dolomite showing wavy and flaser bedding (Warming Land Formation, stage $4 S_{2}$ ). The ripples in the centre of the picture are $3 \mathrm{~cm}$ high Eastern Warming Land. 


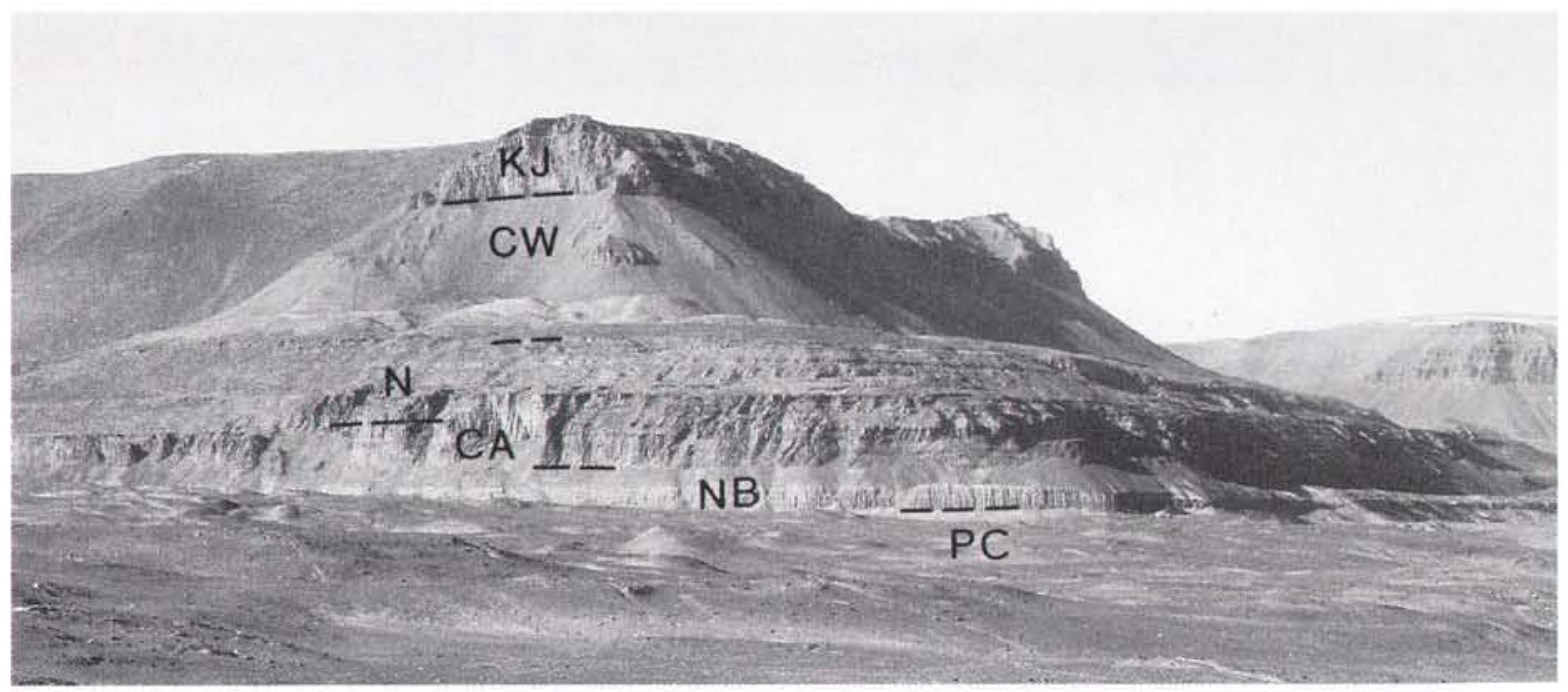

Fig. 33. Ryder Gletscher Group (stage $4 \mathrm{~S}_{2}$ ) overlain by the Kap Jackson Formation (KJ) of the Morris Bugt Group (stage $5 \mathrm{~S}_{1}$ ) in central Washington Land. The transition from recessive dolomitic sediments (stage $4 \mathrm{~S}_{2}$ ) to cliff-forming limestones $\left(\right.$ stage $\left.5 \mathrm{~S}_{1}\right)$ is a conspicuous marker traceable across most of the North Greenland shelf. PC: Poulsen Cliff Formation. N, Nunatami Formation; NB, Nygaard Bay Formation (45 m thick); CA, Canyon Elv Formation; CW, Cape Webster Formation.

of the thick evaporitic succession of Ellesmere Island (Baumann Fjord Formation; see Peel \& Christie, 1982). These gypsum deposits may show fine irregular lamination, current or wave-ripple lamination or may consist of nodular or nodular-mosaic gypsum (Fig. 34); they commonly occur interbedded with laminated shaly dolomites on a $10 \mathrm{~m}$ scale. By analogy with the Ellesmere Island deposits (cf. Trettin, in press) these evaporites are probably subaqueous deposits that accumulated in a broad, shallow, possibly segmented saline basin. The lower half of the Nygaard Bay Formation is dominated by dark limestones with intraformational conglomerate interbeds and is probably of shallow subtidal or intertidal origin.

The basal portion of the second cycle represents a marked transgression of probable eustatic origin which can be traced from Ellesmere Island (Eleanor River Formation; Barnes, 1984) across Washington Land (Canyon Elv and Nunatami Formations; $40-60 \mathrm{~m}$ and 150 $m$, respectively) and the rest of western and central North Greenland (Steensby Gletscher Formation; 90$135 \mathrm{~m}$ ) to eastern North Greenland (Wandel Valley Formation; $320-410 \mathrm{~m}$ ). In the west the basal part of the second shallowing upward cycle is typified by dark, thick-bedded, burrow-mottled lime mudstones containing a rich open-marine fauna. These low-energy, subtidal deposits are dominant, but pale dolomites, locally algally laminated and dessication cracked, occur in some southern localities and towards the top of the Nunatami and Steensby Gletscher Formations (Peel \&
Cowie, 1979; Sønderholm \& Due, 1985); they reflect periodic progradation of shallow subtidal to intertidal environments. The overlying Cape Webster Formation (175-280 m; see Fig. 33) marks the return to restricted conditions on the carbonate platform. It consists of grey to dark grey fine-grained dolomites with horizontal lamination, often with desiccation cracks and fluidisation features. Evaporites occur in the lower part of the formation in southern Washington Land and near the top in Nares Land, while breccias, possibly of solution origin, are common in Warming Land and central Washington Land (Sønderholm \& Due, 1985).

\section{T: Starved trough}

In southern Johannes V. Jensen Land the slope-andrise red and green coloured Frigg Fjord mudstones at the top of the Polkorridoren Group are overlain by an outer slope and trough-floor sequence including dark mudstones, cherts, turbidites and base-of-slope conglomerates (Surlyk \& Hurst, 1984). These upper Lower Cambrian to Lower Ordovician deposits are placed in the Vølvedal Group (Friderichsen et al., 1982; Surlyk et al., in prep.). The group differs markedly from the outer shelf and slope sequence described above by its much greater thickness, and by the presence of thick sandstone turbidite units. Higgins \& Soper (1985) suggested that the turbidites of the Vølvedal Group did not extend much beyond the west point of Amundsen Land; it is possible that these deposits were in fact restricted to 


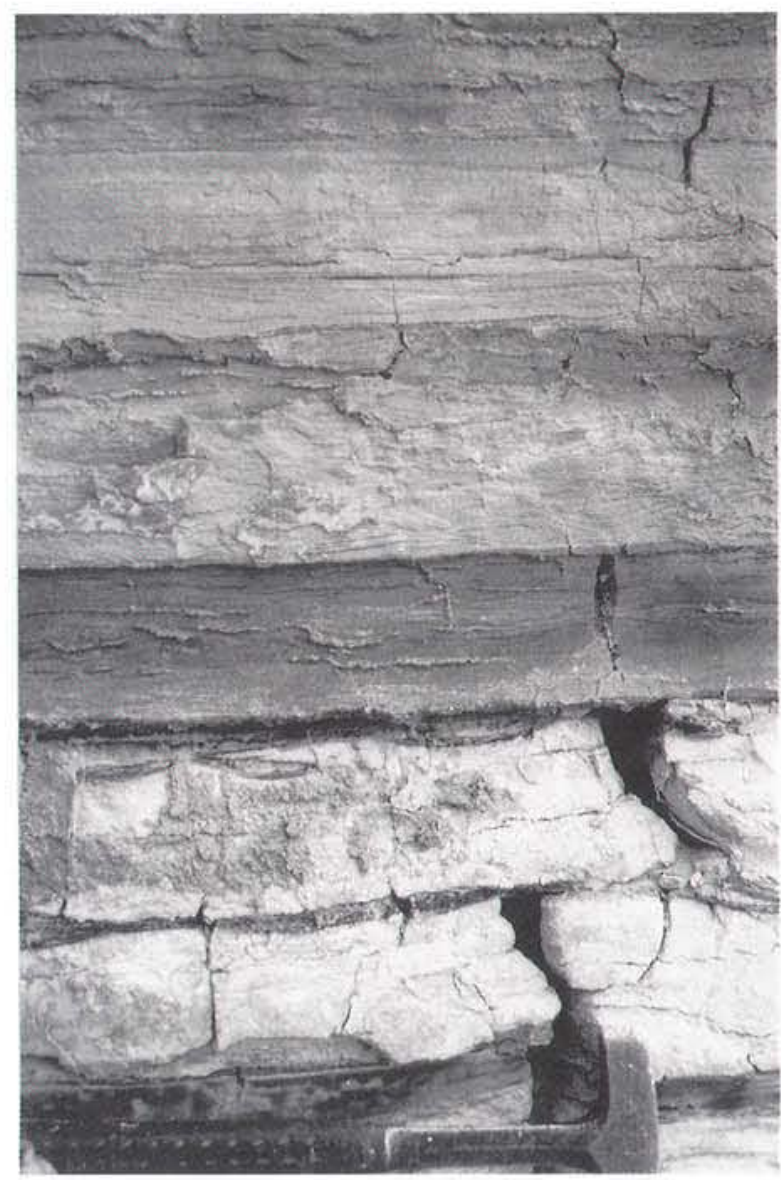

Fig. 34. Irregularly laminated, current and wave laminated, and massive gypsum deposits of the Poulsen Cliff Formation (stage $4 \mathrm{~S}_{2}$ ). Hammer for scale. Central Washington Land.

the eastern part of the trough, if their deposition was linked to uplift of eastern areas in the Cambrian as suggested by Surlyk \& Hurst (1984). However, the absence of outcrops of the trough sequence in Nansen Land makes this difficult to verify, and farther west in western North Greenland, this part of the basin is situated north of the present-day land areas. Comparable turbidites are not known from equivalent strata of the Hazen Formation in the outcrops of north-east Ellesmere Island.

The present outcrops of the Vølvedal Group are almost confined to southern Johannes V. Jensen Land, including Amundsen Land, and the region adjacent to Frederick E. Hyde Fjord (Fig. 35; Map 1). The group is generally $600-700 \mathrm{~m}$ thick. It begins with dark-grey and black non-bioturbated mudstones with thin-bedded turbidites comprising the Nornegæst Dal Formation. Deposition of the formation took place on the trough floor under poorly aerated conditions. Fine-grained sedimentation continued in the form of greenish chert, cherty mudstones and siltstones, locally with fine sandstone turbidites. These deposits form the approximately $50 \mathrm{~m}$ thick Drengs Bræ Formation.

The quiet, partly anoxic trough floor sedimentation was eventually interrupted by the influx from the south of medium-bedded to thick-bedded quartzitic turbidites of the Bøggild Fjord Formation (Fig. 36). The turbidites alternate with thin beds of black mudstones. The formation is approximately $240 \mathrm{~m}$ thick and is interpreted as representing one or more relatively small borderland fans prograding northwards into the trough, where black and green bedded cherts and black mudstones with thin-bedded fan fringe and basin-plain turbidites were deposited. The more proximal southern occurrences display channellised mid-fan and outer fan lobe features, and the turbidite units decrease dramatically in bed thickness and in sand/mud ratio towards the north (Fig. 37).

Along strike the fan turbidites pass into interfan mudstones of the trough floor. All mudstones and finegrained, thin-bedded turbidites are chertified to varying degrees. In many cases the chertification is so intense that the original turbidite features are completely masked.

Towards the end of submarine-fan deposition the upper slope underwent slumping on a large scale. A composite debris sheet in southern Johannes V. Jensen Land is up to $20 \mathrm{~m}$ thick and can be traced along strike for $75 \mathrm{~km}$. The mainly clast-supported conglomerates are composed largely of tabular, angular clasts of laminated carbonate that range in size from pebbles to boulders up to $1 \mathrm{~m}$ long, set in a lime mudstone matrix. Clasts often show varying degrees of plastic deformation, indicating that the parent rock was only partially lithified at the time of slumping and subsequent massflow transport. Clast lithologies suggest derivation from the upper slope and outer shelf rather than from the carbonate platform. One conspicuous boulder type comprises alternations of grey limestone and yellow dolomite, known to form thick developments in the equivalent Cambrian sequence of the outer shelf and slope (Kap Stanton Formation of the Tavsens Iskappe Group; unit 3 of Higgins \& Soper, 1985).

There is little faunal control of the age of the Vølvedal Group, and the late Early Cambrian age of the base is fixed by comparison with the outer shelf and slope deposits. Early Ordovician graptolites are fairly common in mudstones in the middle and upper levels of the group.

A local development of the submarine fan sequence occurs in southern Johannes V. Jensen Land. It consists of thin to medium-bedded calcarenitic turbidites, carbonate conglomerates and black shales. The carbonate 
Fig. 35. North side of O. B. Bøggild Fjord showing turbidites of the $\mathrm{V} \emptyset \mathrm{I}-$ vedal Group (VG, stage 4T), overlain by black cherts and shales with carbonate and chert conglomerates of the Amundsen Land Group (AG, stage $5 \mathrm{~T}$ ), and by turbidites of the Merqujôq Formation, Peary Land Group (PL, stage 6T).

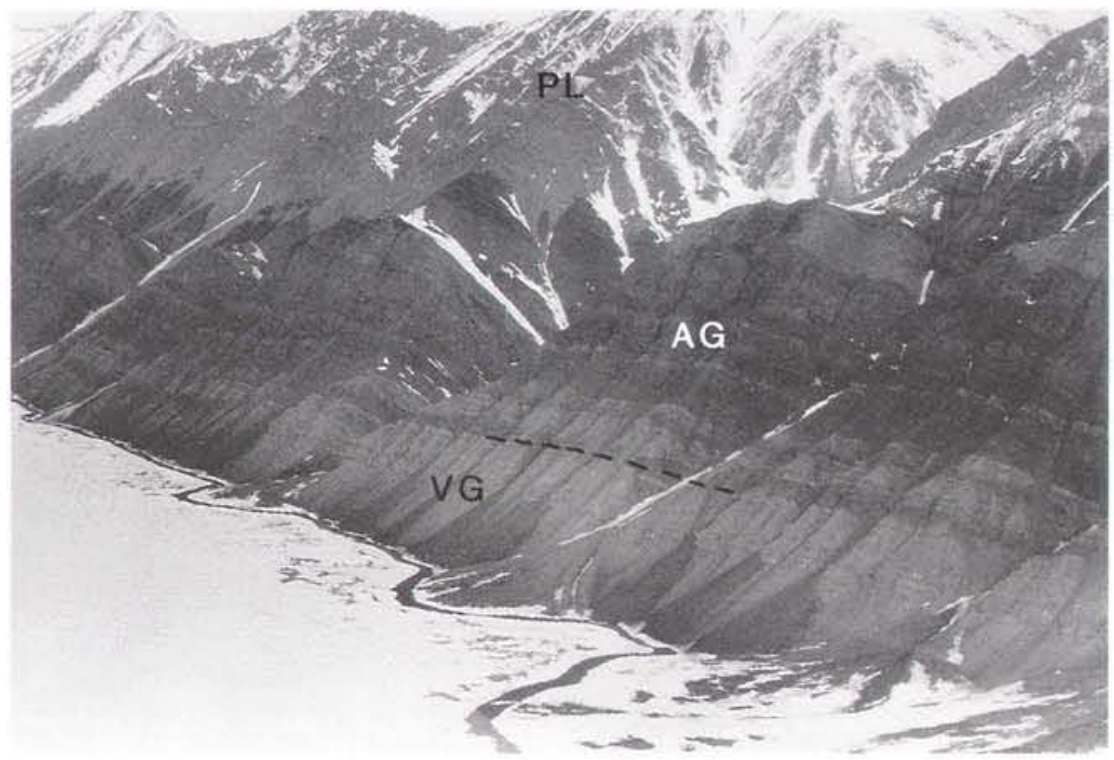

dominated lithology probably reflects the progressive uplift and erosion of the eastern platform region.

\section{Stage 5: Middle Ordovician - Early Silurian aggradational carbonate platform, starved slope and trough}

This stage in basin evolution is marked by a backstepping of the platform margin to approximately the line of the Navarana Fjord escarpment (Figs 3, 5; stage 5). Aggradational carbonate deposition continued to build up on the platform to the south with the platform margin forming a scarp-like feature (Figs 4,38 ). North of the scarp the slope was starved receiving very restricted amounts of sediment. Farther north, in the deep-water trough, deposition was also slow, but considerably greater than in the slope areas. The relatively starved phase of slope and trough deposition lasted until the close of the Ordovician, when it was terminated by the abrupt commencement of turbidite deposition of the Peary Land Group (stage 6T).
Fig. 36. Stacked, thinning-upwards turbidite sequences representing mid-fan channels. Vølvedal Group (stage 4T), O. B. Bøggild Fjord. Person for scale (ringed).

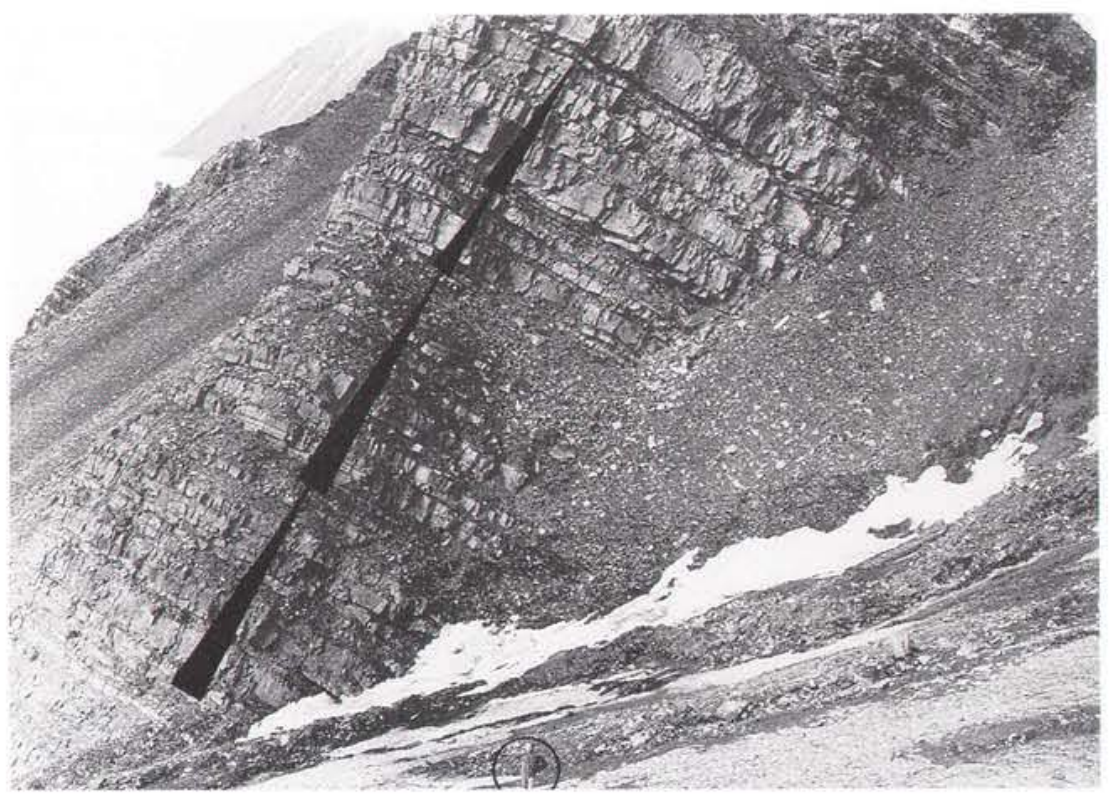




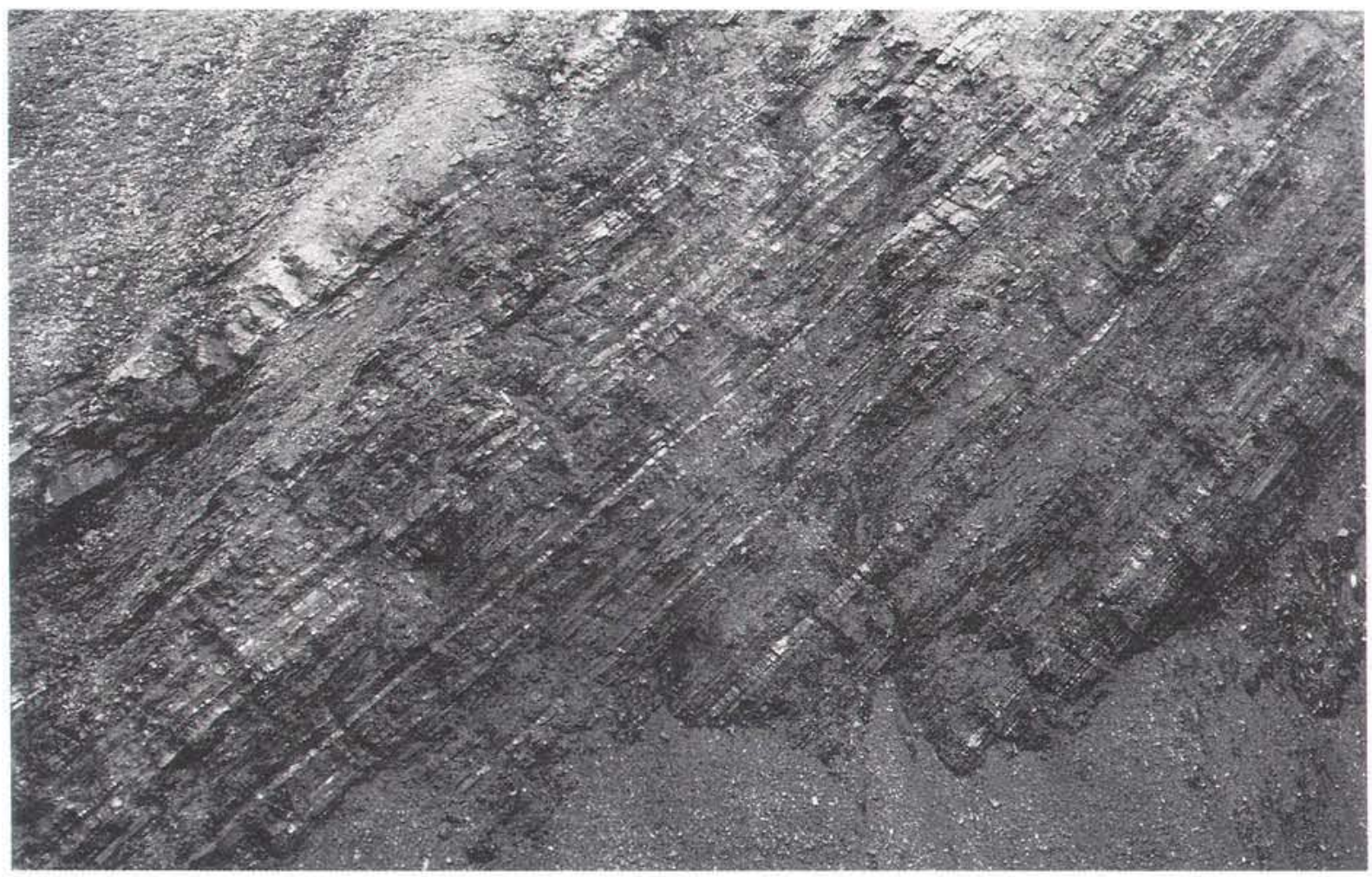

Fig. 37. Fan fringe and basin plain turbidites, black cherts and mudstones of the Vølvedal Group, stage 4T. Johannes V. Jensen Land. Thickness of consistent light beds in the middle of the section is about $10 \mathrm{~cm}$.

\section{S 1 : Aggradational platform}

The phase in the evolution of the shelf recognised as stage 5 commenced with the late Middle Ordovician transgression (Christie \& Peel, 1977; Fortey, 1984) and persisted into the Early Silurian (Early to Middle Llandovery). It is represented by the Morris Bugt Group and the basal part of the Washington Land Group (Hurst, 1980a; Hurst, 1984; Sønderholm et al., 1987; Smith et al., 1989, Sønderholm \& Harland, in prep.) (Figs 2, 4).

The constant total thickness of these carbonate units throughout the region $(c .650 \mathrm{~m})$ reflects uniform subsidence over the area (Smith et al., 1989).

The shelf was bounded by an escarpment hundreds of metres high which can be seen in the inner parts of Navarana Fjord and at J. P. Koch Fjord (Fig. 38), where it forms an erosional sediment by-pass zone (Surlyk \& Hurst, 1984; Surlyk \& Ineson, 1987a). The extension of the escarpment further to the west as far as northern Nyeboe Land and north of Hall Land is inferred from stratigraphic considerations and from changes in the style of tectonic deformation (Escher \& Larsen, 1987; Hurst \& Surlyk, 1982; Larsen \& Escher, 1985). Hurst \&
Kerr (1982) suggested that the isolated outcrop of carbonates around Kap Ammen in northern Hall Land (Figs 1, 2,39) represented an Early Llandovery carbonate horst surrounded by deep-water shelf clastic sediments. However, the presence of the same facies and lithostratigraphic units in the southern part of Nyeboe Land seems to indicate that the carbonate shelf extended unbroken from the southern outcrop belt to northern Hall Land and Nyeboe Land until late in the Middle Llandovery (Dawes \& Peel, 1984; Sønderholm et al., 1987).

The shelf margin itself is only clearly exposed in the inner parts of J. P. Koch Fjord and Navarana Fjord (Figs 38,40 ) and these outcrops also closely resemble the equivalent exposures at Kap Ammen in northern Hall Land (Fig. 39). Hurst \& Surlyk (1983b) described mud mounds up to $200 \mathrm{~m}$ in diameter and $50-100 \mathrm{~m}$ high from the shelf margin at J. P. Koch Fjord. The mounds apparently had considerable relief above the surrounding level-bedded sediments.

Elsewhere in Peary Land, shelf margin facies equivalent to the Tures $\varnothing$ Formation are only known from large blocks contained in contemporaneous base-ofslope conglomerates of the Citronens Fjord Member 
(Figs 2-4), occurring along the southern coast of Frederick E. Hyde Fjord (Hurst \& Surlyk, 1982; Hurst, 1984). The boulders consist of distinctive lithoclasticbioclastic grainstones rich in fragments of virgianid brachiopods, stromatoporoids, gastropods and algae. Some small dolomite clasts are red stained. This suggests that the shelf was rimmed by high energy carbonate sand shoals; the abundance of algae may indicate the presence of algal reefs well within the photic zone with possible episodes of subaerial exposure (Hurst, 1984).

The sediments of the Kap Jackson Formation, together with the Cape Calhoun Formation and the Newman Bugt Member of the Aleqatsiaq Fjord Formation with a total thickness ranging from 300 to $390 \mathrm{~m}$, and the corresponding Børglum River Formation (approximately $430 \mathrm{~m}$ ) (Figs 2, 4, 38, 41) are dominantly dark, nodular, burrow mottled lime mudstones, skeletal wackestones and packstones. Epifauna and infauna are abundant and algal remains are common. These levelbedded sediments are of typical subtidal carbonate shelf aspect. The lack of grainstones suggests low energy environments probably below normal wave base, while the abundant fauna and algae indicate an oxygenated substrate within the euphotic zone.

This stable and uniform phase of deposition came to an end in latest Ordovician to earliest Silurian time as a result of a pronounced shallowing, followed by a later deepening of the entire shelf. The event is represented by the upper two units (the Kap Ammen and Store Canyon Members; $115-160 \mathrm{~m}$ ) of the Aleqatsiaq Fjord Formation (Sønderholm \& Harland, in prep.) and the $115-150 \mathrm{~m}$ thick Tures $\emptyset$ Formation (Figs 2, 4; Hurst, 1984). The great lateral extent of these units and the timing of the shallowing and deepening may indicate eustatic events related to the late Ordovician glaciation (Brenchley \& Newall, 1980; Fortey, 1984; McKerrow, 1979). The Kap Ammen Member of the Aleqatsiaq Fjord Formation consists of light grey, massively bedded, variably biostromal and coralliferous skeletal limestones. In situ stromatoporoids and corals are locally very abundant and contribute to the formation of small mounds in some areas, e.g. Bessels Fjord, Petermann Fjord, Newman Bugt and Kap Ammen (Fig. 39) (Sønderholm \& Harland, 1989a). The sediments are interpreted as being of agitated, shallow, open shelf origin, reflecting a relative lowering of sea-level compared to the underlying unit. Towards the east, in the Nares Land to J. P. Koch Fjord region, the Kap Ammen Member becomes progressively more dolomitic and less fossiliferous, suggesting a more restricted environment (Sønderholm et al., 1987). Farther to the east in Peary Land, it grades into the light weathering dolomites of the lower part of the Tures $\varnothing$ Formation (Hurst, 1984).
The Tures $ø$ Formation in central Peary Land displays a well developed cyclicity (Fig. 42), each cycle varying from 2 to $20 \mathrm{~m}$ in thickness and consisting of burrow mottled, dolomitic wackestones with occasional calcsiltripples and rare benthic fauna, overlain by laminated and cryptalgally laminated or fenestral dolomites (Armstrong \& Lane, 1981; Fürsich \& Hurst, 1980; Hurst, 1984). The scarcity of intraclast conglomerates and shelly coquinas suggests that the whole succession was formed under very low energy conditions, and the possibility of periodically raised salinities has been discussed (Fürsich \& Hurst, 1980; Hurst, 1984). In the G. B. Schley Fjord region to the north-east the environment again became more open marine. Here, the Tures $\emptyset$ Formation is darker, less dolomitic and consists almost entirely of nodular lime wackestones.

The deepening which followed this phase of shallowwater deposition is represented by the sediments of the Store Canyon Member of the Aleqatsiaq Fjord Formation in the Washington Land to J. P. Koch Fjord region (Fig. 39) and the upper part of the Turesø Formation in Peary Land and Kronprins Christian Land (Figs 2, 4, 42). The Store Canyon Member is uniformly developed over the entire area and comprises very dark, strongly mottled, bituminous, fine-grained skeletal limestones with abundant large pentamerid brachiopods and frequent stromatoporoids and corals of Silurian age (Fig. 43). These sediments originated on an open, mainly low-energy, shelf. The upper part of the Tures $\varnothing$ Formation in central Peary Land consists of dolomites much like the lower unit but dominated by the darker subtidal facies (Armstrong \& Lane, 1981; Christie \& Peel, 1977; Hurst, 1984). To the north-east, in the G. B. Schley Fjord region, the upper part of the Tures $\emptyset$ Formation is more reminiscent of the Store Canyon Member of the Aleqatsiaq Fjord Formation, again suggesting a deepening of the shelf towards the east (Christie \& Ineson, 1979).

This phase in the evolution of the stable platform came to a close during the Early Silurian which was a period of general shallowing of the platform sea, probably due to rapid vertical accretion. This period is represented by the Ymers Gletscher Formation in Peary Land, the Petermann Halvø Formation between J. P. Koch Fjord and Bessels Fjord (Fig. 39, see also Fig. 46) and parts of the Kap Godfred Hansen, Pentamerus Bjerge and Adams Bjerg Formations (Figs 2, 4) (Hurst, 1984; Sønderholm \& Harland, in prep.).

The Ymers Gletscher Formation (25-45 m) comprises grey, thinly laminated and well bedded fenestral lime mudstones. Coquinas dominated by pentamerid brachiopods are present as well as desiccation cracks (Armstrong \& Lane, 1981; Hurst, 1984). The sediments re- 


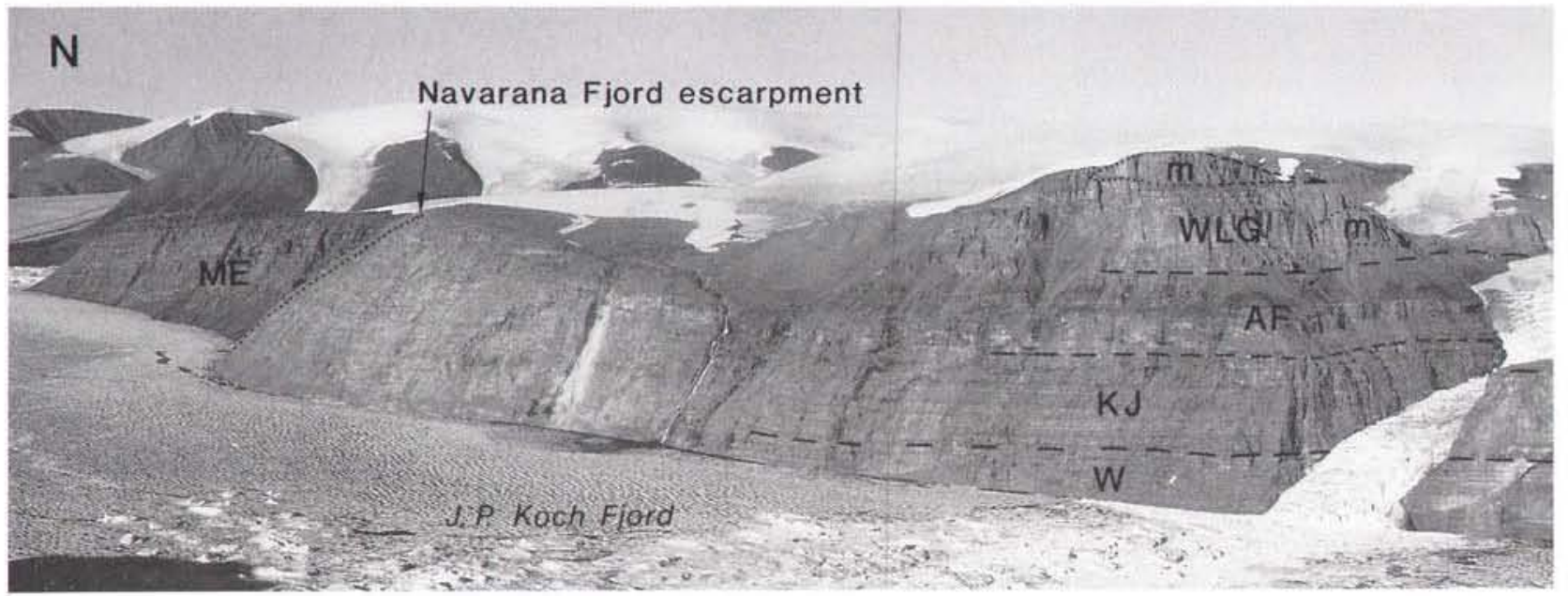

Fig. 38. Platform margin escarpment (Navarana Fjord escarpment) on the east side of J. P. Koch Fjord. Sandstone turbidites of the Merqujôq Formation (ME, stage $6 \mathrm{~T}$ ) abut against platform carbonates of stages $5 \mathrm{~S}_{1}$ and $6 \mathrm{~S}$ forming the escarpment. Note that bedding in the carbonates becomes diffuse as the escarpment is approached. W, Wandel Valley Formation, Ryder Gletscher

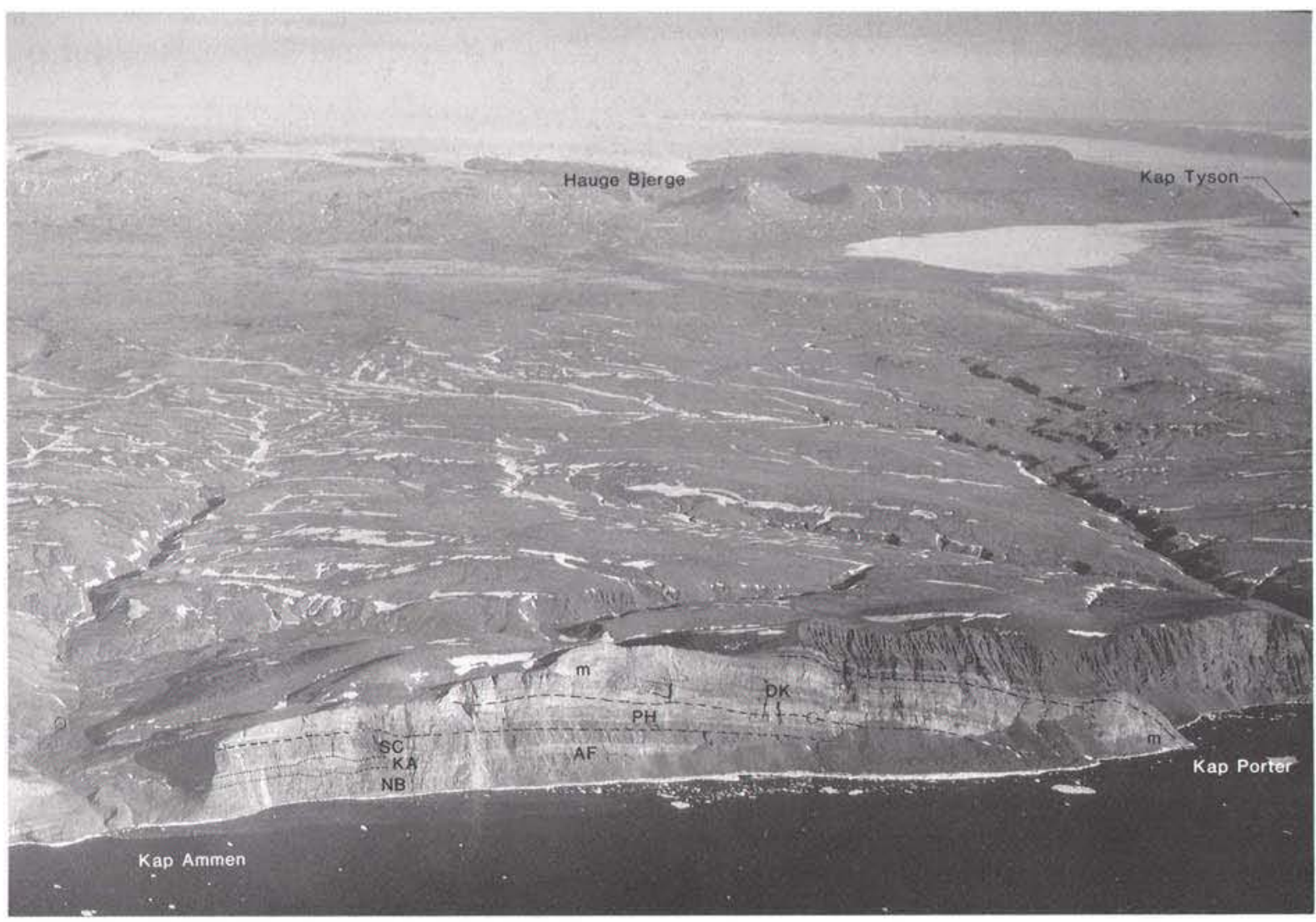

Fig, 39. Carbonate shelf sequence (stage $5 \mathrm{~S}_{1}$ and $6 \mathrm{~S}$ ) at Kap Ammen, northern Hall Land close to the shelf margin. Dark open marine deposits of the Store Canyon Member (SC) of the Aleqatsiaq Fjord Formation (AF), are overlain by pale carbonates of the Petermann Halvø Formation (PH). Shelf edge mounds (m) with intermound deposits make up the overlying Djævlekløften Formation (DK). The shelf carbonates are overlain by deep sea fan turbidite sequences of the Peary Land Group (PL; stage 7T). In the distance, a linear belt of reefs (stage 7S) forms the Hauge Bjerge. KA, Kap Ammen Member; NB, Newman Bugt Member. Aerial photograph 546 K-S no. 2190. Copyright Kort- og Matrikelstyrelsen, Denmark; reproduced with permission A.200/87. 


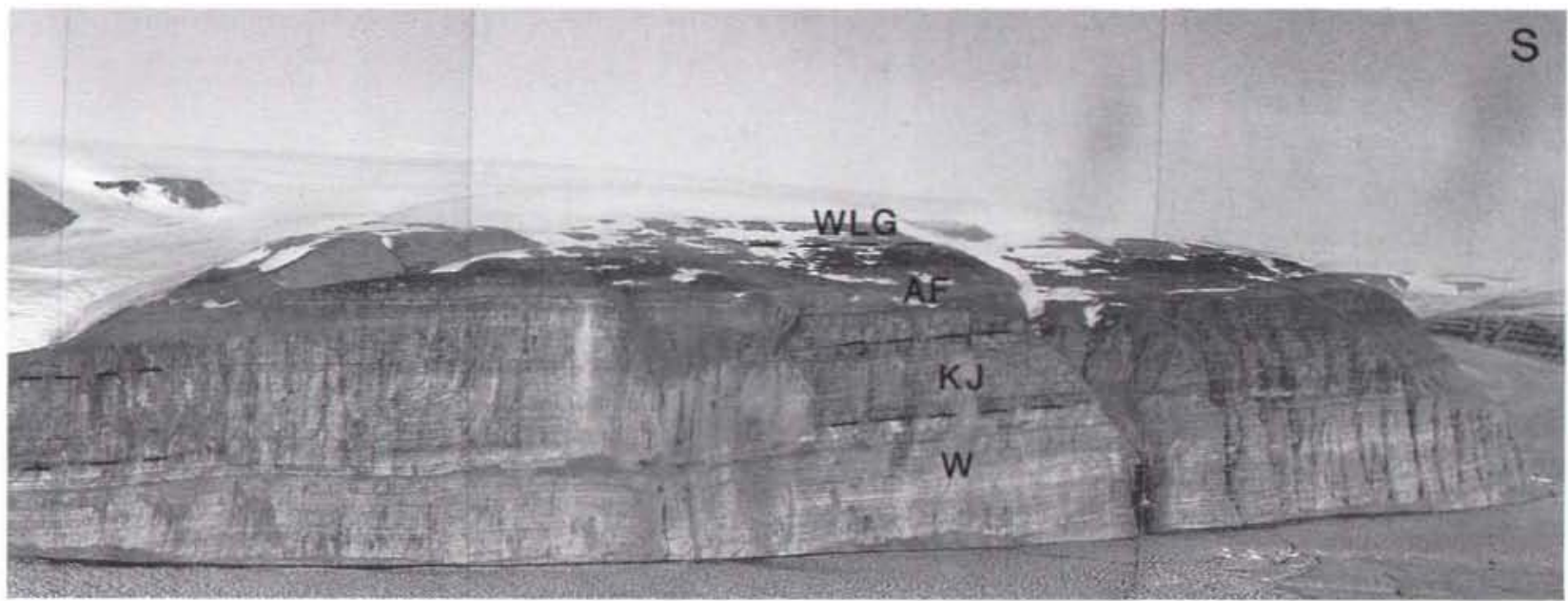

Group (stage $4 \mathrm{~S}_{2}$ ); KJ, Kap Jackson Formation (stage $5 \mathrm{~S}_{1}$ ); AF, Aleqatsiaq Fjord Formation (stage $5 \mathrm{~S}_{1}$ ); WLG, Washington Land Group (stage $5 \mathrm{~S}_{1}$ and $6 \mathrm{~S}$ ) with small mounds $(\mathrm{m})$. Cliff $800 \mathrm{~m}$.

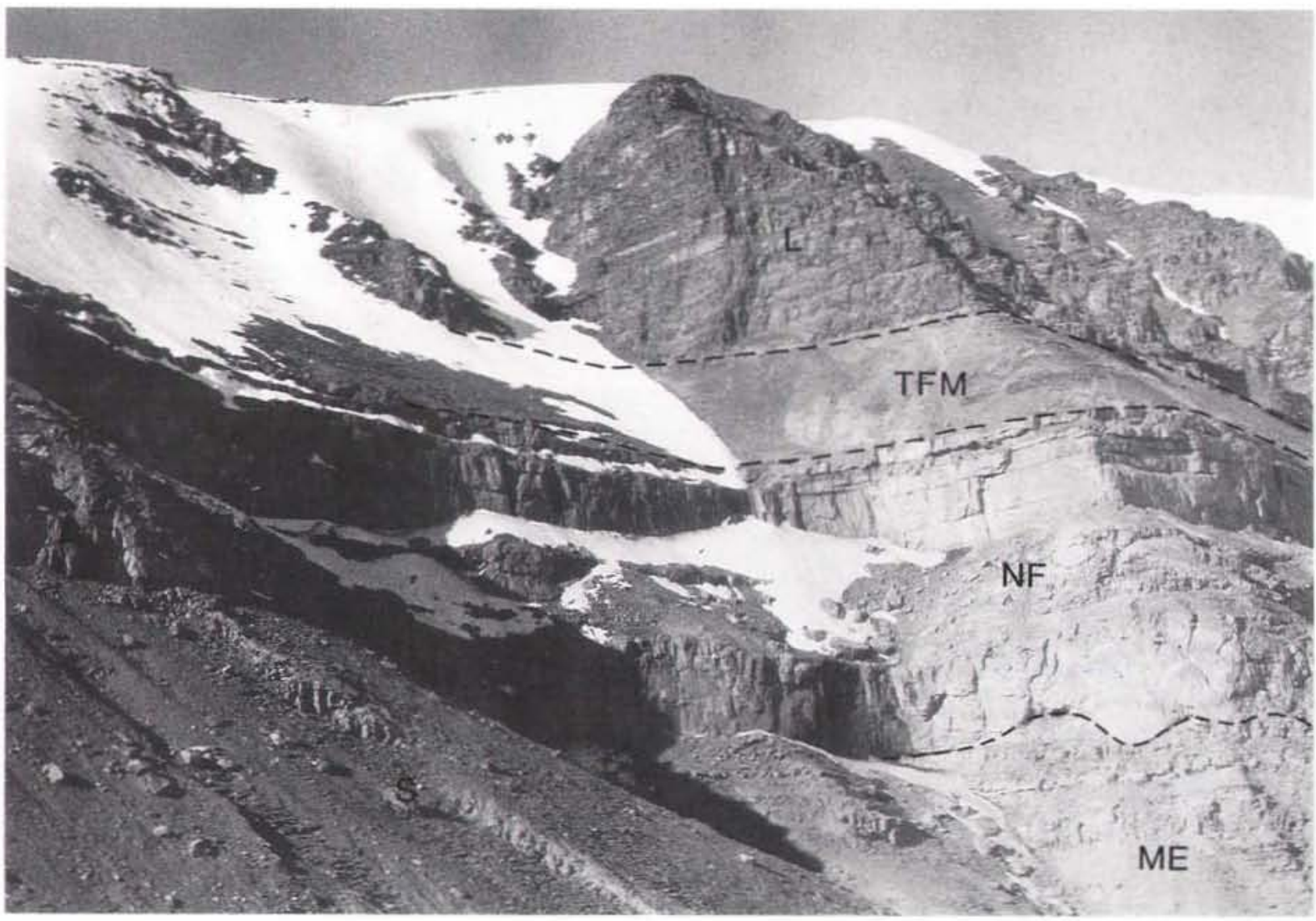

Fig. 40. Platform margin relationships on the west side of Navarana Fjord. Top of the drowned Silurian platform margin scarp to the left (S, stage 6S), onlapped by turbidites of the Merqujôq Formation to the right (ME, stage 6T). Carbonate conglomerates of the Navarana Fjord Member (NF) drape the platform carbonates, interfinger with the highest turbidites of the Merqujô Formation and are overlain by black shales and thin-bedded turbidites of the Thors Fjord Member (TFM) of the Wulff Land Formation and turbidites of the Lauge Koch Land Formation (L, stage 7T). The thickness of the Navarana Fjord Member is $80 \mathrm{~m}$. 


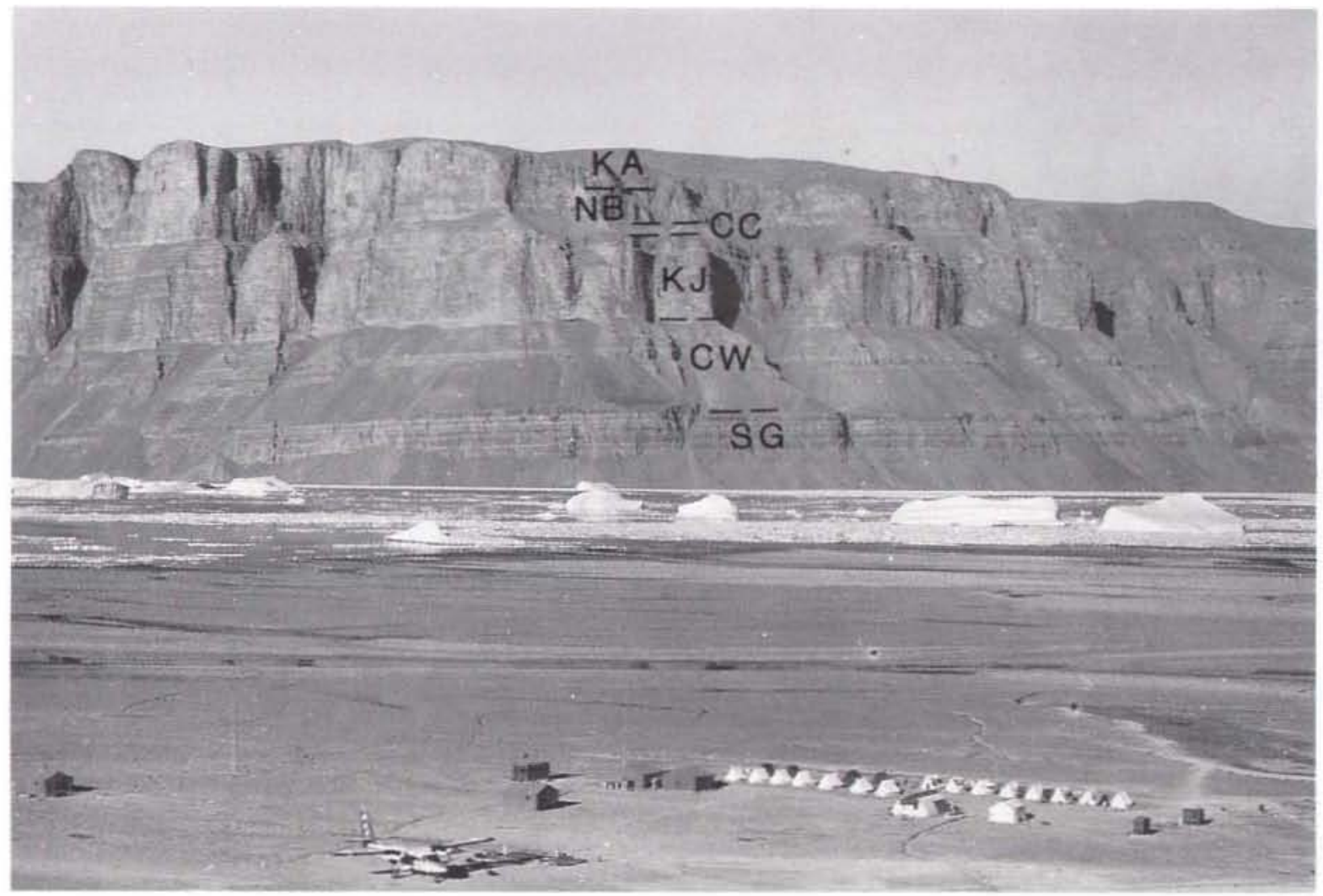

Fig. 41. Dark, cliff-forming carbonates of the Morris Bugt Group, representing the open marine shelf deposits of stage $5 \mathrm{~S}_{1}$. KJ, Kap Jackson Formation; CC, Cape Calhoun Formation; NB, KA, Newman Bugt and Kap Ammen Members of the Aleqatsiaq Fjord Formation. The Steensby Gletscher (SG) and Cape Webster (CW) Formations of the Ryder Gletscher Group (stage 4S ) form the lower half of these $700 \mathrm{~m}$ high cliffs in southern Permin Land. Base camp of the Geological Survey of Greenland expedition $1984-85$ in foreground.

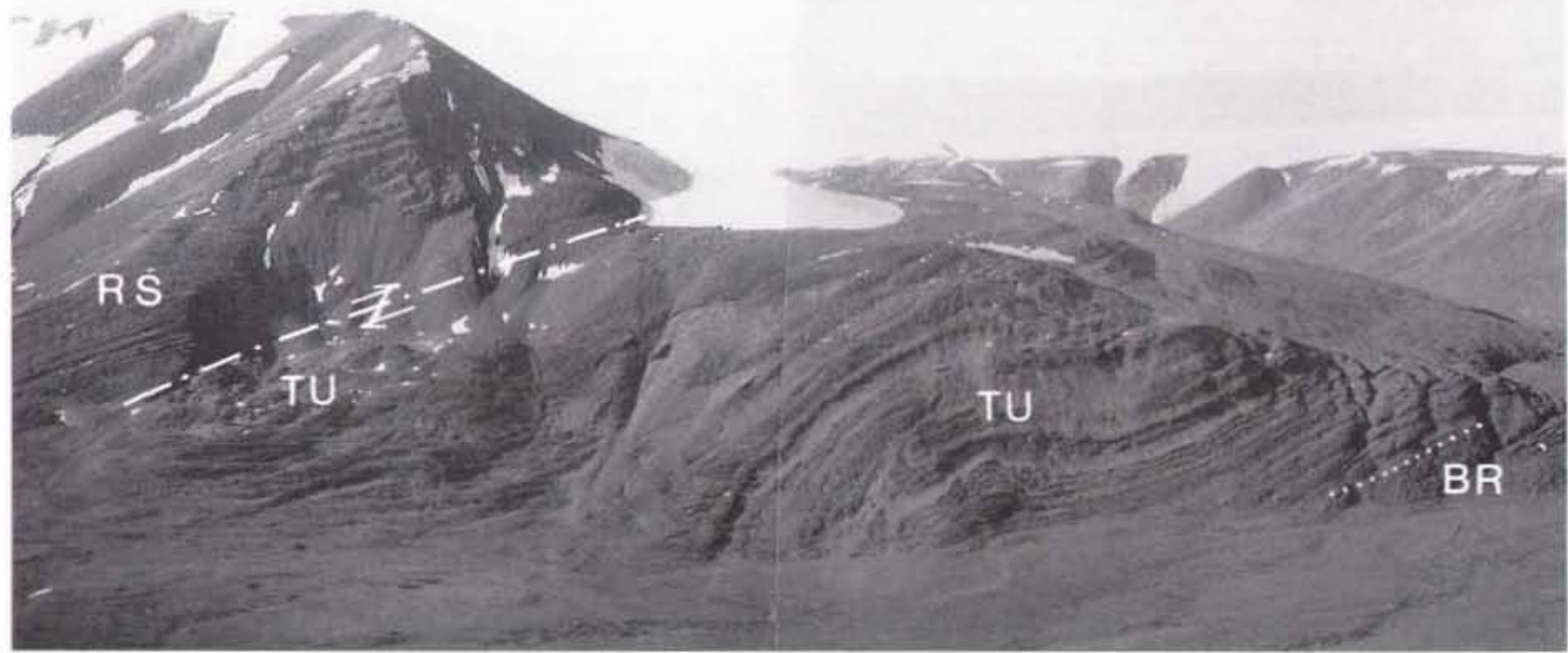

Fig. 42. Alternations of pale and dark coloured dolomitic limestones of the Turesø Formation (TU) overlying dark limestones of the Børglum River Formation (BR), central Kronprins Christian Land (both stage $5 S_{1}$ ). Caledonian deformation has disturbed the sequence, and emplaced a thrust sheet of Proterozoic sandstone turbidites (RS: Rivieradal Sandstone) over the Turesø Formation. Cliff height $800 \mathrm{~m}$. 


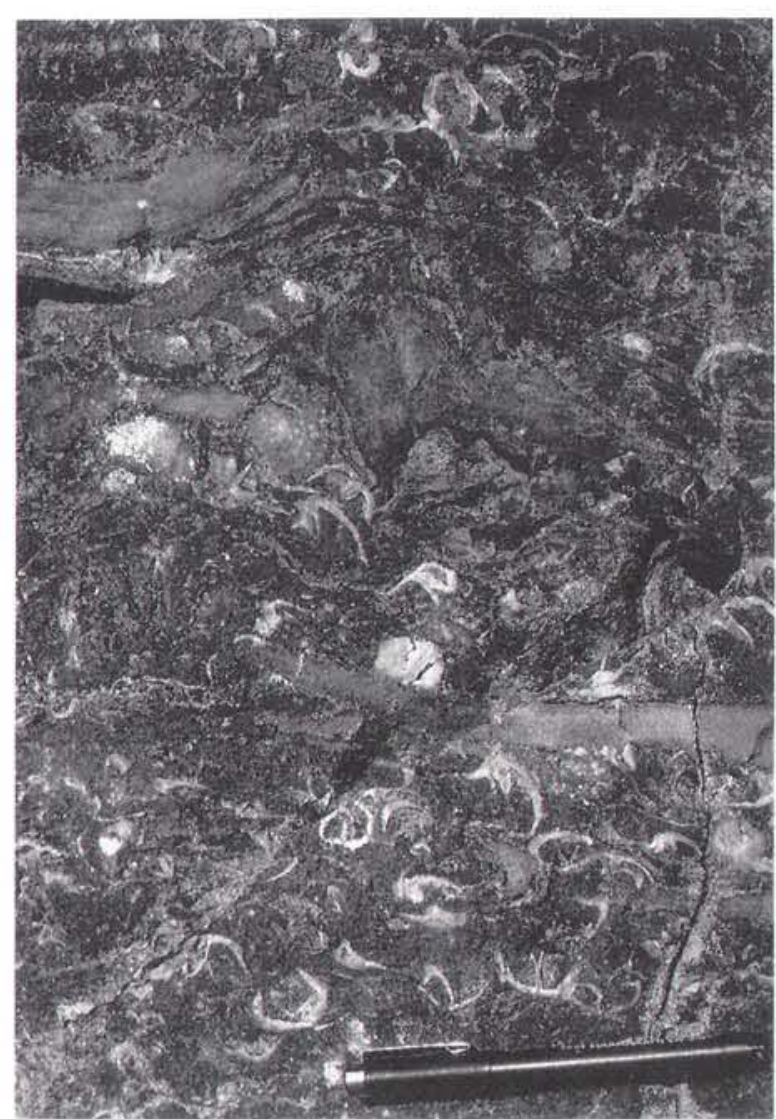

Fig. 43. Strongly mottled, bituminous skeletal pentamerid limestone with frequent stromatoporoids (Aleqatsiaq Fjord Formation, Store Canyon Member, stage $5 S_{1}$ ). Pencil is $15 \mathrm{~cm}$ long.

flect deposition in peritidal environments, possibly with raised salinities (Fürsich \& Hurst, 1980). The sediments of the Petermann Halvø Formation $(95-130 \mathrm{~m})$ are dominated by light grey to dark, flat-bedded, skeletal limestones, usually rich in laterally extensive coral and stromatoporoid colonies with locally abundant crinoid debris. Facies variations within the Petermann Halvø Formation, reflect a slight deepening from peritidal, possibly partly emergent environments, in the south, to shallow outer platform in the north. Peritidal environments represented by cryptalgally laminated dolomites have only been recorded from the lower part of the Adams Bjerg Formation farthest to the south-west (Hurst, 1980a; Sønderholm et al., 1987; Sønderholm \& Harland, in prep.).

\section{$5 S_{2}:$ Starved slope}

The outer shelf and slope carbonates and mudstones of stage $4 \mathrm{~S}_{\mathrm{ip}}$ between northern Nyeboe Land and cen- tral J. P. Koch Fjord are overlain by a sequence of chert and cherty shales, with partly chertified successions of siltstones, black limestones and dolomitic mudstones (Fig 9; unit 4 of Higgins \& Soper, 1985). This starved slope sequence is generally between $50 \mathrm{~m}$ and $150 \mathrm{~m}$ in thickness, and is assigned to a new formation of the Amundsen Land Group. Rich graptolite faunas occur throughout, and show an age range from Tremadoc to Late Llandovery.

Throughout the area between northern Nyeboe Land and central J. P. Koch Fjord, chert and mudstone deposition was brought to a close in the Late Llandovery with the incoming from the east of the first sand turbidites of the Peary Land Group (Higgins \& Soper, 1985; Surlyk, 1982; Surlyk \& Hurst, 1982). Deposition of fine grained turbidites was initiated slightly earlier, in latest Ordovician time towards the east in the Peary Land area. These distal turbidites are interbedded with black mudstones and cherts characteristic of stage 5T and they are accordingly not included in the Peary Land Group (Hurst \& Surlyk, 1982; Surlyk et al., 1980; Surlyk et al., in prep.).

The Ordovician starved slope sequence passes downslope into similar, but more basinal and more thickly developed sediments of the same age which are only preserved in the type area of the Amundsen Land Group.

\section{T: Trough}

The relatively small-sized borderland fans of the Vølvedal Group (stage 4T) were eventually abandoned and a long period of basin starvation and, at times, also stagnation set in (Surlyk \& Hurst, 1984). In southern Johannes V. Jensen Land, including Amundsen Land, and the areas along the south side of Frederick E. Hyde Fjord, the deposits of this period are included in the Early Ordovician - Early Silurian Amundsen Land Group (Friderichsen et al., 1982; Surlyk et al., in prep.). The sedimentary facies are dominated by black and green radiolarian cherts and black and green mudstones; they include thin-bedded turbidites and thick carbonate conglomerates.

Turbidite deposition of the previous stage (Bøggild Fjord Formation of the Vølvedal Group) rapidly waned, and stage $5 \mathrm{~T}$ was heralded by a change to slow sedimentation of mud and siliceous ooze mainly under anoxic conditions (Harebugt Formation of the Amundsen Land Group). In latest Tremadoc and Arenig times the quiet deposition of fine-grained sediments was interrupted by a period dominated by deposition of carbonate conglomerates and turbidites of the Kap Mjølner Formation which reaches a thickness of up to $200 \mathrm{~m}$ 


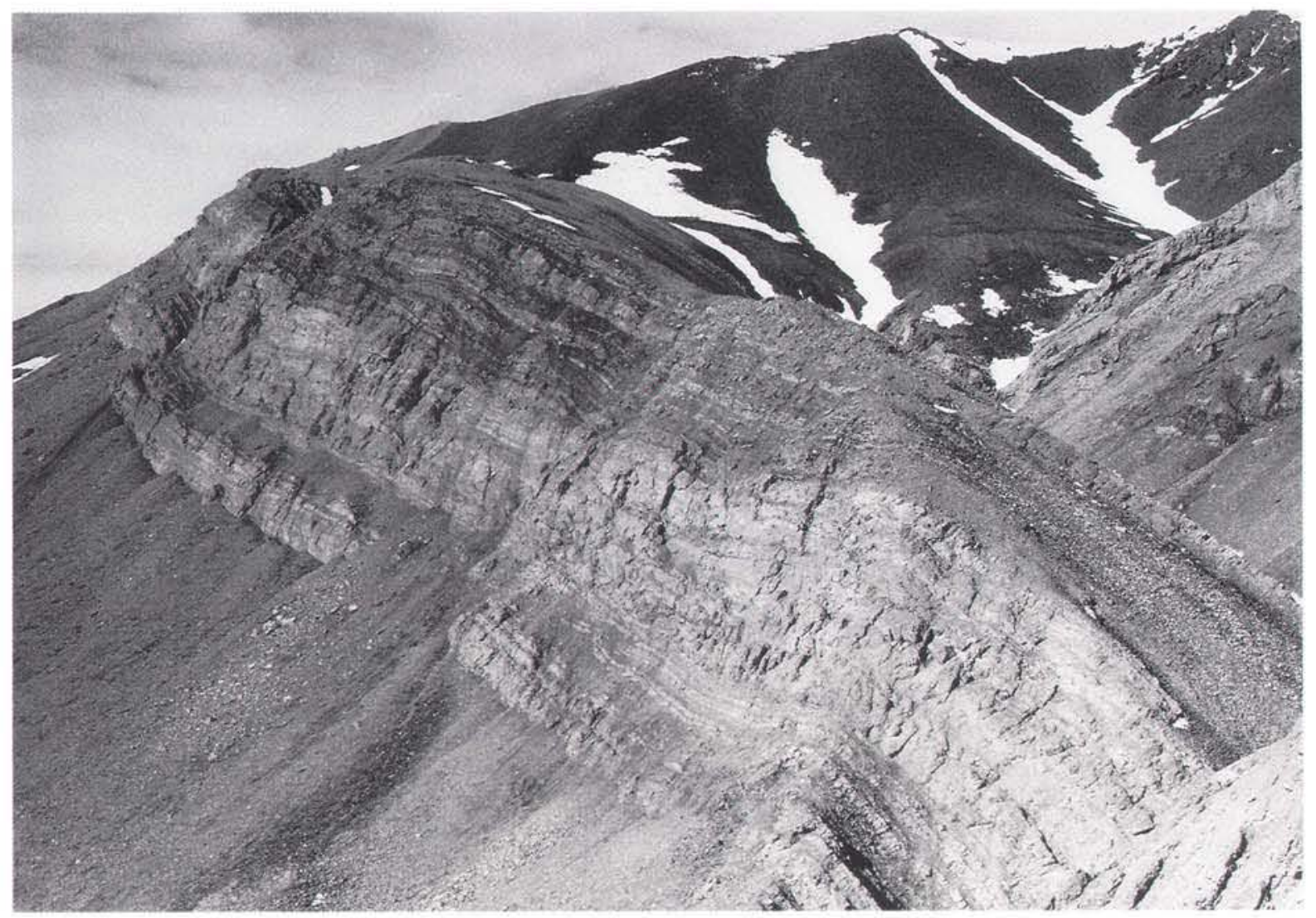

Fig. 44. Sheet of base-of-slope carbonate conglomerates and calcarenites in the lower part of Amundsen Land Group, stage 5T. Individual beds are up to $10 \mathrm{~m}$ thick; the height of the wall is about $100 \mathrm{~m}$. Southern Johannes V. Jensen Land.

in the southernmost localities around inner Frederick E. Hyde Fjord (Fig. 44). The conglomerates often form the base of fining-thinning upward cycles, considered to reflect waning deposition resulting from episodes of slumping and successive development of mass flows and turbidity currents. The conglomerate sheets can be traced over a wide area of Amundsen Land, but become less important westwards and northwards. The northernmost localities of the Amundsen Land Group, just north of the present Harder Fjord fault in Johannes V. Jensen Land, are characterised by thick units of black chert and mudstone, reflecting increasing stagnation of the trough.

The redeposited material represented by the Early Ordovician conglomerate sheets is of interest in the links that can be made with conditions in the source areas of the shelf (Surlyk \& Hurst, 1984). The dominant clast composition of the conglomerates changes upward from flat pebble carbonates to black chert, reflecting a change in source area and lithology. Also, while boulder and cobble grades dominate the lower conglomerates, pebble grades become dominant in the higher parts of the conglomerate succession. The eroded material is considered to have been transported across the outer shelf and shelf-slope break in a series of debris flows. On the shelf to the south, a correlation can be made with a period of uplift and erosion preceding deposition of the Wandel Valley Formation (see above); the sub-Wandel Valley Formation unconformity overlies and oversteps rocks from Late Proterozoic to earliest Ordovician age (Figs 15, 17A, 30; Map 1). Although much of the hiatus is believed to be due to non-deposition, there was evidently significant Early Ordovician erosion.

Eventually conglomerate and turbidite deposition faded out and the quiet, slow sedimentation of finegrained deposits was resumed. These include green and green-grey ribbon cherts, chertified mudstones and siltstones and thin-bedded silty turbidites, all referred to the Nordpasset Formation.

The youngest deposits of stage 5T include black cherts and mudstones, dark silty mudstones, siltstones and thin-bedded silty turbidites of the Harder Fjord Formation (Late Ordovician - Early Llandovery). 
These deposits herald an important event in the evolution of the trough, with the starved basin deposition of the Amundsen Land Group being brought to a close in latest Ordovician to Early Silurian times (Hurst \& Surlyk, 1982; Surlyk \& Hurst, 1984). The abrupt onset of sandstone turbidite deposition of the Peary Land Group, however, seems to have started nearly everywhere in the Late Llandovery (Higgins \& Soper, 1985; Hurst \& Surlyk, 1982).

\section{Stage 6: Early Silurian ramp and rimmed shelf, and turbidite trough}

In the early Late Llandovery, deposition of a major system of sand turbidites derived from the rising Caledonian mountain belt to the east was initiated in the trough, although the earliest pulses of deposition of distal fine-grained turbidites took place in the latest Ordovician (see stage 5T). The trough filled rapidly. By about the Llandovery-Wenlock boundary, the Navarana Fjord escarpment which had formerly marked the platform margin was drowned and the trough expanded southwards (stage 7; Figs 3-5). The loading effect of the thick sequences of turbidites accumulating in the trough caused down-flexing of the outer part of the platform. Carbonate deposition continued during this general deepening of the shelf, but variation in facies became more complex, especially in the western part of the region.

\section{S: Ramp and rimmed shelf}

The down-flexing of the outer shelf can be traced all across North Greenland, as a drowning event which occurred progressively later towards the west and covered the shelf with mudstones and turbidites of the Peary Land Group. In Washington Land this process started during the late Early Llandovery (stage 5S) but it is included here as the drowning was an integrated event which affected the entire shelf. In western North Greenland some outlying carbonate mounds survived the initial phase of drowning and continued to accrete, but only for a limited span of time. Concomitantly, the carbonate shelf margin retreated to a new, more southerly position. In this area shelf sediments of stage $6 \mathrm{~S}$ are referred to the Djævlekløften, Kap Godfred Hansen and Pentamerus Bjerge (all Washington Land Group; Figs 2, 4; Hurst, 1980a; Sønderholm \& Harland, in prep.); slope sediments are referred to the Lafayette Bugt and Cape Schuchert Formations of the Peary Land Group (Figs 2, 4; Hurst, 1980a; Hurst \& Surlyk, 1983a). In Kronprins Christian Land and Peary Land the downflexing resulted in a widespread deepening of the car- bonate platform during the early Late Llandovery and deposition of the Odins Fjord Formation (Hurst, 1984).

The Odins Fjord Formation (200-350 m) comprises in the lower part dark, massive, nodular or wavy bedded skeletal wackestone and weakly laminated lime mudstones. Burrow mottling is common, whereas algal remains are rare. The sediments reflect deposition in low energy subtidal environments (Hurst, 1984).

In southern Peary Land peritidal environments prograded northwards, represented by the Melville Land Member $(15-30 \mathrm{~m})$, which consists of grey fenestral and laminated lime mudstones (Hurst, 1984). A further rise in relative sea-level took place in late Middle to early Late Llandovery (middle Odins Fjord Formation) and sediments of low-energy subtidal environments were deposited both in northern and southern shelf areas. In the Late Llandovery, continuing relative sea-level rise in the northern platform areas immediately south of the platform margin is indicated by the Bure Iskappe Member $(30-60 \mathrm{~m})$ which comprises cherty, thin-bedded, nodular wackestones, horizontally laminated lime mudstones and rare interbeds of terrigenous mudstones (Fig. 4). Algae have not been recorded from this member. These features suggest deposition in very low energy, relatively deep-water environments below the photic zone, possibly under partly anoxic conditions (Hurst, 1984). This event is probably contemporaneous with the final drowning of the outer platform further to the west (Sønderholm \& Harland, in prep.), and records a general world-wide eustatic sea-level rise (Johnson et al., 1985).

In the southern platform areas the contemporaneous sediments of the Odins Fjord Formation are much like the lower part of this formation, but contain abundant biostromal units rich in in situ stromatoporoids and skeletal debris. The units are lenticular on a kilometre scale, suggesting sedimentation on extensive high energy shoals in the euphotic zone, with smaller intervening lower energy, subtidal areas.

In similar fashion to the peritidal environments of the Melville Land Member, these large scale shoals did not prograde further north than to an east-west line running through central Peary Land, suggesting that some preexisting shelf topography with an increase in dip at this line, prevented further progradation of the shallow marine facies (Hurst, 1984).

Sediments of the Odins Fjord Formation in the G. B. Schley Fjord region and in Kronprins Christian Land have not been investigated in detail but the environments were probably also here subtidal (Hurst, 1984).

The margin of the Peary Land shelf during this late stage is poorly known, but some information on the rim facies of the Odins Fjord Formation is yielded by boul- 


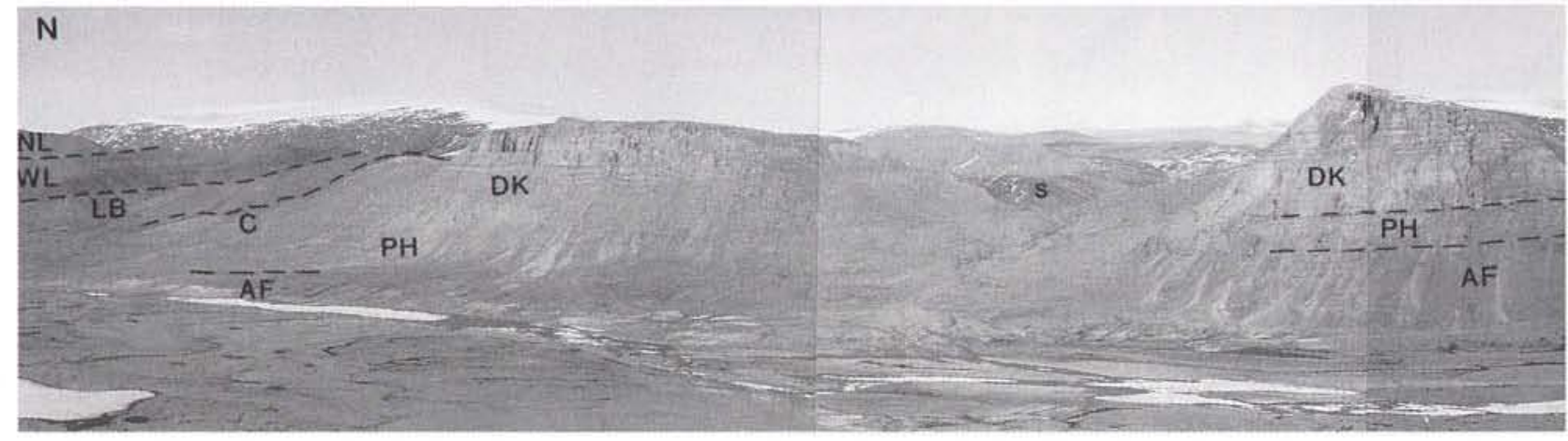

Fig. 45. Shelf-trough transition of stage 6, as developed in eastern Wulff Land. At the shelf edge pale weathering biostromal carbonates and mounds $(\mathrm{m})$ of the Djæulekløften Formation (DK) form large promontories resulting in a steep and indented shelf margin. Between and behind the shelf margin carbonates of the Djævlekløften Formation dark shales ( $\mathrm{s}$ ) occur. Further back on the shelf dark weathering carbonate mud and wackestones occur with local developments of pale weathering intrashelf mounds (im). Carbonate conglomerates (c) surrounding foreslope mounds occur in a base-of-slope setting and together with interbedded

ders contained in contemporaneous base-of-slope conglomerates of the Freja Fjord Member (Fig. 2). These show clasts up to $10 \mathrm{~m}$ in diameter of grainstones and algal-bryozoan boundstones, suggesting that the platform was rimmed by a series of high-energy shoals and incipient algal-bryozoan reefs. The platform margin in Peary Land was still developed as the steep sediment by-pass zone of the Navarana Fjord escarpment, although stratigraphic considerations indicate that the height of the escarpment was gradually reduced due to trough infill during the Early Silurian (Hurst, 1984; Surlyk \& Ineson, 1987a).

The drowning of the northern part of the shelf in western North Greenland was accompanied by a retreat of the shelf margin to a more southerly position running from south of Nares Land through central Wulff Land to central Hall Land (Figs 3, 45). As a consequence of the increased subsidence, the Petermann Halvø Forma-

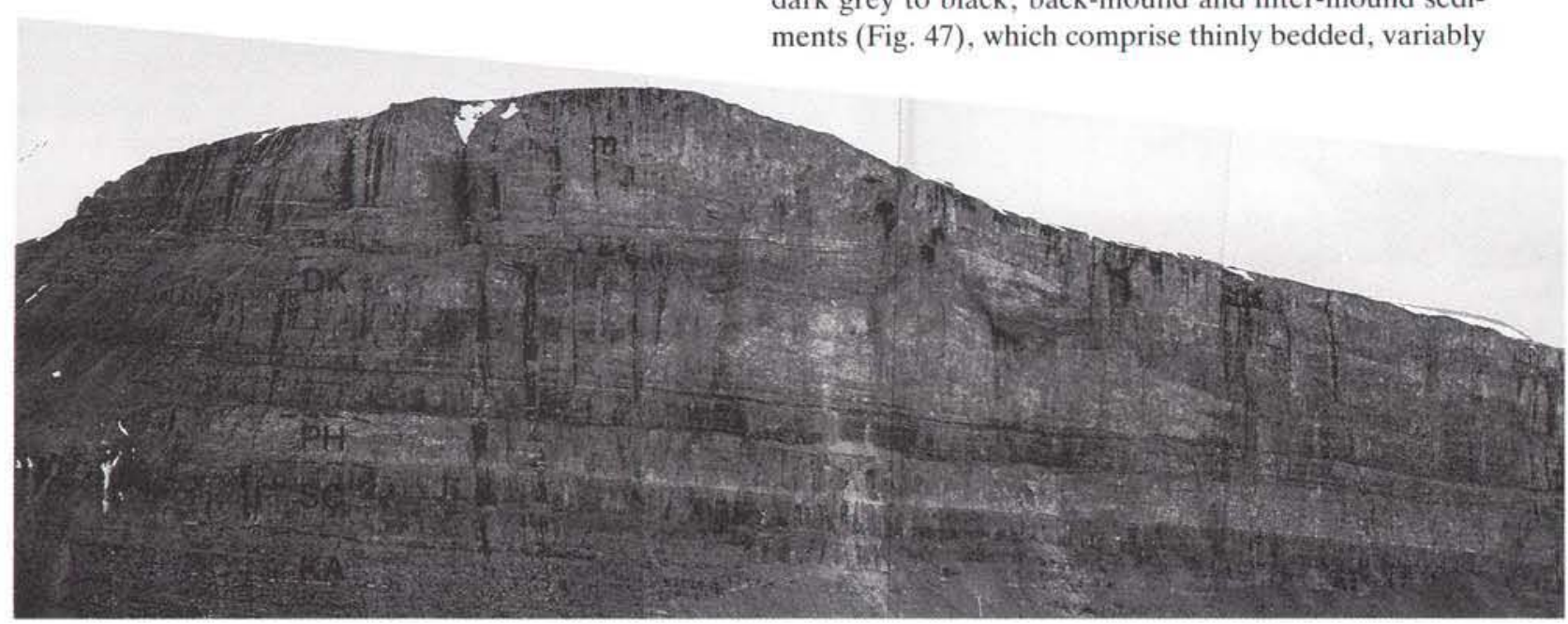

tion (stage $5 \mathrm{~S}_{1}$ ) is locally overlain by a series of mounds (basal mounds of the Djævlekløften Formation) which increase in size and numbers towards the north (Figs 38, 39). However, the mound complexes along the shelf margin did not form a complete barrier across the region and a steep indented margin developed with promontories hosting large slope mounds and re-entrants infilled with dark, cherty lime muds and shales. South of the shelf margin an essentially flat carbonate platform was maintained, probably sloping gently towards the north (Figs 2, 4, 45; Sønderholm \& Harland, 1989b; Sønderholm \& Harland, in prep.).

The Djævlekløften Formation (up to $c$. $600 \mathrm{~m}$ ) preserves a complex array of facies, with dark, often shaly or cherty lime mudstone, variably coloured mound-related flank beds including skeletal limestone and biostromes, isolated mounds and mound complexes (Fig. 46). The southern part of the platform is dominated by dark grey to black, back-mound and inter-mound sediments (Fig. 47), which comprise thinly bedded, variably 


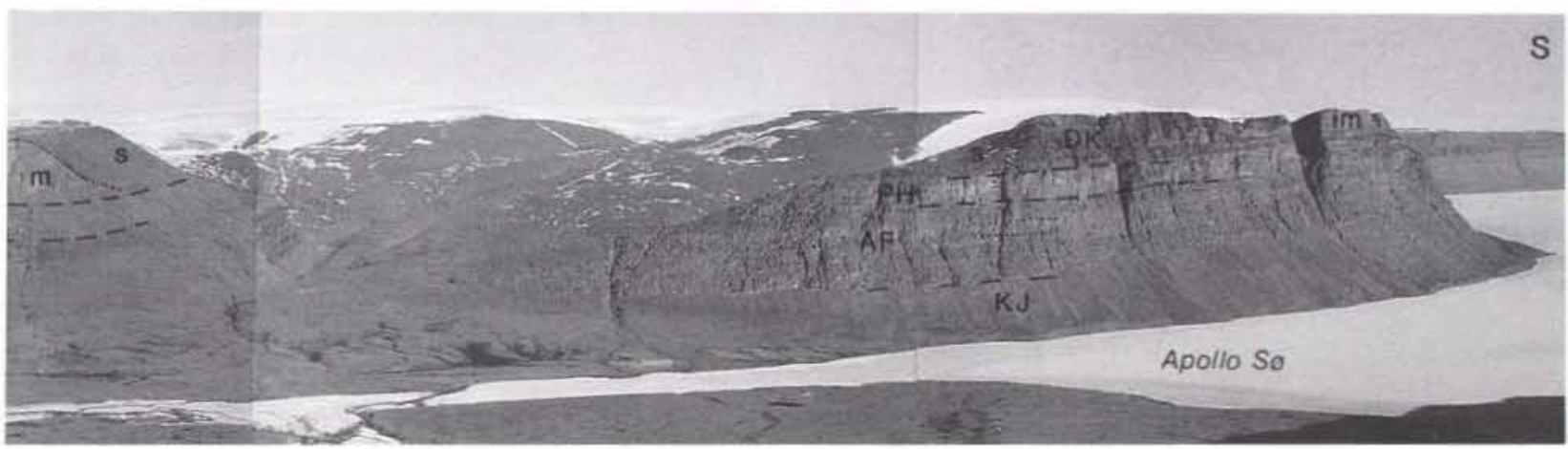

mudstones form the Lafayette Bugt Formation (LB). Trough deposits (stage $7 \mathrm{~T}$ ) are represented by dark mudstones of the Wulff Land Formation (WL) and pale turbidites of the Nyeboe Land Formation (NL). Carbonate platform deposits of stage 5S, are represented by the Kap Jackson Formation (KJ, with Cape Calhoun Formation on the top), the Aleqatsiaq Fjord Formation (AF, showing three-part member sub-division) and the Petermann Halvø Formation (PH). Height of mountain in centre about $900 \mathrm{~m}$.

mottled, skeletal lime mudstones with thin interbeds of graded bioclastic limestones, pebble conglomerates and slump sheets. Chert layers and nodules occur throughout. These sediments drape on to, or terminate against, light grey to dark grey carbonate mound sediments. The mounds are mostly small, up to $200 \mathrm{~m}$ thick, patch reefs which especially to the north along the shelf margin may interconnect to form large mound complexes (Fig. 48). In western Washington Land these large mound complexes form part of the Pentamerus Bjerge and Kap Godfred Hansen Formations, while the Kap Jefferson mound of the Adams Bjerg Formation probably is an equivalent to the intrashelf mounds of the Djavlekløften Formation (Hurst, 1980a; Sønderholm \& Harland, 1989b; Sønderholm \& Harland, in prep.).

Around the major mounds and mound complexes, sequences of generally pale weathering, very variable limestones up to $200-450 \mathrm{~m}$ thick occur. These are typically associated with the upper parts of the mounds, spreading mainly southwards, and form the top of the Djæulekløften Formation in many areas. The limestones mainly comprise interbedded dark and light stro- matoporoid and coral biostromes (Figs 45, 49). The dark beds contain in situ stromatoporoids and corals (Fig. 50), while the pale beds contain abundant reworked material. Crinoid material occurs virtually throughout, and beds up to $10 \mathrm{~m}$ thick consisting almost entirely of crinoid columnals are common. In exceptional cases, major mound complexes are flanked by up to $200 \mathrm{~m}$ thick successions almost exclusively composed of crinoid columnals.

Sedimentation patterns in Washington Land west of Bessels Fjord reflect a somewhat different evolution. In this area the carbonate platform of stage 5 developed into a homoclinal carbonate ramp during the late Early Llandovery. In the westernmost areas this event is represented by starved slope sediments of the Cape Schuchert Formation $(55-80 \mathrm{~m})$ which mainly consist of thin bedded, black, bituminous, cherty lime mudstones overlying the Aleqatsiaq Fjord Formation. Contemporaneously, fringing reefs and reef-derived sediments at the carbonate ramp margin represented by the Pentamerus Bjerge and Kap Godfred Hansen Formations and probably parts of the Adams Bjerg Formation (Hurst, $1980 \mathrm{a})$, led to the development of a scarp between the platform and the slope, resulting in a greater ramp-to-

Fig. 46. Shelf-edge mounds ( $\mathrm{m}$ ) of the Djavlekløften Formation (DK) of stage $6 \mathrm{~S}$. To the north (right), limestone conglomerates derived from the mounds interdigitate with dark basinal shales (Lafayette Bugt Formation, LB). The Djavlekløften Formation overlies shelf sediments of stage $5 \mathrm{~S}_{1}$ (Petermann Halvs Formation (PH), Store Canyon (SC) and Kap Ammen (KA) Members of the Aleqatsiaq Fjord Formation). Eastern cliffs of southern Nares Land, southern Nordenskiöld Fjord. Cliff height c. $650 \mathrm{~m}$. 


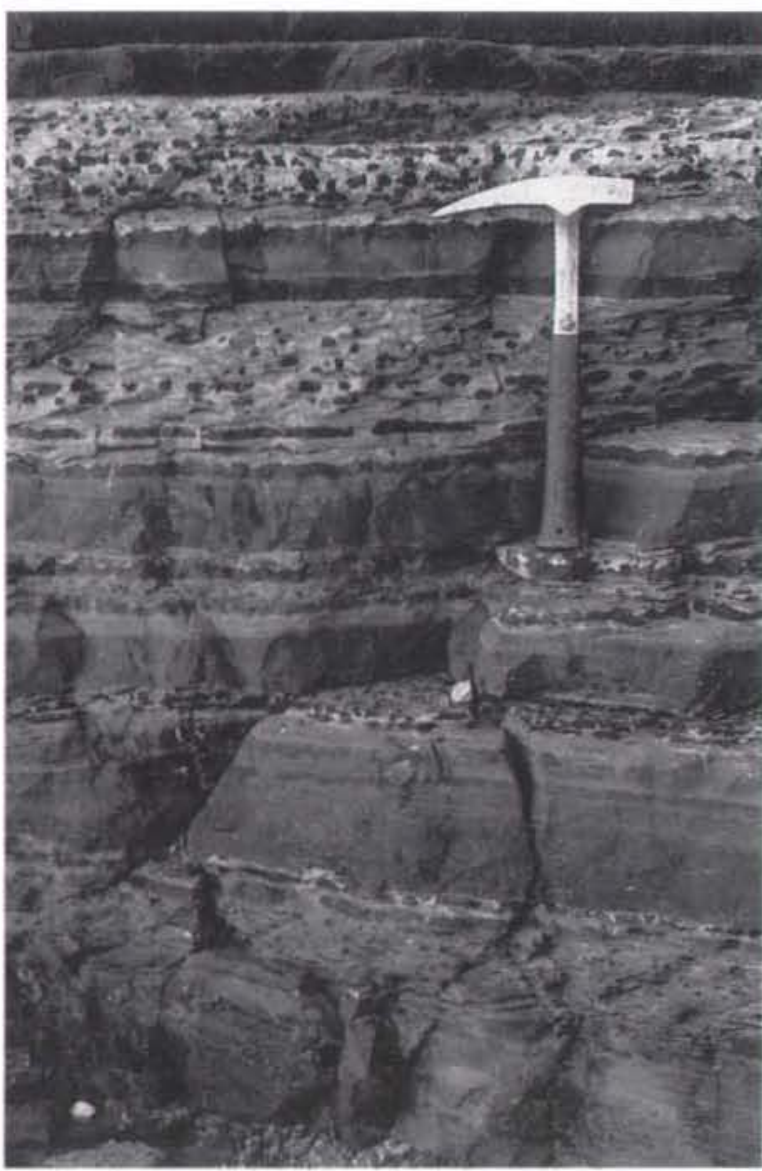

Fig. 47. Dark, finely laminated intermound lime mudstone of the Djavlekløften Formation (stage 6S) with black chert in nodules and layers. Hammer is $35 \mathrm{~cm}$ long. Central Warming Land.

slope differentiation (Figs 2, 4; Hurst, 1980a; Hurst \& Surlyk, 1983a).

As a consequence of continuing sea-level rises during the late Middle to latest Llandovery, the south-western part of Washington Land was drowned during the earliest Late Llandovery, and inundated by the black shales of the Lafayette Bugt Formation. Contemporaneously, new mounds were initiated on the slope further to the east at Kap Independence (Fig. 51), while the impressive carbonate ramp-margin reef belt continued its development (Hurst, 1980a; Hurst \& Surlyk, 1983a).

\section{T: Longitudinal turbidite trough}

The most dramatic depositional change in the deepwater trough took place in the early Late Llandovery when a major longitudinal, sand-rich, turbidite system was developed following the late Early Cambrian - earliest Silurian starved basin phase (Figs 2, 3, 5, stage $6 \mathrm{~T})$. An early phase of fine-grained dilute turbidity current deposition was initiated close to the OrdovicianSilurian boundary in the eastern part of the trough. Significant turbidite deposition, however, started abruptly in Late Llandovery time and a sand-rich elongate submarine fan system rapidly developed (Hurst \& Surlyk, 1982; Surlyk, 1982; Surlyk \& Hurst, 1984). Turbidite deposition continued throughout the Silurian, and the resulting succession is placed in the Peary Land Group. The formations of the Peary Land Group, dominated by sandstone turbidites, mudstones or conglomerates (Hurst \& Surlyk, 1982; Larsen \& Escher, 1985, 1987; Surlyk \& Ineson 1987a, b), are interpreted here as stages $6 \mathrm{~T}-7 \mathrm{~T}$ in the evolution of the basin.

The initiation of stage $6 \mathrm{~T}$ is represented by the very thick sequence of sandstone turbidites of the Merqujô Formation ( $>500-2800 \mathrm{~m}$ ), which appears to be largely Late Llandovery in age (Higgins \& Soper, 1985; Hurst \& Surlyk, 1982; Larsen \& Escher, 1985). These turbidites are widely distributed in North Greenland between Frederick E. Hyde Fjord in the east and northern Nyeboe Land in the west (Figs 9, 52). In some areas there is a gradual increase in grain size at the top of the starved slope sequence, passing into the first sandstone turbidites, while in other areas the contact with the thick sandstone turbidites interdigitates with the starved slope facies (Higgins \& Soper, 1985; Hurst \& Surlyk, 1982; Surlyk et al., in prep.). Turbidite deposition commenced abruptly in central Johannes V. Jensen Land in the Llandovery with the incoming of extremely thick (up to $30 \mathrm{~m}$ ) sandstone turbidite beds, distinguished as the Sydgletscher Formation (Fig. 53) (Hurst \& Surlyk, 1982).

The main part of the Merqujôq Formation represents deposition in the outer-fan and trough floor environment in a highly elongate east-west submarine fan system. Palaeocurrents are uniform towards the westsouth-west, parallel to the Navarana Fjord escarpment which formed the margin of the carbonate platform. Turbidite deposition took place right up to the escarpment, and the steep profile of the scarp slope may have been maintained by erosion by longitudinal turbidity currents. The top part of the formation is characterised by complex channelling interpreted as representing a braided mid-fan environment (Fig. 54). The largest observed channels have widths of several hundred metres and depths of about $50 \mathrm{~m}$. Turbidite sedimentation was punctuated by several episodes of carbonate conglomerate deposition; beds range from 0.5 to $50 \mathrm{~m}$ in thickness and, in type, from well-sorted pebble beds to totally disorganised boulder beds with individual clasts often reaching a diameter of several metres (Figs 55, 56). In 
Fig. 48. Dark intermound sediments and mounds $(\mathrm{m})$ of the Djavlekløften Formation (DK) belonging to stage $6 \mathrm{~S}$. Sediments of stage $5 \mathrm{~S}_{1}$ are represented by the Newman Bugt (NB), Kap Ammen (KA) and Store Canyon (SC) Members of the Aleqatsiaq Fjord Formation (AF), and the overlying Petermann Halvo Formation (PH). Looking east in Store Canyon, southern Nyeboe Land. Height of mountain about $550 \mathrm{~m}$.

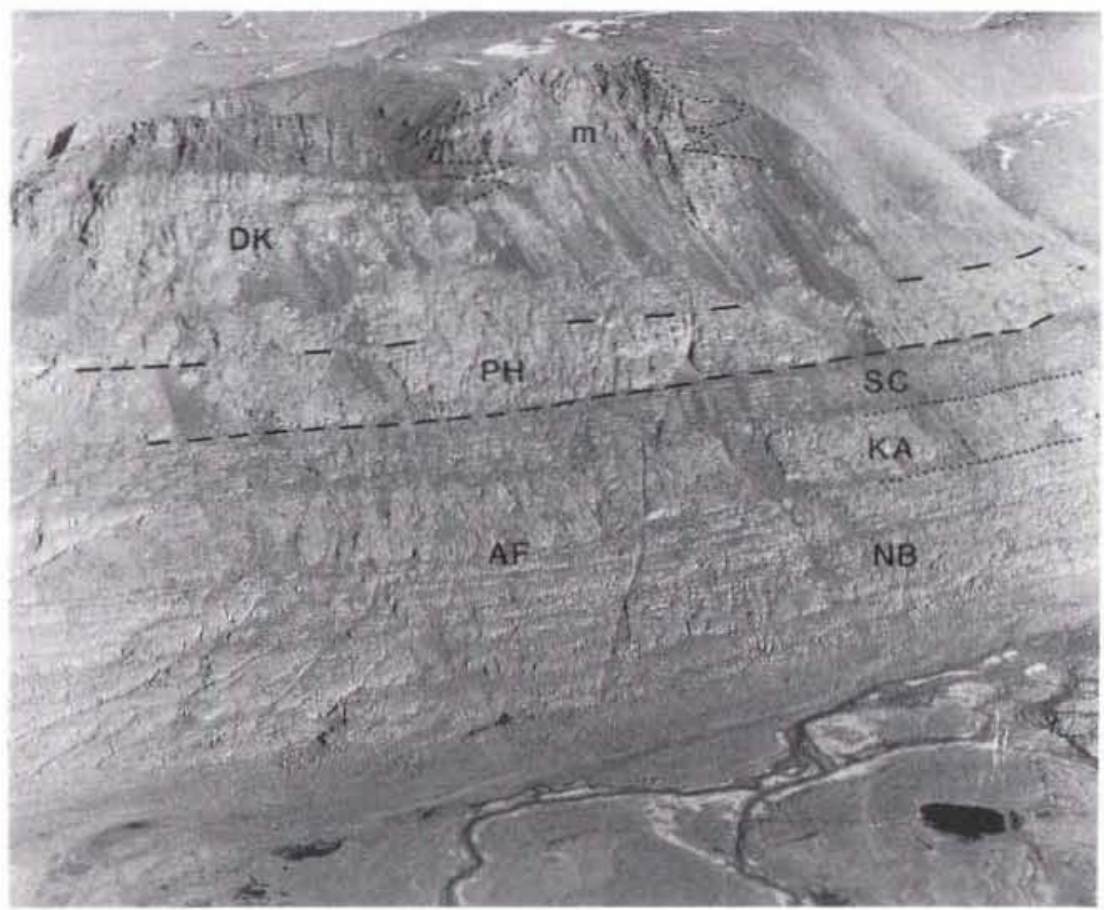

contrast to the longitudinally derived turbidites, the conglomerates were derived from the southern platform area and from the platform margin escarpment, as reflected in the concave erosional surface which truncates the top of the scarp at Navarana Fjord (Surlyk \& Ineson, 1987a, b).

\section{Stage 7: Final drowning of the platform}

The last phase in the evolution of the Silurian carbonate ramp and rimmed shelf was a consequence of continued shelf foundering and associated sea-level rise (Figs 3, 5, stage 7). The trough expanded southwards as a result of eustatic sea-level rise, the loading effect of the thick turbidite sequence to the north and downflexing caused by encroaching Caledonian nappe sheets in
Fig. 49. Biostromal deposits of stage $6 S$ (Djavlekløften Formation, DK) overlain by mound-complexes (Hauge Bjerge Formation, HB, stage 7S) and siliciclastic sediments of the Peary Land Group (PL, stage $7 \mathrm{~T})$. Kap Tyson, western Hall Land. Height of cliff is $740 \mathrm{~m}$.

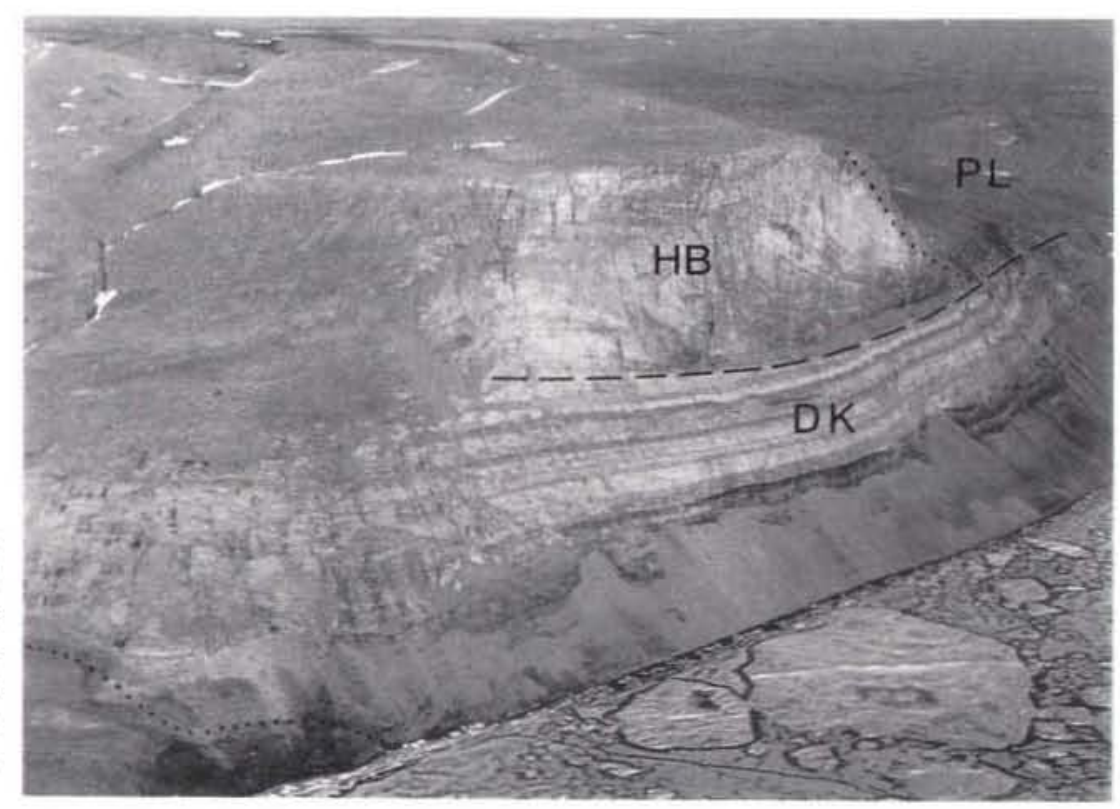




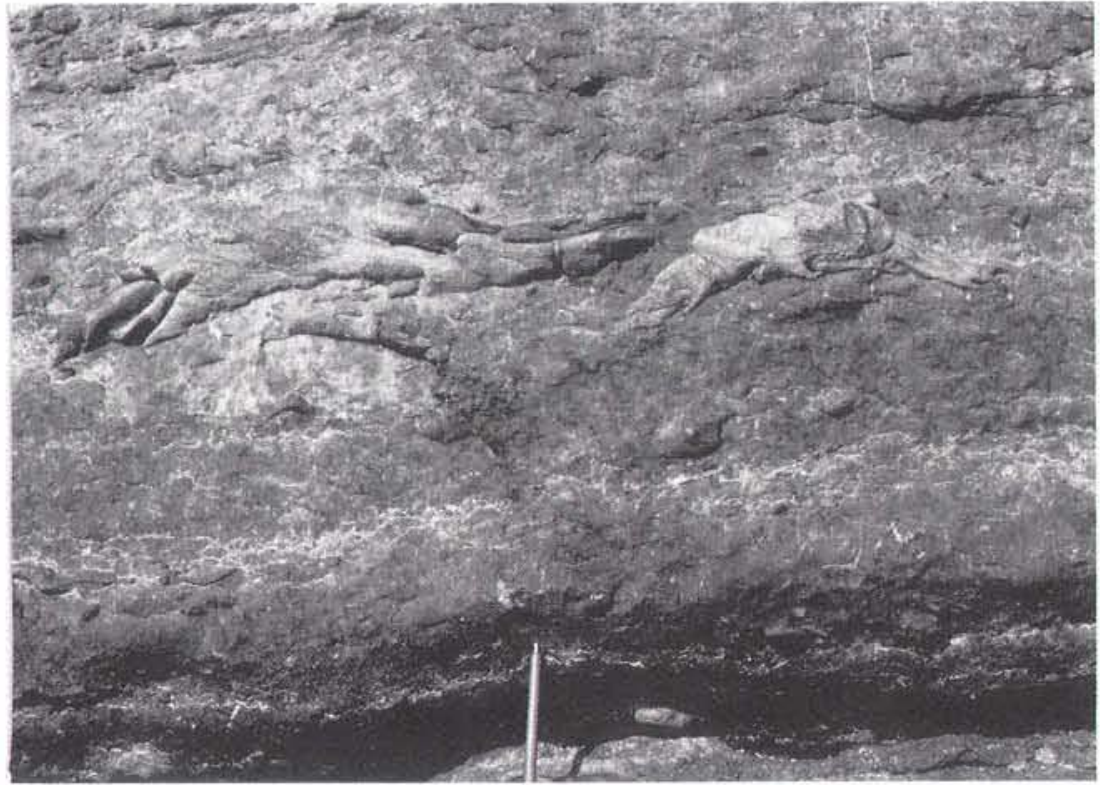

Fig. 50. Biostromal limestone of the Djavlekløften Formation (stage 6S) with abundant in situ stromatoporoids and corals. Pencil $15 \mathrm{~cm}$ long. Offley Island.

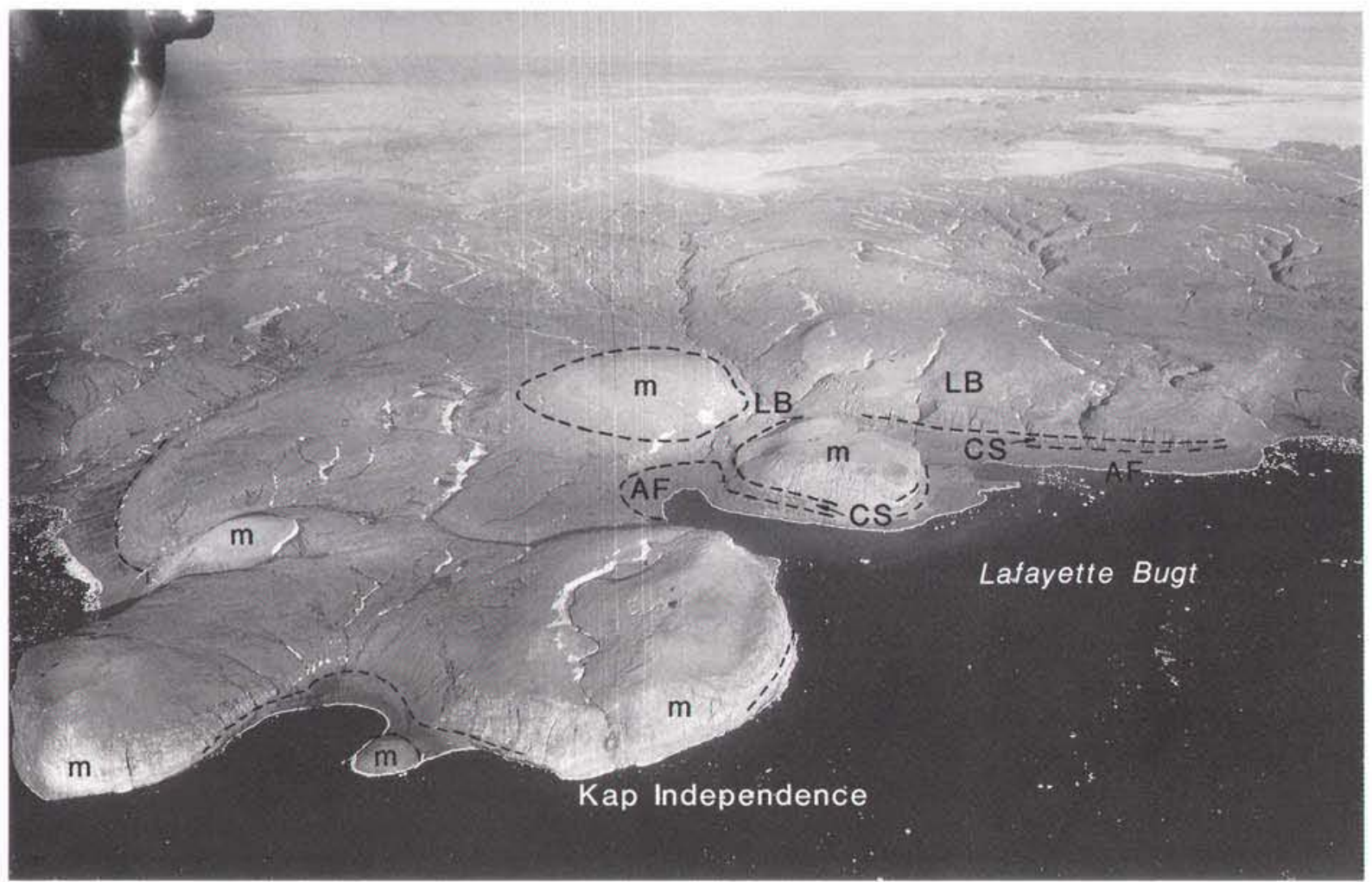

Fig. 51. Carbonate mounds (m) of the Kap Independence Member (Pentamerus Bjerge Formation) embedded in slope deposits of the Cape Schuchert (CS) and Lafayette Bugt (LB) Formations (stage 6S). AF: Aleqatsiaq Fjord Formation. Westernmost Washington Land. Aerial photograph 545 K1-S $\emptyset$ no. 2259. Copyright Kort- og Matrikelstyrelsen, Denmark; reproduced with permission A.87/200. 
Fig. 52. Sandstone turbidites of the Merqujồq Formation (ME, stage $6 \mathrm{~T})$. overlain by a thin mudstone unit, the Thors Fjord Member of the Wulff Land Formation (TFM) and sandstone turbidites of the Lauge Koch Land Formation ( $L$, stage $7 \mathrm{~T}$ ). Cross-cutting black bands are late Cretaceous dykes. West side inner J. P. Koch Fjord, cliffs $900 \mathrm{~m}$ high.

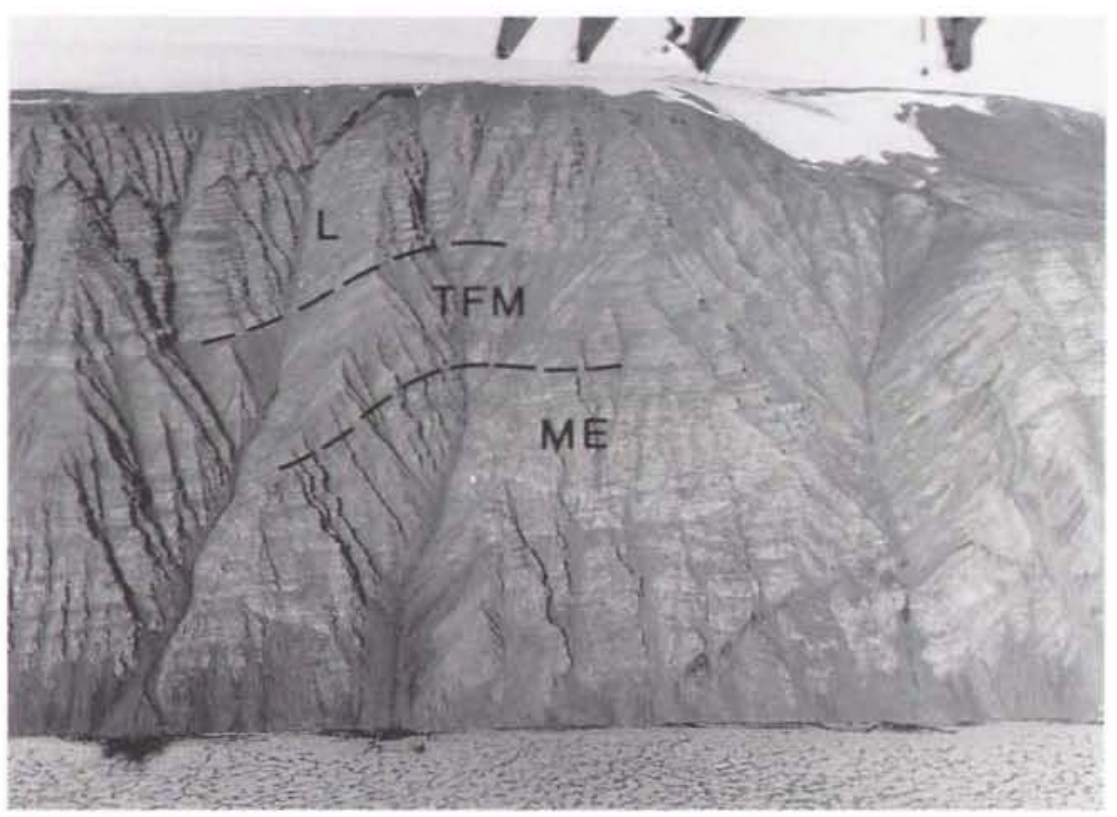

the eastern areas. Eventually the shelf was drowned completely during the latest Llandovery and carbonate sedimentation was only locally maintained around major mound complexes. The shelf was inundated by hemipelagic mudstones and siltstone turbidites of the Thors Fjord Member (Wulff Land Formation), Profilfjeldet Member (Lauge Koch Land Formation), and Lafayette Bugt Formation (Figs 2-5).

\section{S: Late Llandovery - Early Ludlow reef belt}

During the final phase of drowning of the platform. carbonate sedimentation was only locally maintained, leading to the formation of isolated mounds. These sediments are referred to the Samuelsen Høj Formation between Kronprins Christian Land and Peary Land, the Hauge Bjerge Formation in the area between western Wulff Land and eastern Washington Land, and to the Pentamerus Bjerge, Kap Godfred Hansen, Kap Morton and Kap Maynard Formations in Washington Land (Hurst, 1980a, 1984; Sønderholm et al., 1987; Sonderholm \& Harland, in prep.; Figs 2, 4). Carbonates of this late stage are not represented between western Peary Land and western Wulff Land, probably due to Recent erosion.

Fig. 53. Structureless mediumgrained sandstone turbidite of the Sydgletscher Formation, about $40 \mathrm{~m}$ thick marking the initiation of the Peary Land Group. Base of stage $6 \mathrm{~T}$. Johannes V. Jensen Land. The white band in the middle of the bed is a calcite-filled fracture.

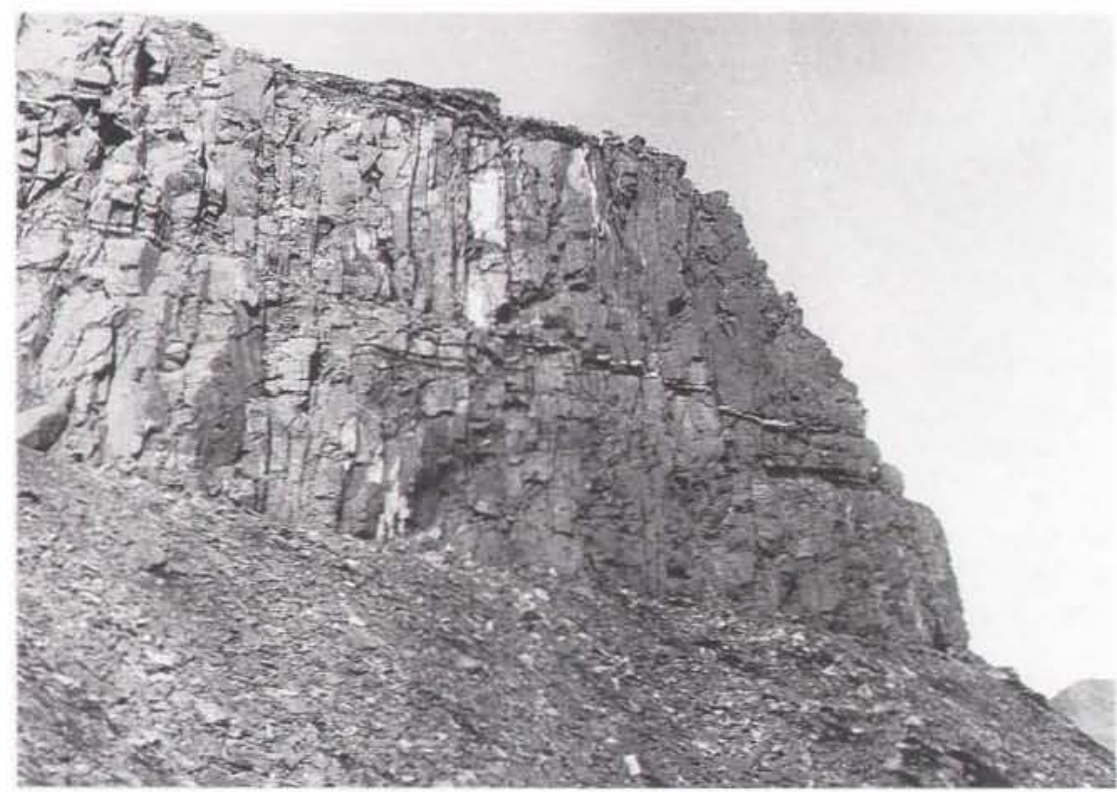




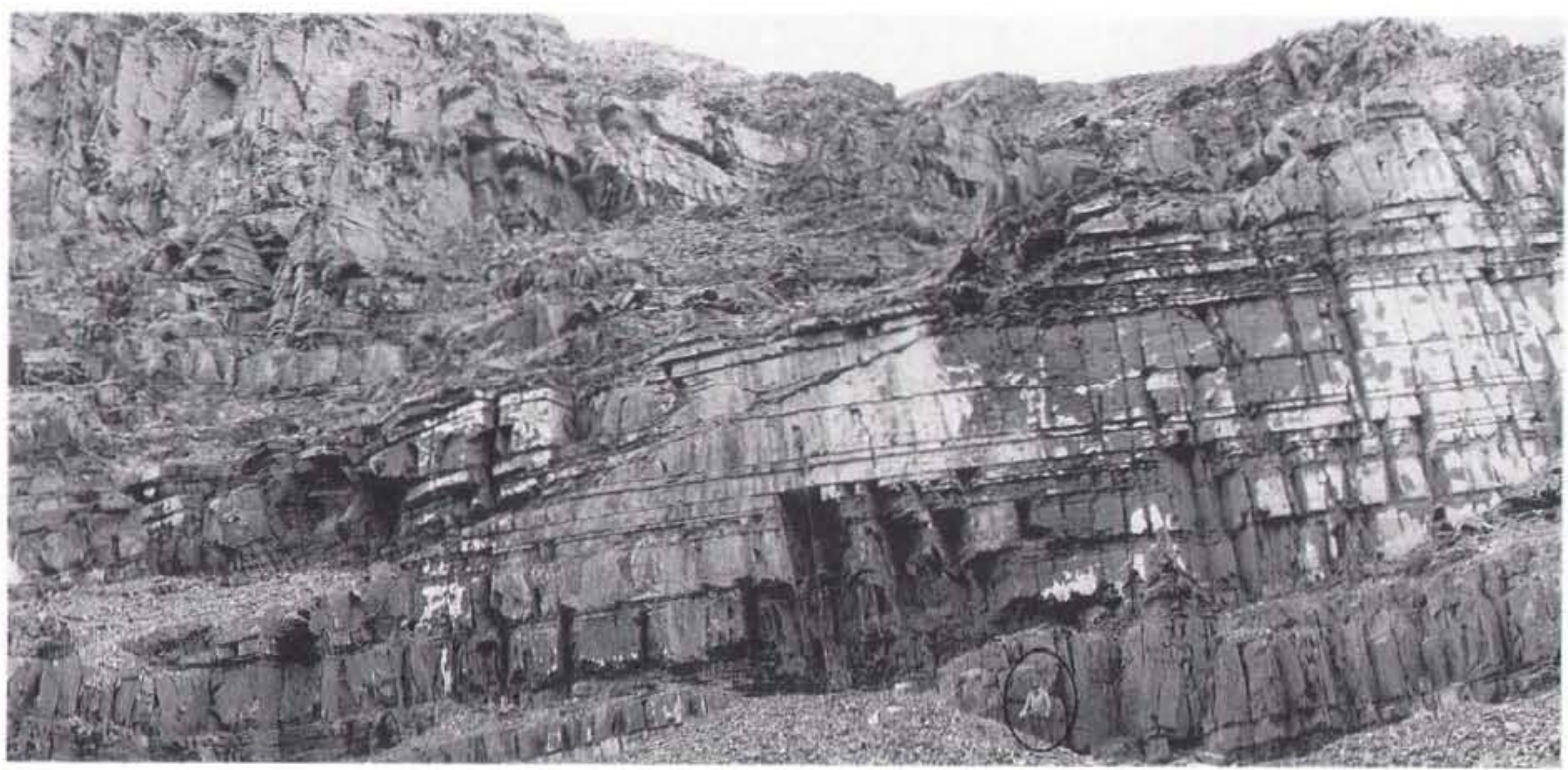

Fig. 54. Turbidite filled mid-fan channels in the top part of the Merqujôq Formation (stage 6T), Thor Fjord. Person encircled for scale.

The approximately $300 \mathrm{~m}$ high pinnacle reefs of the Samuelsen Høj Formation (Fig. 57) occur on top of the Odins Fjord Formation where they form a $50 \mathrm{~km}$ long east-west linear belt in eastern Peary Land. Mound complexes are also widespread in Valdemar Glückstadt Land and in Kronprins Christian Land (Figs 1, 4, 5) where they are larger than the mounds in Peary Land. In Kronprins Christian Land mounds appear to occur stratigraphically lower (Late Llandovery, C5) in the succession than in Peary Land (Late Llandovery, C6). since there is lateral interdigitation of the lower part of the mound complexes with the level-bedded sediments of the Odins Fjord Formation (stage 6S). Mound formation probably terminated during the Late Llandovery (C6); sparse graptolite evidence suggests that this termination occurred slightly earlier in the east than in the west (Hurst, 1984; Hurst \& Surlyk, 1982; Peel et al., 1981).

In western North Greenland mound complex or associated flank sediments form sequences approximately 200-1000 m thick (Dawes, 1987; Hurst, 1980a; Sønderholm et al., 1987; Sønderholm \& Harland, in prep.). Carbonate sedimentation was only maintained around the major mounds of the previous phase of deposition (Figs 58, 59), and it was a period of partial destruction of the mounds and mass transport by debris flows (Fig. 60). These sediments form a linear belt extending from northern Washington Land, through central Hall Land, Nyeboe Land and Warning Land to western Wulff Land which indicates the position of the former shelf edge (Hurst, 1980b; Sønderholm et al., 1987; Sønderholm \& Harland, 1989b; see Figs 1, 5). Due to presentday erosion it is not known how long carbonate deposition persisted. Hurst (1980a) and Dawes \& Peel (1984) considered that it extended at least into the Early Ludlow, but thin beds of resedimented carbonates within the Chester Bjerg Formation are of Pridoli age.

\section{T: Trough expansion}

The complex foundering of the shelf described above was associated with a southwards expansion of the trough during the Late Llandovery (Hurst \& Surlyk, 1982; Hurst et al., 1983; Larsen \& Escher, 1985; Surlyk, 1982; Surlyk \& Hurst, 1984; Sønderholm et al., 1987). The foundering of more than $30000 \mathrm{~km}^{2}$ of carbonate shelf was probably caused by the combined effects of eustatic sea-level rise, loading of the eastern shelf by Caledonian nappes, loading of the trough by several kilometres of mainly Upper Llandovery turbidites and associated downflexing of the outer shelf, and by the influx over the platform of terrigenous muds from the Caledonian mountains. The northern shelf margin was inundated by clastic sediments in the Late Llandovery. whereas the southern part first started to receive terrigenous clastics at the Llandovery-Wenlock boundary, indicating that shelf foundering was in part accomplished by flexuring. In western North Greenland the inundation of the outer platform was probably initiated in the early Late Llandovery, while it commenced 


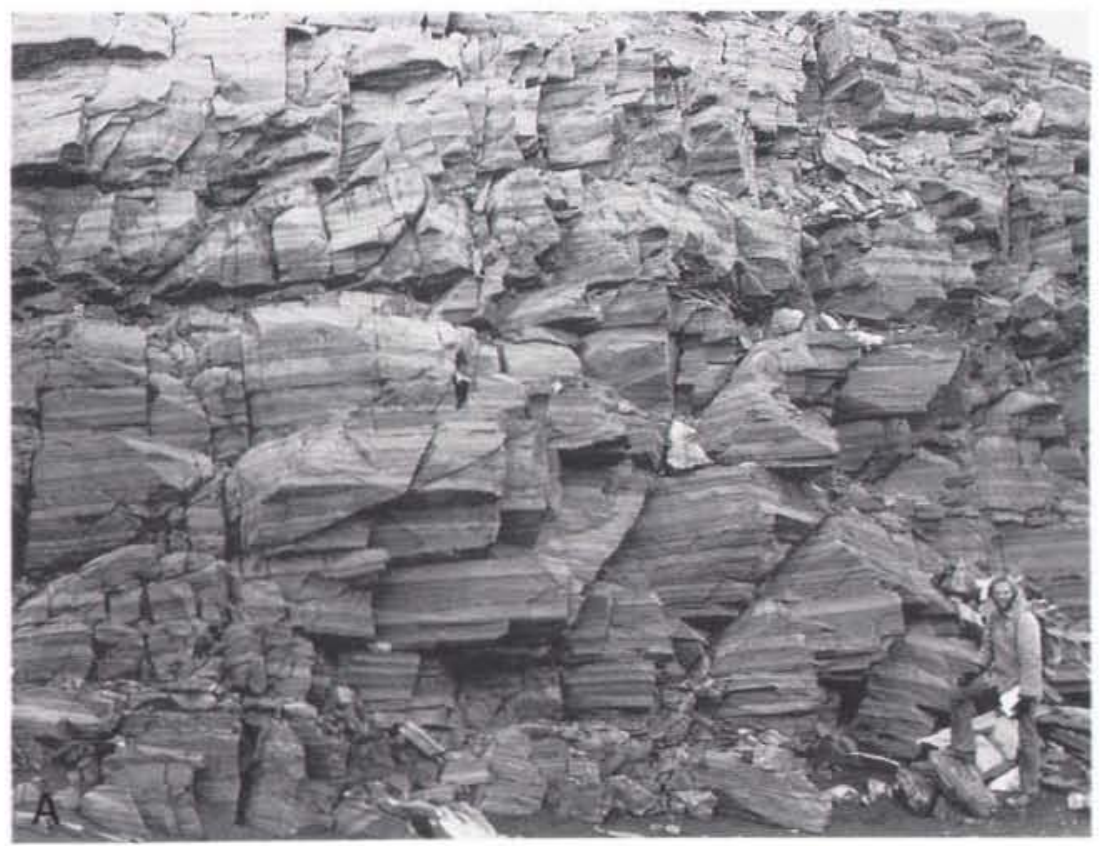

Fig. 55. Thick sequence of muddy carbonate turbidites (A) overlying carbonate boulder conglomerates of the Citronens Fjord Member shown in B (note hammer for scale). Merqujốq Formation (stage 6T), Citronen Fjord, Peary Land.

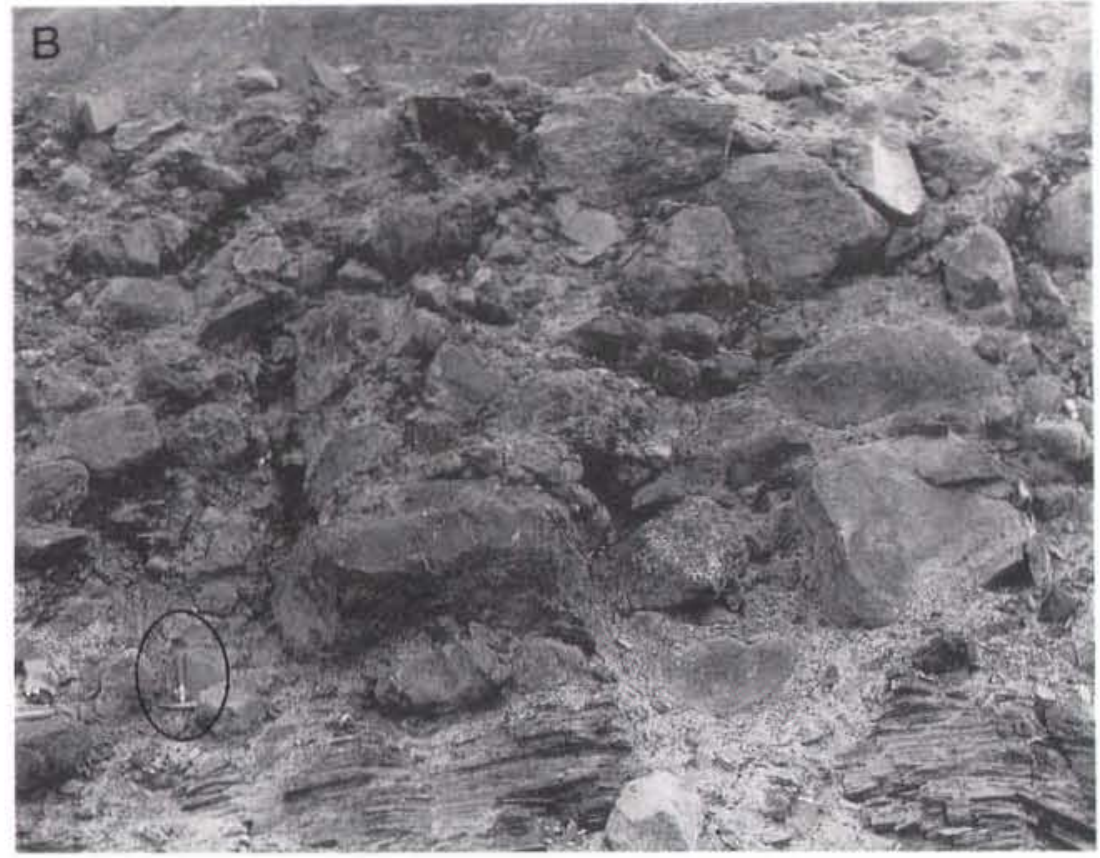

somewhat later in the Late Llandovery (C4) in central North Greenland. The extensive submergence resulted in deposition of uniform black mudstones on top of the foundered shelf carbonates and the succession of up to about $100 \mathrm{~m}$ of mudstones makes up the Thors Fjord Member of the Wulff Land Formation (Hurst \& Surlyk, 1982; Larsen \& Escher, 1985; 1987). The depositional regime can be characterised as a slope and rise system passing northward into the deep-water trough.
Following the late Llandovery - Wenlock phase of trough expansion and submarine fan starvation caused by foundering of the carbonate platform, the turbidite depositional systems rapidly built up again as an extensive, westwards prograding submarine fan system.

The turbidite deposits of this phase are mainly placed in the Lauge Koch Land Formation (Fig. 52; Hurst \& Surlyk, 1982; Larsen \& Escher, 1985, 1987; Surlyk \& Hurst, 1984). Easternmost localities in eastern Peary 


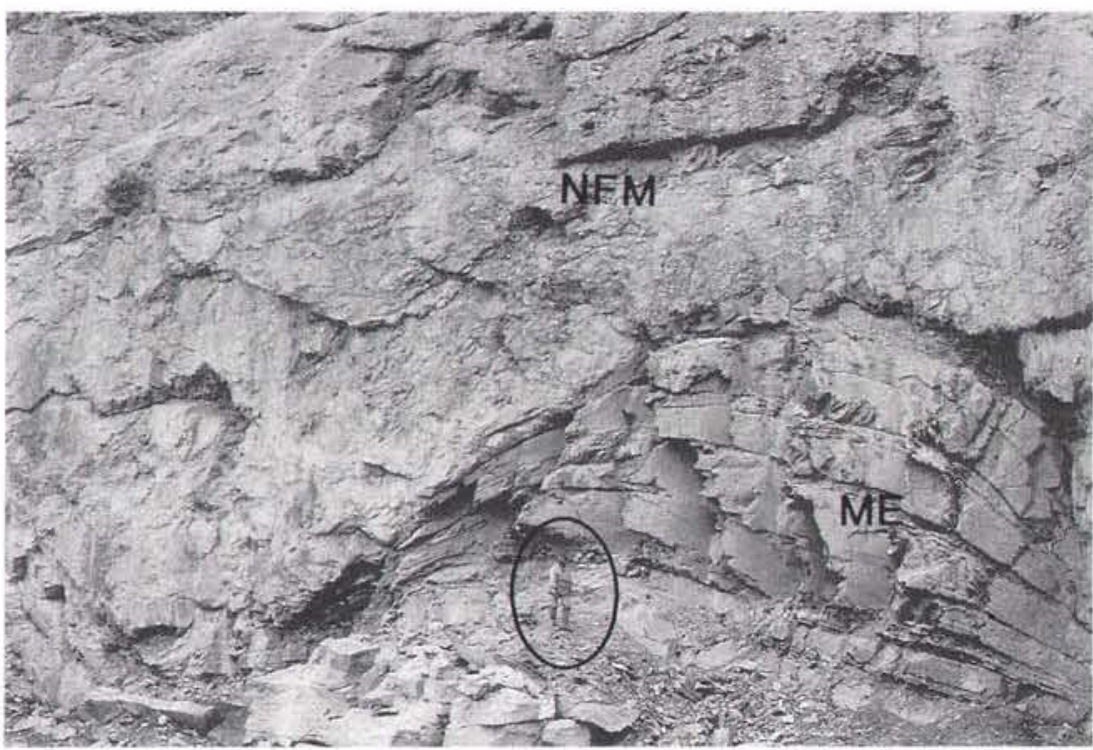

Fig. 56. Carbonate boulder conglomerate of the Navarana Fjord Member (NFM) showing giant-scale loading into sandstone turbidites of the Merqujôq Formation (ME, stage 6T). West coast of Navarana Fjord. Note person for scale.

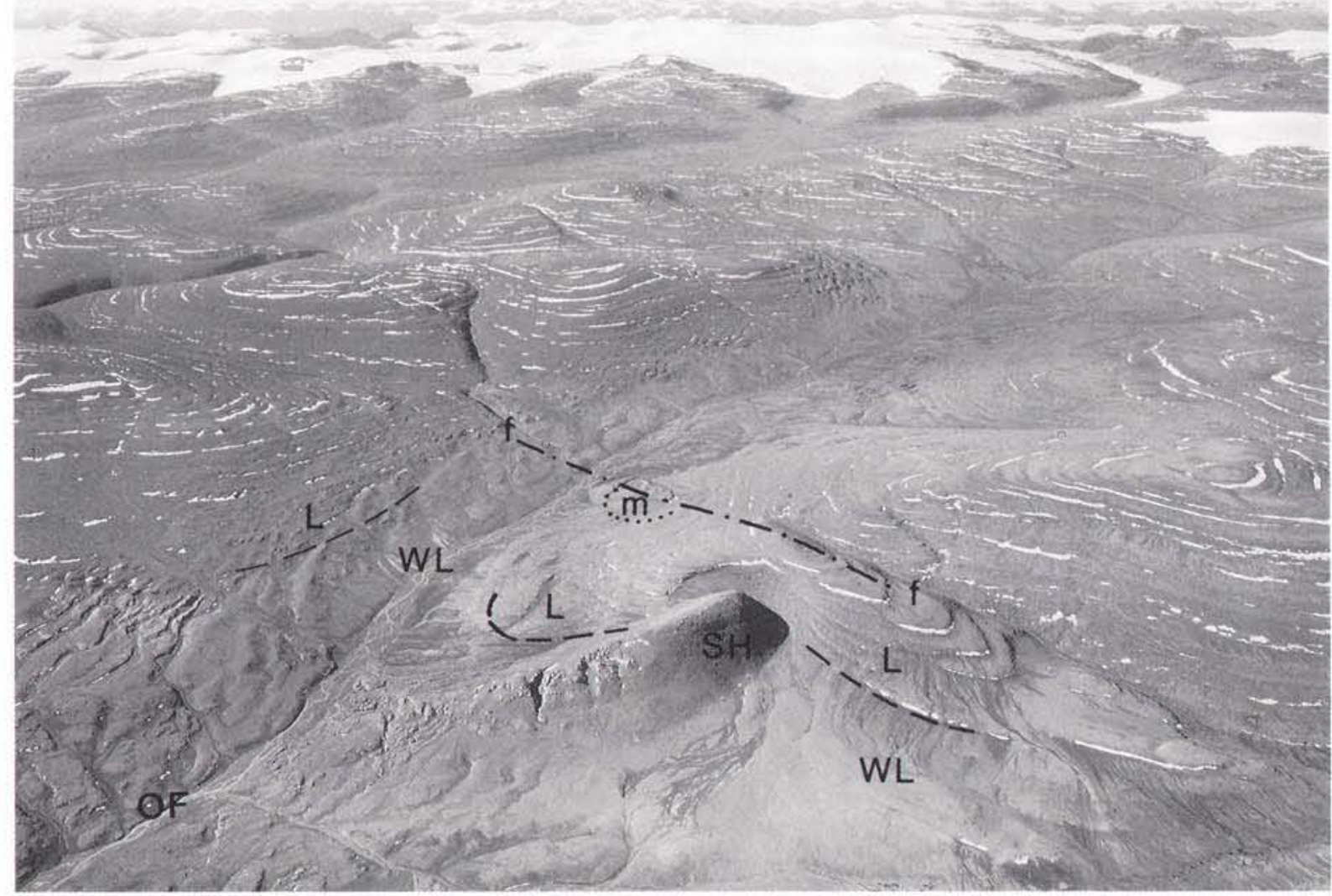

Fig. 57. Type locality of the Samuelsen Høj Formation (SH, stage 7S) in central Peary Land showing the carbonate mound forming Samuelsen $\mathrm{H} ø \mathrm{j}$ and an associated smaller mound $(\mathrm{m})$ which are rooted in Silurian shelf carbonates of the Odins Fjord Formation (OF). Siliciclastic sediments of the Peary Land Group (WL, Wulff Land Formation; L, Lauge Koch Land Formation; stage $7 \mathrm{~T}$ ) envelope the carbonates, with the turbidites of the latter formation forming characteristic terraced hills to the north. Samuelsen Høj is about $2 \mathrm{~km}$ long. Aerial photograph $548 \mathrm{C}-\mathrm{N}$, no. 4280A. Copyright Kort- og Matrikelstyrelsen, Denmark; reproduced with permission A.87/200. 


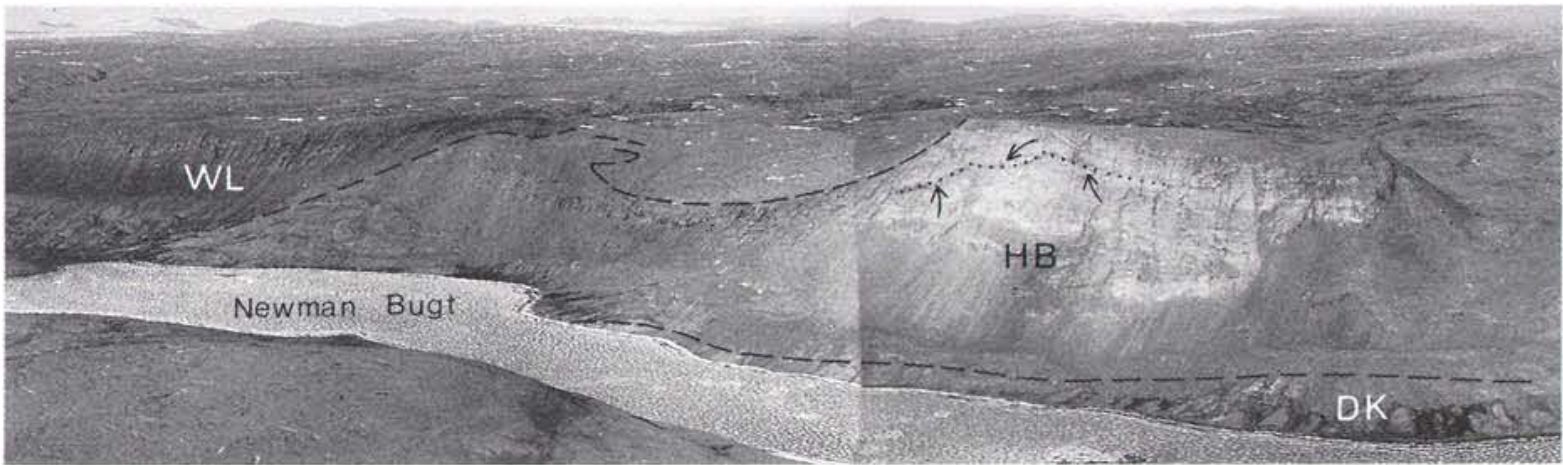

Fig. 58. Shelf edge mounds of stage 7S (HB, Hauge Bjerge Formation) on top of biostromal platform carbonates of the Djævlekløften Formation (DK; stage 6S), surrounded by shales of the Wulff Land Formation (WL) of the Peary Land Group (stage 7T). Arrows indicate possible slump scars. Western Nyeboe Land; cliffs are $550 \mathrm{~m}$ high.

Land are characterised by thick, upward-fining cycles about $50-100 \mathrm{~m}$ thick composed of thick, locally pebbly, structureless sandstones passing upwards into dark, laminated mudstones (Fig. 61). The cycles can be traced laterally for at least $5 \mathrm{~km}$. They are interpreted as representing a system of stacked, wide inner fan valleys where the upper muddy part reflects channel abandonment and passive filling. Farther westwards the inner fan valleys give way to a system of complex channels characteristic of a braided mid-fan environment. From western Peary Land and westwards to Hall Land, only outer fan, fan fringe and basin plain environments are represented (Fig. 62). West of Victoria Fjord, the sandstone/mudstone ratio, sand grain size and turbidite bed thickness decrease in a downcurrent direction.

The entire depositional setting is interpreted as an elongate submarine fan imperceptibly passing into a basin plain (Hurst \& Surlyk, 1982; Surlyk \& Hurst,
1984). Pulses in turbidite deposition alternated with periods of fan starvation resulting in alternations of turbidite sandstone and mudstone packages and in changes in the southern extent of the main turbidite body. These variations probably mainly reflect changes in sea-level, with low levels resulting in increased influx of sandy turbidity currents and high levels resulting in fan starvation and mud deposition.

During the middle Wenlock a major phase of conglomeratic deposition was initiated at the eastern, proximal end of the basin (Hurst \& Surlyk, 1982; Larsen \& Escher, 1985, 1987; Surlyk \& Hurst, 1984). The conglomeratic depositional system prograded westwards and reached northern Nyeboe Land in the early Ludlow. The conglomeratic units form the Nordkronen Formation. At the type locality south of Frederick E. Hyde Fjord the formation is incomplete, and only $100 \mathrm{~m}$ are preserved; farther west a $600-700 \mathrm{~m}$ succession oc-

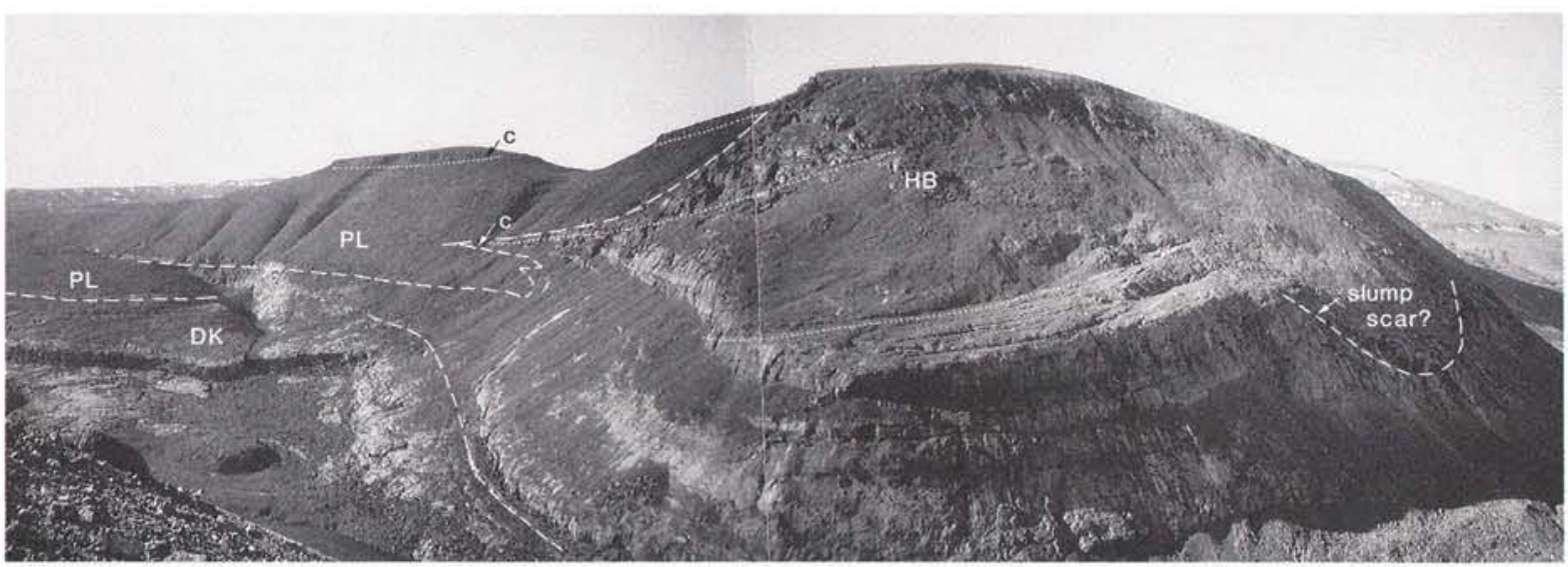

Fig. 59. Shelf edge mound of the Hauge Bjerge Formation (HB; stage 7S) on the eastern side of Hall Land overlying biostromal carbonates of the Djævlekløften Formation (DK). The mound is $c .500 \mathrm{~m}$ high and the steeply dipping beds indicate a syn-depositional relief of c. $300 \mathrm{~m}$. Note the possible slump scar on the northern, basin-ward side of the mound. The mound is surrounded by carbonate conglomerates (c) and shales of the Peary Land Group (PL; stage 7T). 


\section{A}
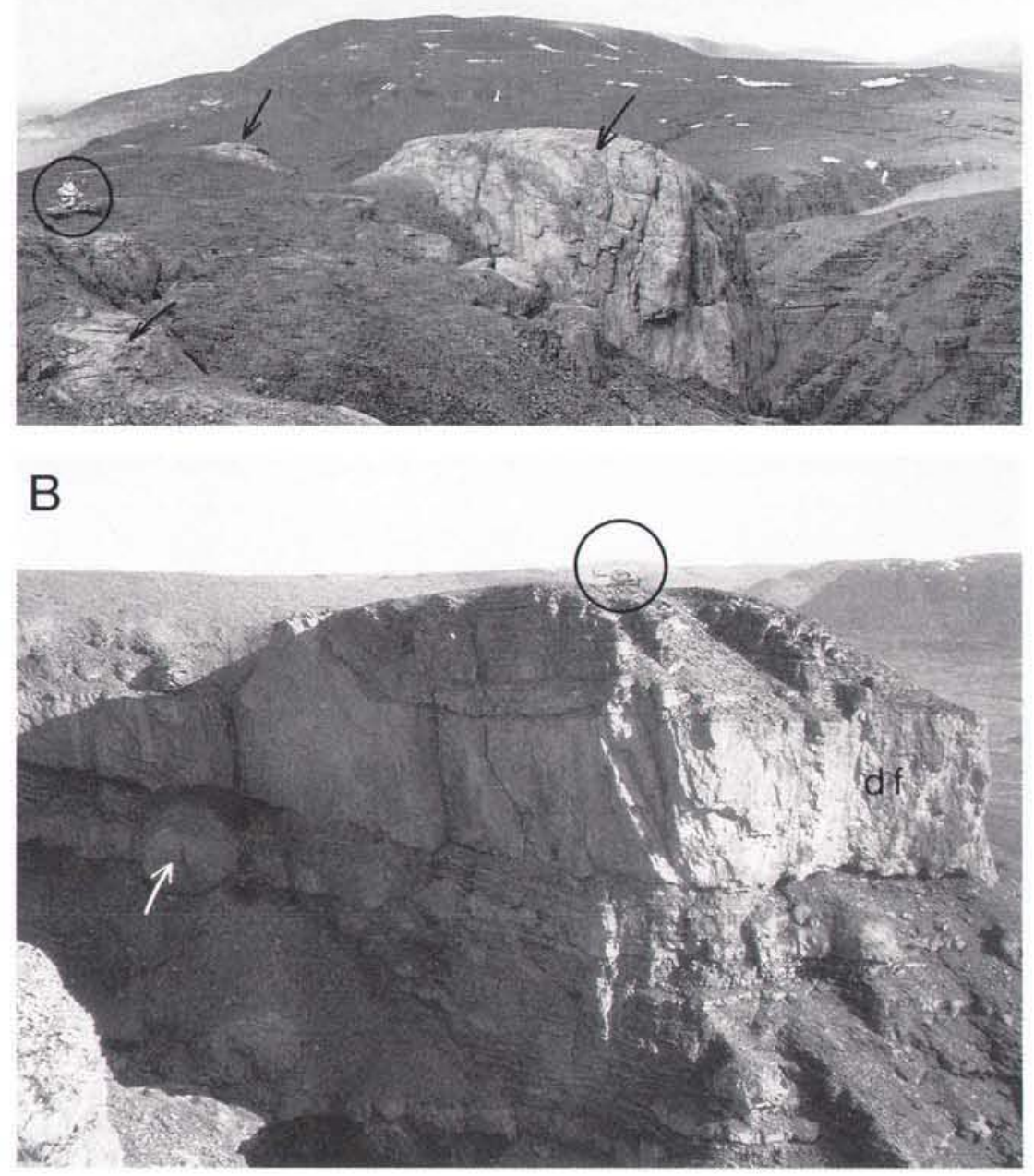

Fig. 60. Huge olistoliths (arrowed) and debris flows (df) derived from the large mound complexes of the Hauge Bjerge Formation (stage $7 \mathrm{~S}$ ) embedded in black shales of the Peary Land Group (stage 7T). Encircled helicopter for scale. A, western Hall Land; B, western Nyeboe Land. curs on Stephenson $\varnothing, 281 \mathrm{~m}$ on Hendrik $\varnothing$, and in northern Nyeboe Land a feather edge of the unit measures $32 \mathrm{~m}$.

The conglomerates differ markedly from all of the earlier deep-water conglomerates described above. The latter are all derived from the upper slope and carbonate shelf to the south; they are mainly chaotic, disorganised types with lime mud matrix, poor clast sorting, and a variety of clast lithologies. In contrast, the conglomerates of the Nordkronen Formation are more organised and are interbedded with sandstone turbidites. They occur in relatively thin, sheet-like beds, with a sandstone matrix identical to the sandy turbidites. The clasts are well sorted and rounded, pebble-sized, green, black and grey chert (Fig. 63). The chert conglomerates were deposited from high density turbidity currents travelling westwards along the trough axis from a source area in the rising Caledonian mountains (Fig. 64) (Surlyk \& Hurst, 1984).

The generally well-rounded and sorted appearance of the chert pebbles indicates that the parent rock was lithified at the time of erosion and that considerable transport and sorting had taken place in the coastal zone before redeposition by density currents. Some chert pebbles have yielded radiolarian remains suggestive of an Ordovician age, and the chert pebbles were probably derived from uplifted, thick cherty sequences of mainly Ordovician age (Vølvedal and Amundsen Land Groups 
Fig. 61. A. Stacked thinning-upwards and fining-upwards inner fan valley succession of the Lauge Koch Land Formation (stage 7T). B. Detail of the base of the lower thinningupwards sequence shown in A. Bed above stippled level is c. $1 \mathrm{~m}$ thick. Eastern Peary Land.
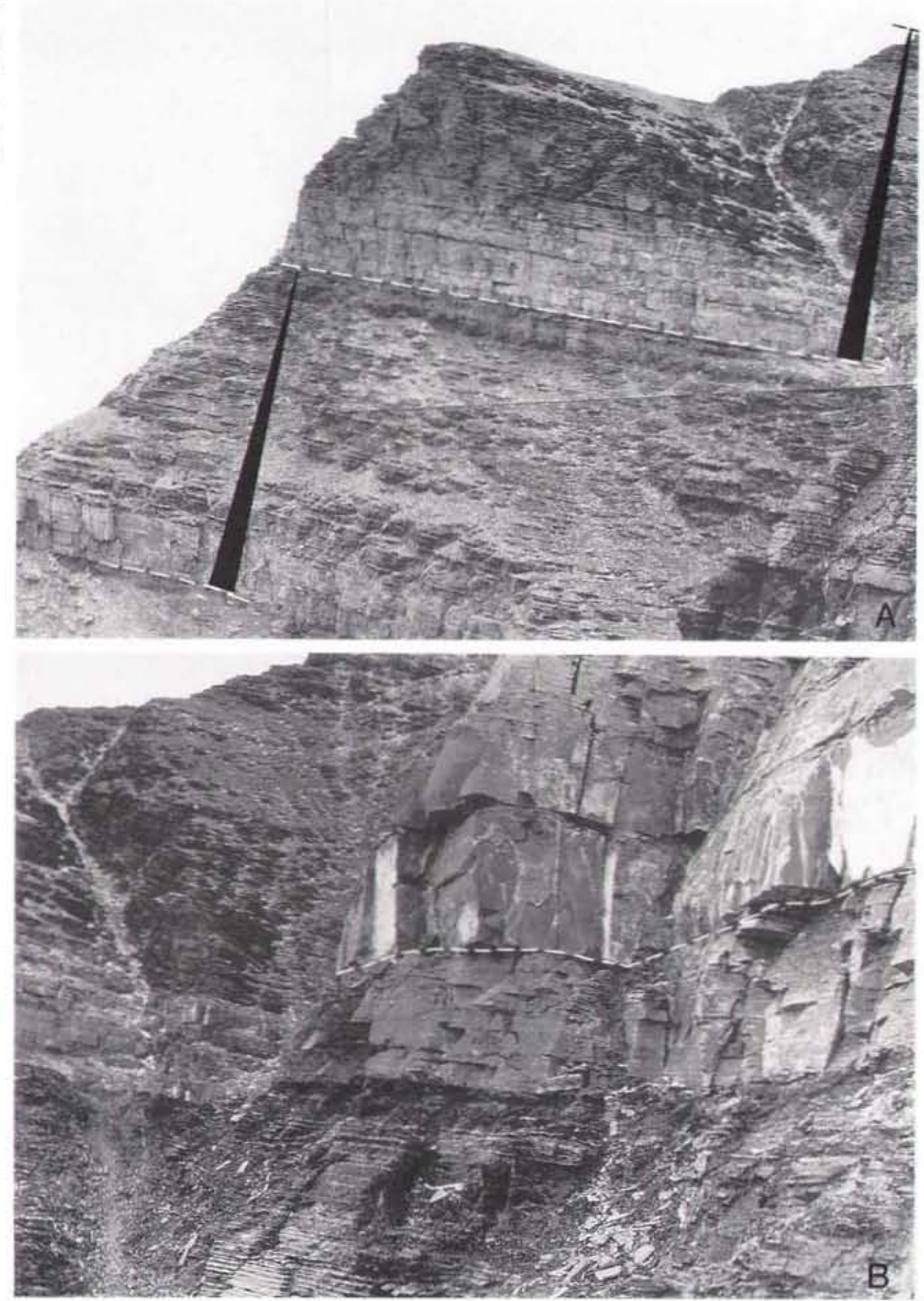

and correlatives); no other known units contain sufficient volumes of cherts.

The last phase of the trough fill is only preserved in the western part of North Greenland, west of Freuchen Land. It is represented by the Nyeboe Land Formation and the Chester Bjerg Formation (Hurst \& Surlyk, 1982; Larsen \& Escher, 1985, 1987). This part of the sequence totals about $1000 \mathrm{~m}$ in thickness and is of latest Silurian age, possibly reaching into the earliest Devonian.

In the transition zone of the Nyeboe Land Formation and the Chester Bjerg Formation, packages of fine sandstone turbidites alternate with packages of silty mudstones, often with starved ripples. This facies association reflects a fan fringe depositional environment characteristic of the transition between outer fan and basin plain deposits. The bulk of the Chester Bjerg Formation comprises laminated light green weathering mudstones or siltstones, deposited from muddy contour currents, very dilute turbidity currents, or nepheloid layers in a distal basin plain. 


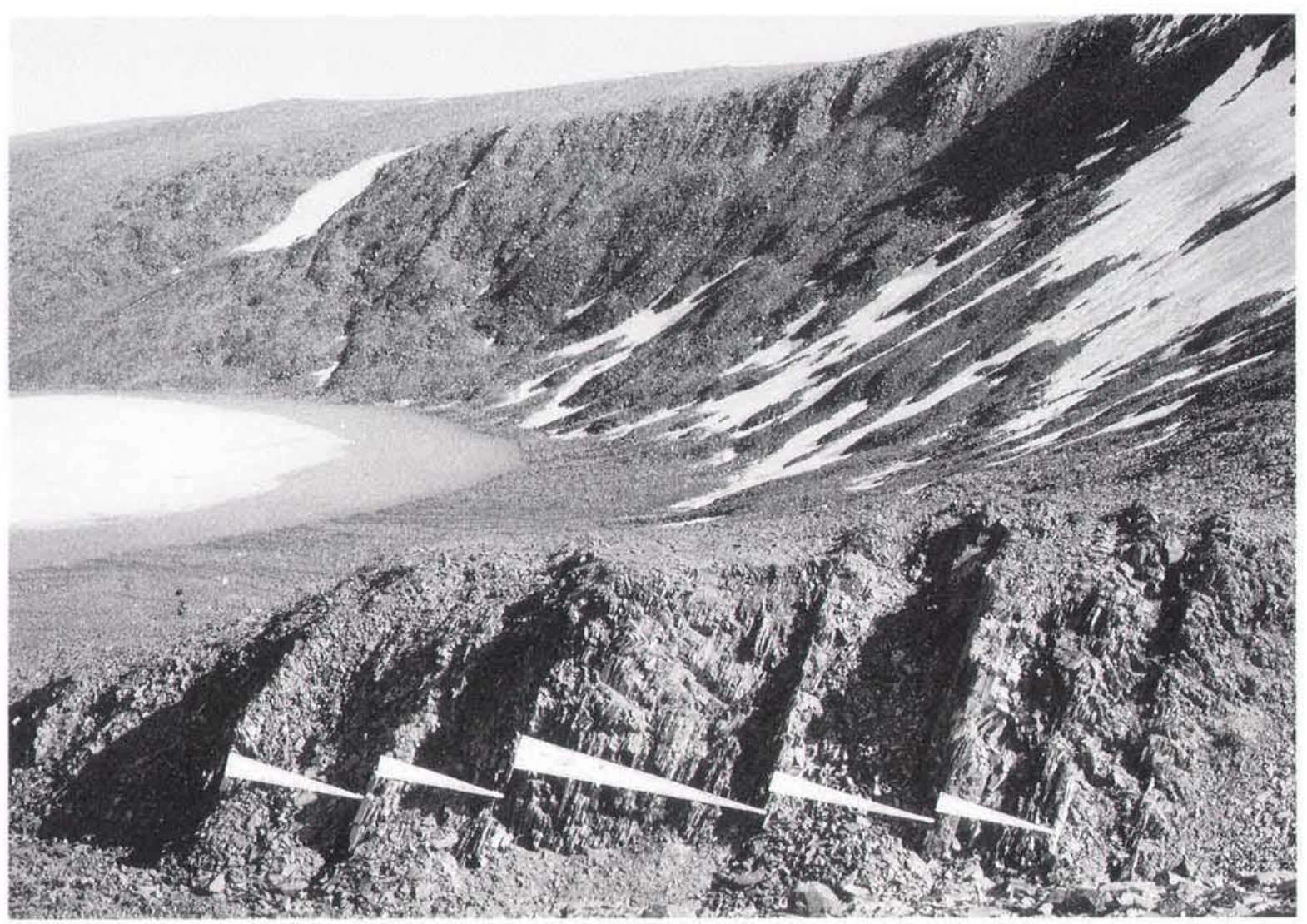

Fig. 62. Overturned sequence of stacked $20-40 \mathrm{~m}$ thick thinning-upwards cycles in the distal fan fringe of the Lauge Koch Land Formation, Peary Land Group (stage 7T), northern Nyeboe Land.

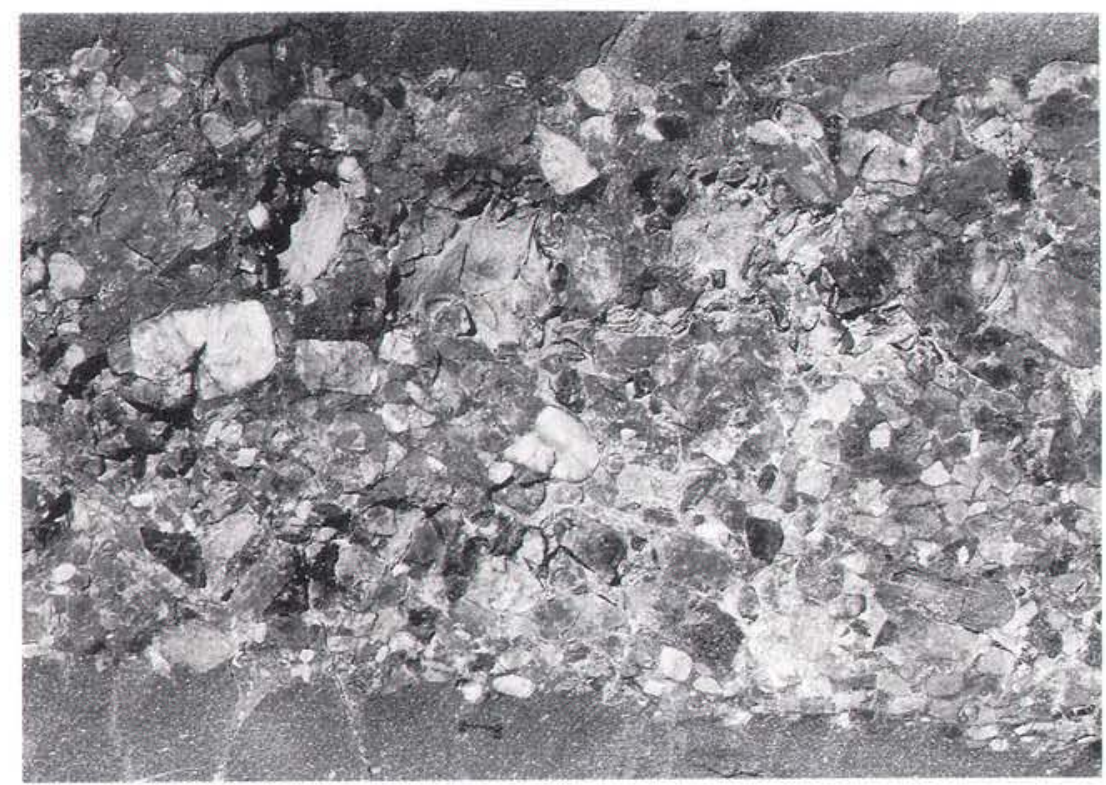

Fig. 63. Chert pebble conglomerate bed $(20 \mathrm{~cm}$ thick) showing inverse grading. Hendrik $\emptyset$ Member (stage $7 \mathrm{~T})$, Hendrik $\varnothing$. 
Fig. 64. Large scale flute casts on the sole of vertical chert pebble conglomerate of the Hendrik $\emptyset$ Member (stage $7 \mathrm{~T}$ ). Current towards the top of picture. Hammer for scale. Stephenson $\emptyset$.

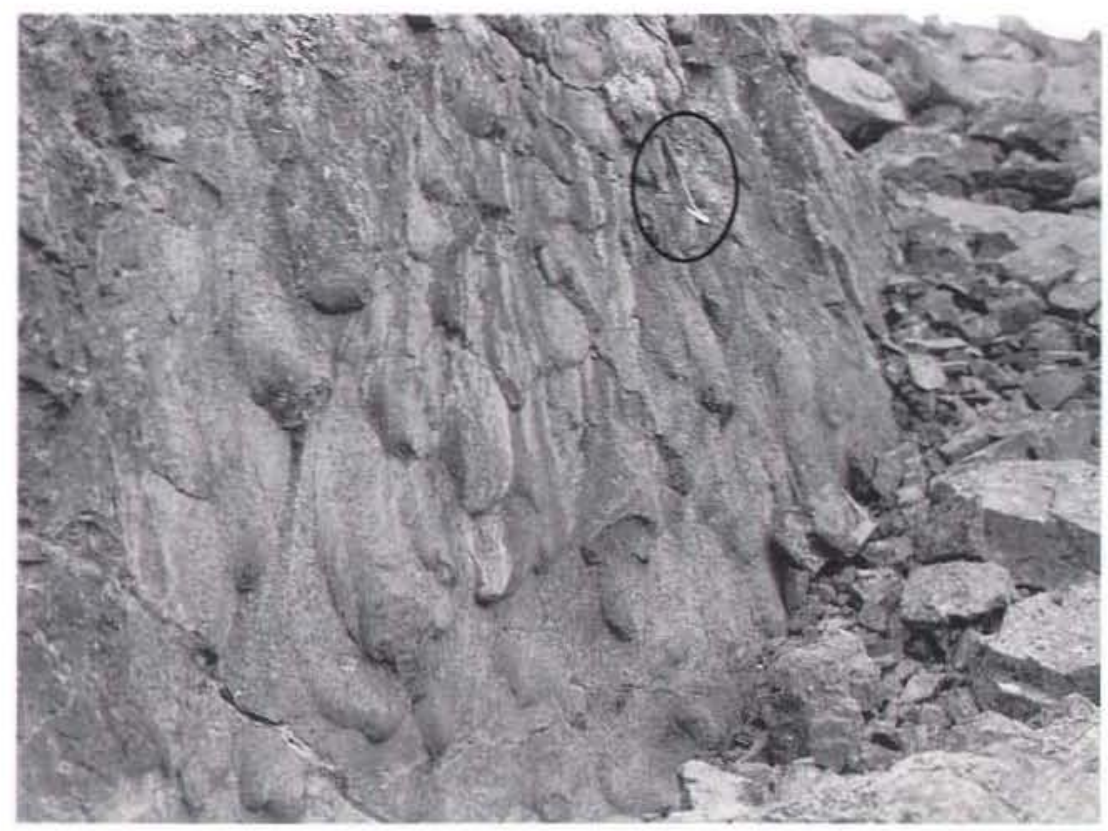

\section{Caledonian and Ellesmerian events in North Greenland}

The Early Palaeozoic Franklinian Basin in North Greenland seems to have formed by rifting. It may thus be of fully ensialic nature, or an aulacogen, or it may represent continental break-up and formation of a narrow ocean (Surlyk \& Hurst, 1984). The nature of the crust beneath the basin is not well known, but it is probably of continental or transitional type in most of its preserved, southern part. Thus, the basin reflects the evolution of a normal, passive continental margin. However, a number of events during basin evolution can be related to the progressive closure of the Iapetus Ocean and the formation of the East Greenland Caledonides (Surlyk \& Hurst, 1984).

The earliest and most conjectural event was the uplift of the eastern shelf areas in Cambrian and Early Ordovician time, resulting in a marked hiatus which decreases progressively towards the west away from the Iapetus margin (Figs 2, 4). This phase was followed by the incoming in the Early Silurian of enormous amounts of sandy turbidites forming the submarine fan system of the Peary Land Group. The sedimentation rate increased dramatically and the bulk of the turbidite sequence was deposited during a short time interval in the Late Llandovery. The turbidites had their source area in the rising Caledonian mountain belt to the east; their initiation gives the most precise time record of Iapetus Ocean closure and orogenic uplift in the present northern North Atlantic region. In the Late Llandovery huge areas of carbonate platform foundered, probably due to the combined effect of downflexing of the outer platform caused by loading of the trough with several kilometres of sediments derived from the rising Caledonides, and loading by westwards advancing Caledonian nappes and thrust sheets (Fig. 42).

The next phase was characterised by the incoming in mid-Wenlock time of westward-prograding chert-pebble conglomerates, perhaps originating from upthrust Ordovician chert sequences exposed to erosion in Caledonian thrust sheets.

The Franklinian Basin in North Greenland thus records the evolution of a carbonate-dominated, passive east-west trending continental margin, exposed to the influence of the closure of the Iapetus Ocean and the building of the Caledonian mountains to the east. The Franklinian Basin in North Greenland finally closed in Devonian - Early Carboniferous times, resulting in strong deformation of the northern part of the Franklinian trough sequence during the Ellesmerian Orogeny. 


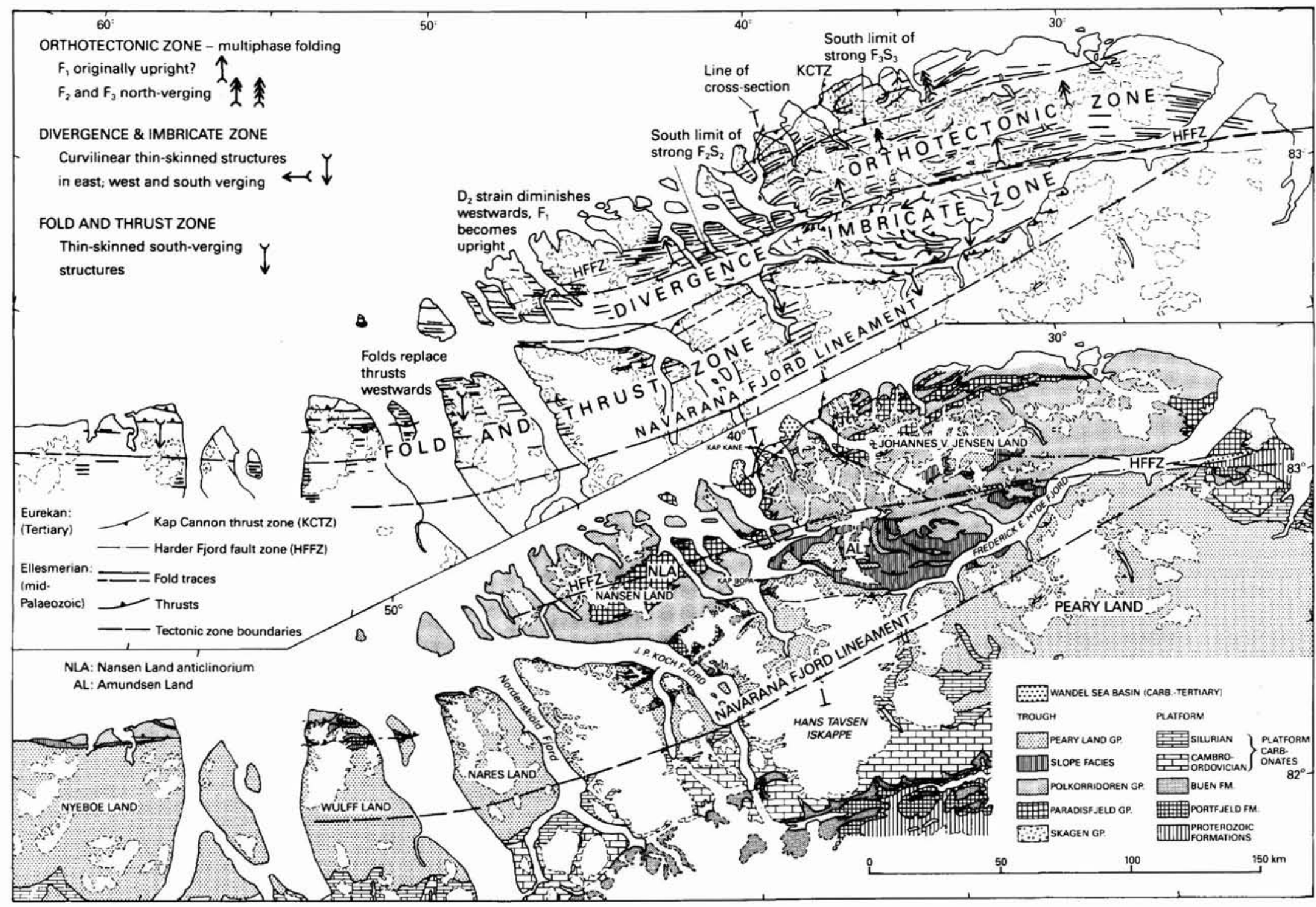

Fig. 65. Upper structural map shows trends of main folds and thrusts in the North Greenland fold belt and the division into three tectonic zones. The lower geological map shows the distribution of main units of the trough and shelf succession. Modified after Soper \& Higgins (1987). 


\section{KAP KANE}

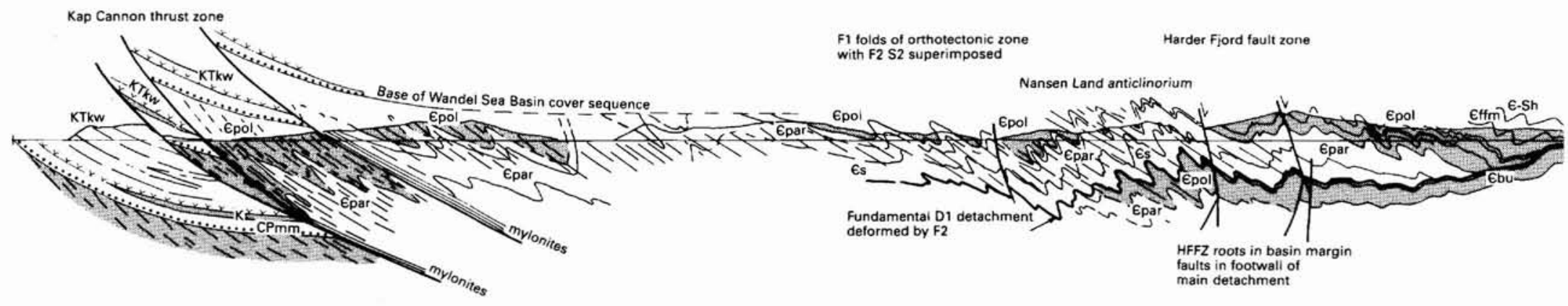

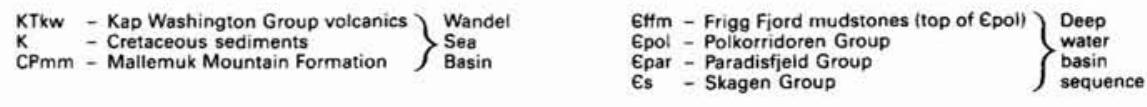

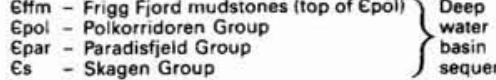

$\left.\begin{array}{l}\text { €.Sh - Slope tacies } \\ \in 0=\text { Platform carbonates } \\ \text { €bu = Buen Formation } \\ \text { Gpo - Portfield Formation }\end{array}\right\} \begin{aligned} & \text { Platform } \\ & - \text { slope } \\ & \text { sequence }\end{aligned}$ $\left.\begin{array}{l}\text { Sik - Lauge Koch Land Formation } \\ \text { Swi - Wulif Land Formation } \\ \text { Sm - Merqujōa Formation }\end{array}\right\} \begin{aligned} & \text { Peary } \\ & \text { Land } \\ & \text { Group }\end{aligned}$

SOUTH
KAP BOPA

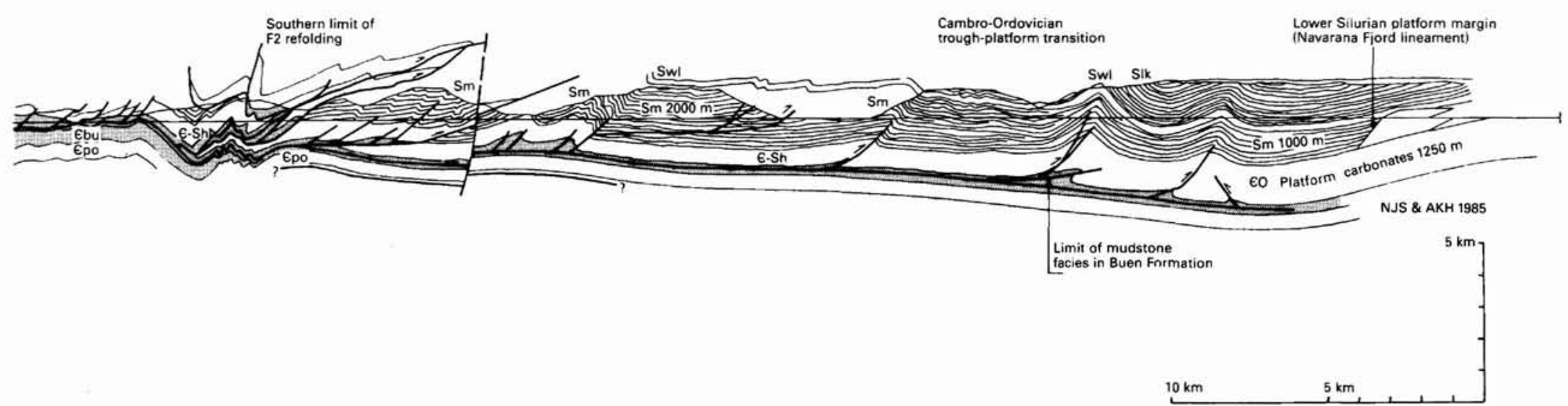

Fig. 66. North-south cross-section of the North Greenland fold belt. See Fig. 65 for the line of section. Most folds and thrusts shown are Ellesmerian (Devonian-Carboniferous) in age, but note that the Kap Cannon thrust zone at the northern end of the section is Tertiary. Modified after Soper \& Higgins (1987). 


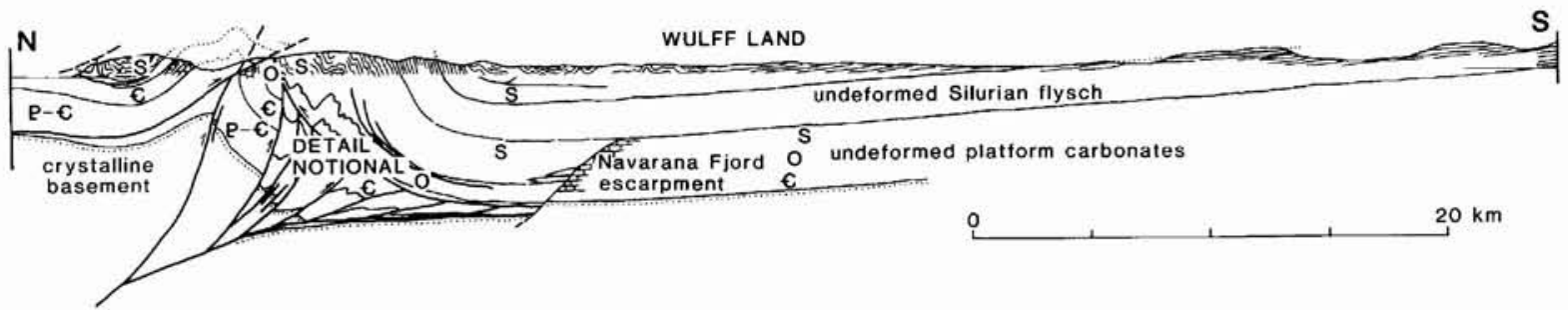

Fig. 67. North-south cross-section of the mountain front monocline in Wulff Land showing interpretation of the deep structure. After Higgins \& Soper (1989).

\section{The Ellesmerian Orogeny}

The mid-Palaeozoic Ellesmerian Orogeny, which brought sedimentation in the Franklinian Basin to a close, involved compression of the Early Cambrian latest Silurian trough sequence against the carbonate shelf which flanked it to the south. In the resulting Ellesmerian fold belts of both North Greenland and northern Ellesmere Island fold trends run E-W to NE-SW, broadly parallel to the main facies boundaries within the Franklinian Basin. Little is known of the geotectonic context of the Ellesmerian Orogeny, although it has usually been interpretated in terms of southward underthrusting of ocean floor against and beneath the continental block and Franklinian Basin (Trettin et al., 1972; Dawes \& Soper, 1973; Trettin \& Balkwill, 1979). However, the early Palaeozoic granitic plutonism and arc-type volcanism of northernmost Ellesmere Island (Pearya) formerly viewed as characteristic of an in situ magmatic arc are now viewed as elements of an exotic terrane (Trettin, 1987).

The region of North Greenland affected by Ellesmerian deformation is conventionally known as the North Greenland fold belt. Deformation is most intense in northern Peary Land (Johannes V. Jensen Land) where three phases of coaxial folding are recognised and metamorphic grade reaches low amphibolite facies (Dawes, 1976). Both deformation and metamorphism decrease southwards. Three distinct tectonic zones can be recognised (Fig. 65), spatially related to the geometry of the Franklinian Basin (Soper \& Higgins, 1987).

A southern thin-skinned fold and thrust zone coincides with a region which was transitional between the platform and trough for much of the Cambrian. It is approximately bounded to the south by the Navarana Fjord lineament, a pronounced mid-Ordovician to early Silurian platform escarpment the position of which was probably initially controlled by faulting (see previous discussion). Deformation is of classic fold and thrust style with flexural slip folds located above thrust ramps. Folds verge southwards; thrusts dip at gentle to moderate inclinations northwards and have a southwards sense of displacement (Fig. 65). Westwards from the line of section of Fig. 66 the most conspicuous feature of the fold and thrust zone is a major mountain front monocline which attains an amplitude of some $7 \mathrm{~km}$ at its greatest development in Wulff Land. Attempts to model the deep structure beneath the monocline by Soper \& Higgins (1990) show that it cannot be interpreted as entirely thin-skinned and that crystalline basement must be involved. In their model (Fig. 67) an early Palaeozoic extensional basement ramp is envisaged as having been reactivated during the Ellesmerian Orogeny.

The divergence and imbricate zone (Fig. 65) corresponds to the tract across which the vergence of folds changes from south to north. It also coincides with a pronounced change in the stratigraphic level of rocks exposed at the surface. To the north, in the orthotectonic zone on the site of the trough, Lower Cambrian rocks are exposed. To the south, across the fold and thrust zone and adjacent parts of the undeformed platform, Silurian rocks are exposed except where older rocks are brought to the surface in anticlinal fold cores and thrust sheets. The divergence zone widens eastwards, where it is characterised by imbricate thrusts with curvilinear traces which verge to the west and south (Pedersen, 1986).

The orthotectonic zone is developed on the site of the trough proper, with its thick fill of Lower Cambrian carbonate and siliciclastic turbidites (Paradisfjeld Group and Polkorridoren Group). In the eastern part of the orthotectonic zone structures referable to three coaxial tectonic episodes (F1, F2 \& F3) are recognised. F1 folds are dominant in the south, where they are upright. To the north, F2 folds become superimposed on F1; these are consistently overturned northwards and develop a south-dipping axial plane fabric. Near the north coast, where $F 1$ and $F 2$ are isoclinal, $F 3$ folds are superimposed and the metamorphic grade rises to low amphibolite facies. In the western part of the orthotectonic zone in Nansen Land and adjacent islands the dominant structures are spectacular trains of $\mathrm{F} 1$ folds, upright or slightly northward verging (Fig. 13); F2 struc- 
tures are only weakly developed and $\mathrm{F} 3$ is absent here. A cross-section through the fold belt (Fig. 66) illustrates the relationships between the zones.

Following a period of erosion and peneplanation, the folded early Palaeozoic sediments of the Ellesmerian fold belts were overlain by Carboniferous to early Tertiary sediments and volcanics. In northern Ellesmere Island these sequences are referred to the Sverdrup Ba$\sin$, and in North Greenland to the Wandel Sea Basin (Stemmerik \& Håkansson, 1991; Håkansson et al., 1991).

Acknowledgements. We would like to thank our many colleagues and friends, fellow participants in the several stages of the North Greenland Project and its associated studies, for freely making available their results and observations. Project leader Niels Henriksen provided the organisational framework which allowed us easy access to North Greenland geology and the time to study it, albeit briefly. Hans P. Trettin (Geological Survey of Canada) is thanked for his guidance in connection with the preparation of an earlier manuscript (Higgins et al., in press), a contribution to the Decade of North American Geology programme, which formed the basis for the present paper. Birgitte Larsen is thanked for typing the original manuscript. Jette Halskov, Bodil Sikker Hansen and Bente Thomas are thanked for artwork, and Jakob Lautrup for photographic illustrations.

\section{References}

Armstrong, H. A. 1990: Conodonts from the Upper Ordovician - Lower Silurian carbonate platform of North Greenland. Bull. Grønlands geol. Unders. 159, 151 pp.

Armstrong, H. A. \& Lane, P. D. 1981: The un-named Silurian (?) dolomite formation, Børglum Elv, central Peary Land. Rapp. Gronlands geol. Unders. 106, 29-34.

Barnes, C. R. 1984: Early Ordovician eustatic events in Canada. In Bruton, D. L. (ed.) Aspects of the Ordovician System, 51-63. Oslo: Universitetsforlaget.

Bengaard, H.-J., Davis, N. C., Friderichsen, J. D. \& Higgins, A. K. 1987: Lithostratigraphy and structure of the North Greenland fold belt in Nansen Land. Rapp. Grønlands geol. Unders. 133, 99-106.

Bergström, J. \& Peel, J. S. 1988: Lower Cambrian trace fossils from northern Greenland. Rapp. Grønlands geol. Unders. 137, 43-53.

Bjerreskov, M. 1981: Silurian graptolites from Washington Land, western North Greenland. Bull. Gronlands geol. Unders. $142,58 \mathrm{pp}$.

Bjerreskov, M. 1986: Silurian graptolites from N Greenland. In Hughes, C. P. \& Rickards, R. B. (ed.) Palaeoecology and biostratigraphy of graptolites. Geol. Soc. Spec. Publ. 20, 181-189.

Bjerreskov, M. 1989: Ordovician graptolite biostratigraphy in North Greenland. Rapp. Gronlands geol. Unders. 144, $17-33$.
Brenchley, P. J. \& Newall, G. 1980: A facies analysis of Upper Ordovician regressive sequences in the Oslo region, Norway - a record of glacio-eustatic changes. Palaeogeo., Palaeoclim., Palaeoecol. 31, 1-38.

Bryant, I. D. \& Pickerill, R. K. 1990: Lower Cambrian trace fossils from the Buen Formation of central North Greenland: preliminary observations. Rapp. Gronlands geol. Unders. 147, 44-62.

Bryant, I. D. \& Smith, M. P. 1985: Lowermost Ordovician sandstones in central and western North Greenland. Rapp. Gronlands geol. Unders. 126, 25-30.

Bryant, 1. D. \& Smith, M. P. 1990: A composite tectoniceustatic origin for shelf sandstones at the Cambrian-Ordovician boundary in North Greenland. J. geol. Soc. Lond. 147, 795-809.

Christiansen, F. G. (ed.) 1989: Petroleum geology of North Greenland. Bull. Grønlands geol. Unders. 158, 92 pp.

Christiansen, F. G. 1990: A future Arctic exploration target: Lower Paleozoic in North Greenland. Oil \& Gas J. 88(7), 56-58.

Christie, R. L. 1967: Bache Peninsula, Ellesmere Island, Arctic Archipelago. Mem. geol. Surv. Can. 347, 63 pp.

Christie, R. L. \& Dawes, P. R. in press: Geographic and geologic exploration. In Trettin, H. P. (ed.) Innuitian Orogen and Arctic Platform; Canada and Greenland, Geology of Canada 3. Ottawa: Geol. Surv. Canada (also The geology of North America E, Boulder, Colorado: Geol. Soc. America).

Christic, R. L. \& Ineson, J. R. 1979: Precambrian-Silurian geology of the G. B. Schley Fjord region, eastern Peary Land, North Greenland. Rapp. Grønlands geol. Unders. 88, 63-71.

Christie, R. L. \& Peel, J. S. 1977: Cambrian-Silurian stratigraphy of Børglum Elv, Peary Land, eastern North Greenland. Rapp. Gronlands geol. Unders. 82, 48 pp.

Conway Morris, S. \& Peel, J. S. 1990: Articulated halkieriids from the Lower Cambrian of North Greenland. Nature 345, 802-805.

Davis, N. C. \& Higgins, A. K. 1987: Cambrian - Lower Silurian stratigraphy in the fold and thrust zone between northern Nyeboe Land and J. P. Koch Fjord, North Greenland. Rapp. Grønlands geol. Unders. 133, 91-98.

Dawes, P. R. 1971: The North Greenland fold belt and environs. Bull. geol. Soc. Denmark 20, 197-239.

Dawes, P. R. 1976: Precambrian to Tertiary of northern Greenland. In Watt, W. S. \& Escher, A. (ed.) Geology of Greenland, 248-303. Copenhagen: Geol. Surv. Greenland.

Dawes, P. R. 1987: Topographical and geological maps of Hall Land, North Greenland. Description of a computer-supported photogrammetrical research programme for production of new maps, and the Lower Palaeozoic and surficial geology. Bull. Grønlands geol. Unders. $155,88 \mathrm{pp}$.

Dawes, P. R. \& Christie, R. L. 1982: History of exploration and geology in the Nares Strait region. In Dawes, P. R. \& Kerr, J. W. (ed.) Nares Strait and the drift of Greenland: a conflict in plate tectonics. Meddr Gronland Geosci. 8, 19-36.

Dawes, P. R. \& Peel, J. S. 1981: The northern margin of Greenland from Baffin Bay to the Greenland Sea. In Nairn, A. E. M., Churkin, M. \& Stchli, F. G. (ed.) The ocean 
basins and margins 5, 201-264. New York: Plenum Publ. Corp.

Dawes, P. R. \& Peel, J. S. 1984: Biostratigraphic reconnaissance in the Lower Palaeozoic of western North Greenland. Rapp. Grønlands geol. Unders. 121, 19-51.

Dawes, P. R. \& Soper, N. J. 1973: Pre-Quaternary history of North Greenland. In Pitcher, M. G. (ed.) Arctic geology. Mem. Am. Ass. Petrol. Geol. 19, 117-134.

Escher, J. C. \& Larsen, P.-H. 1987: The buried western extension of the Navarana Fjord escarpment in central and western North Greenland. Rapp. Grønlands geol. Unders. 133, 81-89.

Fortey, R. A. 1984: Global earlier Ordovician transgressions and regressions and their biological implications. In Bruton, D. L. (ed.) Aspects of the Ordovician System, 37-50. Oslo: Universitetsforlaget.

Fortey, R. A. \& Peel, J. S. 1983: The anomalous bathyurid trilobite Ceratopeltis, and its homeomorphs. In Briggs, D. E. G. \& Lane, P. D. (ed.) Trilobites and other early arthropods. Spec. Pap. Palaeont. 30, 51-57.

Fortey, R. A. \& Peel, J. S. 1989: Stratigraphy and hystricurid trilobites of the Christian Elv Formation (Lower Ordovician) of western North Greenland. Rapp. Grønlands geol. Unders. 144, 5-15.

Fortey, R. A. \& Peel, J. S. 1990: Early Ordovician trilobites and molluscs from the Poulsen Cliff Formation, Washington Land, western North Greenland. Bull. geol. Soc. Denmark $38,11-32$

Fränkl, E. 1955: Rapport über die Durchquerung von Nord Peary Land (Nordgrönland) im Sommer 1953. Meddr Grønland 103(8), $61 \mathrm{pp}$.

Friderichsen, J. D. \& Bengaard, H.-J. 1985: The North Greenland fold belt in eastern Nansen Land. Rapp. Grønlands geol. Unders. 126, 69-78.

Friderichsen, J. D., Higgins, A. K., Hurst, J. M., Pedersen, S. A. S., Soper, N. J. \& Surlyk, F. 1982: Lithostratigraphic framework of the Upper Proterozoic and Lower Palaeozoic deep water clastic deposits of North Greenland. Rapp. Gronlands geol. Unders. 107, 20 pp.

Frykman, P. 1980: A sedimentological investigation of the carbonates at the base of the Brønlund Fjord Group (EarlyMiddle Cambrian), Peary Land, eastern North Greenland. Rapp. Grønland geol. Unders. 99, 51-55.

Fürsich, F. T. \& Hurst, J. M. 1980: Euryhalinity of Palaeozoic articulate brachiopods. Lethaia 13, 303-312.

Galloway, W. E. \& Hobday, D. K. 1983: Terrigenous clastic depositional systems. Applications to petroleum, coal, and uranium exploration, 423 pp. Berlin: Springer Verlag.

Grahn, Y. \& Nøhr-Hansen, H. 1989: Chitinozoans from Ordovician and Silurian shelf and slope sequences in North Greenland. Rapp. Grønlands geol. Unders. 144, 35-41.

Hâkansson, E., Heinberg, C. \& Stemmerik, L. 1991: Mesozoic and Cenozoic history of the Wandel Sea Basin area, North Greenland. Bull. Gronlands geol. Unders. 160 (this volume).

Henriksen, N. \& Higgins, A. K. 1991: The North Greenland Project. Bull. Grønlands geol. Unders. 160 (this volume).

Henriksen, N. \& Peel, J. S. 1976: Cambrian - Early Ordovician stratigraphy in south-western Washington Land, west- ern Greenland. Rapp. Grønlands geol. Unders. 80, 17-23.

Higgins, A. K. \& Soper, N. J. 1985: Cambrian - Lower Silurian slope and basin stratigraphy between northern Nyeboe Land and western Amundsen Land, North Greenland. Rapp. Grønlands geol. Unders. 126, 7986.

Higgins, A. K. \& Soper, N. J. 1989: Short Paper: Nares Strait was not a Cenozoic plate boundary. J. geol. Soc. Lond. 146 , 913-916.

Higgins, A. K., Friderichsen, J. D. \& Soper, N. J. 1981: The North Greenland fold belt between central Johannes V. Jensen Land and eastern Nansen Land. Rapp. Gronlands geol. Unders. 106, 35-45.

Higgins, A. K., Soper, N. J. \& Friderichsen, J. D. 1985: North Greenland fold belt in eastern North Greenland. In Gee, D. G. \& Sturt, B. A. (ed.) The Caledonide Orogen - Scandinavia and related areas, 1017-1029. London: John Wiley \& Son Ltd.

Higgins, A. K., Ineson, J. R., Pcel, J. S., Surlyk, F. \& Sønderholm, M. in press: Cambrian to Silurian basin development and sedimentation, North Greenland. In Trettin, H. P. (ed.) Innuitian Orogen and Arctic Platform; Canada and Greenland, Geology of Canada 3. Ottawa: Geol. Surv. Canada (also The geology of North America E, Boulder, Colorado: Geol. Soc. America).

Hurst, J. M. 1980a: Silurian stratigraphy and facies distribution in Washington Land and western Hall Land, North Greenland. Bull. Grønlands geol. Unders. 138, 95 pp.

Hurst, J. M. 1980b: Paleogeographic and stratigraphic differentiation of Silurian carbonate buildups and biostromes of North Greenland. Bull. Am. Ass. Petrol. Geol. 64 (4), $527-$ 548.

Hurst, J. M. 1984: Upper Ordovician and Silurian carbonate shelf stratigraphy, facies and evolution, eastern North Greenland. Bull. Grønlands geol. Unders. 148, 73 pp.

Hurst, J. M. \& Kerr, J. W. 1982: Upper Ordovician to Silurian facies patterns in eastern Ellesmere Island and western North Greenland and their bearing on the Nares Strait lineament. In Dawes, P. R. \& Kerr, J. W. (cd.) Nares Strait and the drift of Greenland: a conflict in plate tectonics. Meddr Gronland Geosci. 8, 137-145.

Hurst, J. M. \& Peel, J. S. 1979: Late Proterozoic(?) to Silurian stratigraphy of southern Wulff Land, North Greenland Rapp. Gronlands geol. Unders. 91, 37-56.

Hurst, J. M. \& Surlyk, F. 1982: Stratigraphy of the Silurian turbidite sequence of North Greenland. Bull. Grønlands geol. Unders. 145, $121 \mathrm{pp}$.

Hurst, J. M. \& Surlyk, F. 1983a: Depositional environments along a carbonate ramp to slope transition in the Silurian of Washington Land, North Greenland. Can. J. Earth Sci. 20, 473-499.

Hurst, J. M. \& Surlyk, F. 1983b: Initiation, evolution, and destruction of an early Paleozoic carbonate shelf, eastern North Greenland. J. Geol. 91, 671-691.

Hurst, J. M., McKerrow, W. S., Soper, N. J. \& Surlyk, F. 1983: The relationship between Caledonian nappe tectonics and Silurian turbidite deposition in North Greenland. $\boldsymbol{J}$. geol. Soc. Lond. 140, 123-132.

Ineson, J. R. 1980: Carbonate debris flows in the Cambrian of 
south-west Peary Land, eastern North Greenland. Rapp. Gronlands geol. Unders. 99, 43-49.

Ineson, J. R. 1985: The stratigraphy and sedimentology of the Brønlund Fjord and Tavsens Iskappe Groups (Cambrian) of Peary Land, eastern North Greenland. Unpubl. Ph.D. thesis, Univ. of Keele, U.K., 310 pp.

Ineson, J. R. 1988: Lithostratigraphy and depositional setting of the Holm Dal Formation (Middle Cambrian), central North Greenland. Meddr Gronland Geosci. 20, 9-21.

Ineson, J. R. \& Peel, J. S. 1980: Cambrian stratigraphy in Peary Land, eastern North Greenland. Rapp. Gronlands geol. Unders. 99, 33-42.

Ineson, J. R. \& Peel, J. S. 1987: Cambrian platform - outer shelf relationships in the Nordenskiöld Fjord region, central North Greenland. Rapp. Gronlands geol. Unders. 133, $13-26$.

Ineson, J. R. \& Peel, J. S. in prep.: Cambrian shelf stratigraphy of the Peary Land region, central North Greenland. Manuscript in preparation to Bull. Grønlands geol. Unders.

Ineson, J. R., Peel, J. S. \& Smith, M. P. 1986: The Sjælland Fjelde Formation: a new Ordovician formation from eastern North Greenland. Rapp. Grønlands geol. Unders. 132, 27-37.

Jepsen, H. F. 1971: The Precambrian, Eocambrian and early Palaeozoic stratigraphy of the Jørgen Brønlund Fjord area, Peary Land, North Greenland. Bull. Grønlands geol. Unders. 96, $42 \mathrm{pp}$.

Johnson, M. E., Rong, J.-Y. \& Yang, X.-C. 1985: Intercontinental correlation by sea-level events in the Early Silurian of North America and China (Yangtze Platform). Bull. geol. Soc. Am. 96, 1384-1397.

Lane, P. D. 1972: New trilobites from the Silurian of north-east Greenland. Palaeontology 15, 336-364.

Lane, P. D. 1979: Llandovery trilobites from Washington Land, North Greenland. Bull. Grønlands geol. Unders. 131, $37 \mathrm{pp}$.

Larsen, P.-H. \& Escher, J. C. 1985: The Silurian turbidite sequence of the Peary Land Group between Newman Bugt and Victoria Fjord, western North Greenland. Rapp. Grønlands geol. Unders. 126, 47-67.

Larsen, P.-H. \& Escher, J. C. 1987: Additions to the lithostratigraphy of the Peary Land Group (Silurian) in western and central North Greenland. Rapp. Grønlands geol. Unders. 133, 65-80.

Larsen, P.-H. \& Escher, J. C. 1991: Stratigraphic section through the Silurian turbidite sequence (Peary Land Group) in northern Nyeboe Land, North Greenland. Rapp. Gronlands geol. Unders. 151, 21 pp.

Long, D. G. F. 1989a: Kennedy Channel Formation: key to the early history of the Franklinian continental margin, central eastern Ellesmere Island, Arctic Canada. Can. J. Earth Sci. 26, 1147-1159.

Long, D. G. F. 1989b: Ella Bay Formation: Early Cambrian shelf differentation in the Franklinian basin, central eastern Ellesmere Island, Arctic Canada. Can. J. Earth Sci. 26, 2621-2635.

McKerrow, W. S. 1979: Ordovician and Silurian changes in sea level. Quart. J. geol. Soc. Lond. 136, 137-145.
McLean, R. A. 1977: Early Silurian (Late Llandovery) rugose corals from western North Greenland. Bull. Grønlands geol. Unders. 121, $46 \mathrm{pp}$.

Mitchum, R. M., Vail, P. R. \& Thompson, S. 1977: Seismic depositional sequence as a basic unit for stratigraphic analysis. In Payton, C. E. (ed.) Seismic stratigraphy - applications to hydrocarbon exploration. Mem. Am. Ass. Petrol. Geol. 26, 53-62.

Nøhr-Hansen, H. \& Koppelhus, E. B. 1988: Ordovician spores with trilete rays from Washington Land, North Greenland. Rev. Palaeobot. Palyn. 56, 305-311.

Norford, B. S. 1973: Lower Silurian species of the trilobite Scotoharpes from Canada and northwestern Greenland. Bull. geol. Surv. Can. 222, 9-33.

O'Connor, B. 1979: The Portfjeld Formation (?early Cambrian) of eastern North Greenland. Rapp. Gronlands geol. Unders. 88, 23-28.

Palmer, A. R. \& Peel, J. S. 1981: Dresbachian trilobites and stratigraphy of the Cass Fjord Formation, western North Greenland. Bull. Gronlands geol. Unders. 141, 46 pp.

Pedersen, S. A. S. 1986: A transverse, thin skinned, thrustfault belt in the Paleozoic North Greenland Fold Belt. Bull. geol. Soc. Am. 97, 1442-1455.

Peel, J. S. 1979 (ed.): Lower Palaeozoic stratigraphy and palaeontology: shorter contributions. Rapp. Grønlands geol. Unders. 91, 132 pp.

Peel, J. S. 1980 (ed.): Palaeontology and stratigraphy of Greenland: shorter contributions. Rapp. Grønlands geol. Unders. 101, $68 \mathrm{pp}$.

Peel, J. S. 1982a: The Lower Paleozoic of Greenland. In Embry, A. F. \& Balkwill, R. (ed.) Arctic geology and geophysics. Mem. Can. Soc. Petrol. Geol. 8, 309-330.

Peel, J. S. 1982b: Palaeontology of Greenland: short contributions. Rapp. Gronlands geol. Unders. 108, $91 \mathrm{pp}$.

Peel, J. S. 1982c: The age of the Tavsens Iskappe Group, central North Greenland. Rapp. Gronlands geol. Unders. 108, 30 (only).

Peel, J. S. 1985: Cambrian-Silurian platform stratigraphy of eastern North Greenland. In Gee, D. G. \& Sturt, B. A. (ed.) The Caledonide Orogen - Scandinavia and related areas, 1077-1094. London: John Wiley \& Sons Ltd.

Peel, J. S. 1986 (ed.): North Greenland Lower Palaeozoic palaeontology and stratigraphy: short contributions. Rapp. Grønlands geol. Unders. 132, 123 pp.

Peel, J. S. 1988a (ed.): Stratigraphy and palacontology of the Holm Dal Formation (late Middle Cambrian), central North Greenland. Meddr Grønland Geosci. 20, 168 pp.

Peel, J. S. 1988b (ed.): Cambrian-Jurassic fossils, trace fossils and stratigraphy from Greenland. Rapp. Gronlands geol. Unders. 137, 159 pp.

Peel, J. S. 1988c: Spirellus and related helically coiled microfossils (cyanobacteria) from the Lower Cambrian of North Greenland. Rapp. Grønlands geol. Unders. 137, 5-32.

Peel, J. S. (ed.) 1990: Lower Cambrian trace fossils from Greenland. Rapp. Grønlands geol. Unders. 147, 62 pp.

Pcel, J. S. \& Christie, R. L. 1982: Cambrian-Ordovician platform stratigraphy: correlations around Kane Basin. In Dawes, P. R. \& Kerr, J. W. (ed.) Nares Strait and the drift 
of Greenland: a conflict in plate tectonics. Meddr Grønland Geosci. 8, 117-135.

Peel, J. S. \& Cowie, J. W. 1979: New names for Ordovician formations in Greenland. Rapp. Grønlands geol. Unders. 91, 117-124.

Peel, J. S. \& Higgins, A. K. 1980: Fossils from the Paradisfjeld Group, North Greenland fold belt. Rapp. Gronlands geol. Unders. 101, 28 (only).

Peel, J. S. \& Smith, M. P. 1988: The Wandel Valley Formation (Early - Middle Ordovician) of North Greenland and its correlatives. Rapp. Grønlands geol. Unders. 137, 61-92.

Peel, J. S. \& Wright, S. C. 1985: Cambrian platform stratigraphy in the Warming Land - Freuchen Land region, North Greenland. Rapp. Gronlands geol. Unders. 126, 17-24.

Peel, J. S., Ineson, J. R., Lane, P. D. \& Armstrong, H. A. 1981: Lower Palaeozoic stratigraphy around Danmark Fjord, eastern North Greenland. Rapp. Grønlands geol. Unders. 106, 21-27.

Peel, J. S., Dawes, P. R., Collinson, J. D. \& Christie, R. L. 1982: Proterozoic - basal Cambrian stratigraphy across Nares Strait: correlation between Inglefield Land and Bache Peninsula. In Dawes, P. R. \& Kerr, J. W. (ed.) Nares Strait and the drift of Greenland: a conflict in plate tectonics. Meddr Grønland Geosci. 8, 105-115.

Pickerill, R. K., Hurst, J. M. \& Surlyk, F. 1982: Notes on Lower Palaeozoic flysch trace fossils from Hall Land and Peary Land, North Greenland. Rapp. Grønlands geol. Unders. 108, 25-29.

Poulsen, C. 1927: The Cambrian, Ozarkian and Canadian faunas of Northwest Greenland. Meddr Gronland 70(1),2, 233 343.

Poulsen, C. 1934: The Silurian faunas of North Greenland. I. The fauna of the Cape Schuchert Formation. Meddr Gronland 72(2), 1, $46 \mathrm{pp}$.

Poulsen, C. 1941: The Silurian faunas of the Offley Island Formation. I. Coelenterata. Meddr Grønland 72(2),2, 28 pp.

Poulsen, C. 1943: The Silurian faunas of the Offley Island Formation. II. Brachiopoda. Meddr Grønland 72(2),3, 60 pp.

Poulsen, C. 1958: Contributions to the palaeontology of the Lower Cambrian Wulff River Formation. Meddr Grønland 162(2), $25 \mathrm{pp}$.

Poulsen, C. 1974: Silurian Pelecypoda, Monoplacophora, and Gastropoda from the reefy facies of the Offley Island Formation of Washington Land and Offley Island. Northwest Greenland. Biol. Skr. 20 (7), 14 pp.

Poulsen, V. 1964: Contributions to the Lower and Middle Cambrian paleontology and stratigraphy of Northwest Greenland. Meddr Gronland 164(6), 105 pp.

Poulsen, V. 1969: An Atlantic Middle Cambrian fauna from North Greenland. Lethaia 2, 1-14.

Poulsen, V. 1974: Olenellacean trilobites from eastern North Greenland. Bull. geol. Soc. Denmark 23, 79-101.

Robison, R. A. 1984: Cambrian Agnostida of North America and Greenland. Part I, Ptychagnostidae. Univ. Kansas Paleont. Contr. 109, $59 \mathrm{pp}$.

Robison, R. A. 1988: Trilobites of the Holm Dal Formation (late Middle Cambrian), central North Greenland. Meddr Grønland Geosci. 20, 23-103.

Schlager, W. 1981: The paradox of drowned reefs and carbonate platforms. Bull. geol. Soc. Am. 92, 197-211.

Smith, M. P., Sønderholm, M. \& Tull, S. J. 1989: The Morris Bugt Group (Middle Ordovician - Silurian) of North Greenland and its correlatives. Rapp. Gronlands geol. Unders. $143,5-20$.

Smith, M. P. in press: Early Ordovician conodonts of East and North Greenland. Meddr Grønland Geosci.

Sønderholm, M. \& Due, P. H. 1985: Lower and Middle Ordovician platform carbonate lithostratigraphy of Warming Land, Wulff Land and Nares Land, North Greenland. Rapp. Gronlands geol. Unders. 126, 31-46.

Sønderholm, M. \& Harland, T. L. 1989a: Latest Ordovician earliest Silurian carbonate mounds, western North Greenland. In Geldsetzter, H. H. J., James, N. P. \& Tebbutt, G. E. (ed.) Reefs, Canada and adjacent area. Mem. Can. Soc. Petrol. Geol. 13, 241-243.

Sønderholm, M. \& Harland, T. L. 1989b: Franklinian reef belt, Silurian, North Greenland. In Geldsetzter, H. H. J., James, N. P. \& Tebbutt, G. E. (ed.) Reefs, Canada and adjacent area. Mem. Can. Soc. Petrol. Geol. 13, 356-366.

Sønderholm, M. \& Harland, T. L. in prep.: The Late Ordovician - Silurian carbonate shelf in North Greenland: depositional evolution and lithostratigraphy of the upper Morris Bugt Group and the Washington Land Group. Manuscript in preparation to Bull. Grønlands geol. Unders.

Sønderholm, M. \& Jepsen, H. F. 1991: Proterozoic basins of North Greenland. Bull. Grønlands geol. Unders. 160 (this volume).

Sønderholm, M., Harland, T. L., Due, P. H., Jørgensen, L. N. \& Peel, J. S. 1987: Lithostratigraphy and depositional history of Upper Ordovician - Silurian shelf carbonates in central and western North Greenland. Rapp. Grønlands geol. Unders. 133, 27-40.

Soper, N. J. \& Higgins, A. K. 1985: Thin-skinned structures at the basin-shelf transition in North Greenland. Rapp. Grønlands geol. Unders. 126, 87-94.

Soper, N. J. \& Higgins, A. K. 1987: A shallow detachment beneath the North Greenland fold belt: implications for sedimentation and tectonics. Geol. Mag. 124, 441-450.

Soper, N. J. \& Higgins A. K. 1990: Models for the Ellesmerian mountain front in North Grenland: a basin margin inverted by basement uplift. J. Struct. Geol. 12, 83-97.

Soper, N. J., Higgins, A. K. \& Friderichsen, J. D. 1980: The North Greenland fold belt in eastern Johannes V. Jensen Land. Rapp. Gronlands geol. Unders. 99, 89-98.

Stemmerik, L. \& Håkansson, E. 1991: Carboniferous and Permian history of the Wandel Sea Basin, North Greenland. Bull. Gronlands geol. Unders. 160 (this volume).

Surlyk, F. 1982: Nares Strait and the down-current termination of the Silurian turbidite basin of North Greenland. In Dawes, P. R. \& Kerr, J. W. (ed.) Nares Strait and the drift of Greenland: a conflict in plate tectonics. Meddr Grønland Geosci. 8, 147-150.

Surlyk, F. \& Hurst, J. M. 1983: Evolution of the early Paleo- 
zoic deep-water basin of North Greenland - aulacogen or narrow ocean? Geology 11, 77-81.

Surlyk, F. \& Hurst, J. M. 1984: The evolution of the early Palaozoic deep-water basin of North Greenland. Bull. geol. Soc. Am. 95, 131-154.

Surlyk, F. \& Ineson, J. R. 1987a: Aspects of Franklinian shelf, slope and trough evolution and stratigraphy in North Greenland. Rapp. Grønlands geol. Unders. 133, 41-58.

Surlyk, F. \& Ineson, J. R. 1987b: The Navarana Fjord Member (new) - an Upper Llandovery platform derived carbonate conglomerate. Rapp. Grønlands geol. Unders. 133, 59-63.

Surlyk, F., Hurst, J. M. \& Bjerreskov, M. 1980: First agediagnostic fossils from the central part of the North Greenland foldbelt. Nature 286, 800-803.

Surlyk, F., Hurst, J. M. \& Pedersen, S. A. S. in prep.: Stratigraphy of the Cambro-Ordovician deep-water sediments of Peary Land, North Greenland. Manuscript in preparation to Bull. Grønlands geol. Unders.

Trettin, H. P. 1987: Pearya: a composite terrain with Caledonian affinities in northern Ellesmere Island. Can. J. Earth Sci. 24, 224-245.

Trettin, H. P. 1989: The arctic islands. In Bally, A. W. \& Palmer, A. R. (ed.) The geology of North America A, 349370. Boulder, Colorado: Geol. Soc. Amer.

Trettin, H. P. in press: Innuitian Orogen and Arctic Platform; Canada and Greenland. Geology of Canada 3. Ottawa: Geol. Surv. Can. (also The geology of North America E, Boulder, Colorado: Geol. Soc. Amer.).

Trettin, H. P. \& Balkwill, H. R. 1979: Contributions to the tectonic history of the Innuitian Province, Arctic Canada. Can. J. Earth Sci. 16, 748-769.

Trettin, H. P., Frisch, T. O., Sobczak, L. W., Weber, J. R.,
Law, L. K., Delaurier, I., Niblett, E. R. \& Whitham, K. 1972: The Innuitian Province. In Price R. A. \& Douglas R. J. W. (ed.) Variations in tectonic styles in Canada. Spec. Pap. geol. Ass. Can. 11, 83-179.

Troedsson, G. T. 1926: On the Middle and Upper Ordovician faunas of northern Greenland. I. Cephalopods. Meddr Grønland 71, 157 pp.

Troedsson, G. T. 1928: On the Middle and Upper Ordovician faunas of northern Greenland. II. Meddr Gronland 72(1),1, $197 \mathrm{pp}$.

Troelsen, J. C. 1949: Contributions to the geology of the area round Jørgen Brønlunds Fjord, Peary Land, North Greenland. Meddr Gronland 149(2), 29 pp.

Troelsen, J. C. 1950: Contributions to the geology of Northwest Greenland, Ellesmere Island and Axel Heiberg Island. Meddr Grønland 149(7), 86 pp.

Vail, P. R., Mitchum, R. M., Todd, R. G., Widmier, J. M., Thompson, S. Sangree, J. B., Bubb, J. N. \& Hatlelid, W. G. 1977: Seismic stratigraphy and global changes of sea level. In Payton, C. E. (ed.) Seismic stratigraphy - applications to hydrocarbon exploration. Mem. Am. Ass. Petrol. Geol. 26, 49-212.

Van Wagoner, J. C., Posamentier, H. W., Mitchum, R. M., Vail, P. R., Sarg, J. F., Loutit, T. S. \& Hardenbol, J. 1988: An overview of the fundamentals of sequence stratigraphy and key definitions. In Wilgus, C. K., Hastings, B. S., Kendall, C. G. St. C., Posamentier, H. W., Ross. C. A. \& Van Wagoner, J. C. (ed.) Sea-level changes: an integrated approach. Spec. Publ. Soc. Econ. Pal. Miner. 42, 39-45.

Wilson, J. L. 1975: Carbonate facies in geologic history, 471 pp. Berlin: Springer-Verlag. 

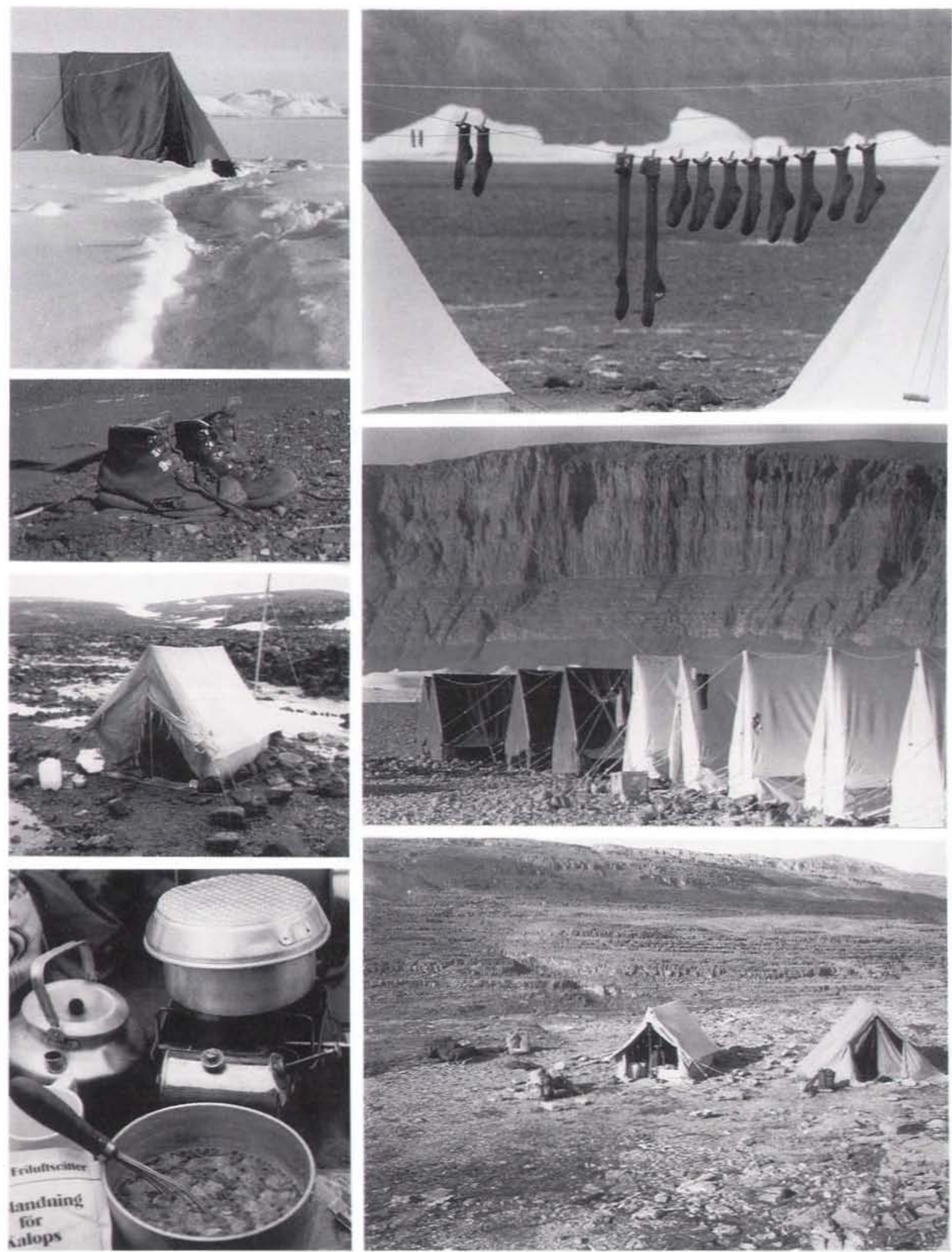

The North Greenland Project: camp life. 